\title{
The Impact of Unsaturated Zone Thickness on the Severity of Saltwater Intrusion in Coastal Aquifers from Overtopping
}

\author{
Dennis Jesse Carpinello \\ West Virginia University, djc0059@mix.wvu.edu
}

Follow this and additional works at: https://researchrepository.wvu.edu/etd

Part of the Hydrology Commons

\section{Recommended Citation}

Carpinello, Dennis Jesse, "The Impact of Unsaturated Zone Thickness on the Severity of Saltwater Intrusion in Coastal Aquifers from Overtopping" (2021). Graduate Theses, Dissertations, and Problem Reports. 8224.

https://researchrepository.wvu.edu/etd/8224

This Thesis is protected by copyright and/or related rights. It has been brought to you by the The Research Repository @ WVU with permission from the rights-holder(s). You are free to use this Thesis in any way that is permitted by the copyright and related rights legislation that applies to your use. For other uses you must obtain permission from the rights-holder(s) directly, unless additional rights are indicated by a Creative Commons license in the record and/ or on the work itself. This Thesis has been accepted for inclusion in WVU Graduate Theses, Dissertations, and Problem Reports collection by an authorized administrator of The Research Repository @ WVU. For more information, please contact researchrepository@mail.wvu.edu. 
The Impact of Unsaturated Zone Thickness on the Severity of Saltwater Intrusion in Coastal Aquifers from Overtopping

Dennis Jesse Carpinello

Follow this and additional works at: https://researchrepository.wvu.edu/etd

Part of the Hydrology Commons 


\title{
The Impact of Unsaturated Zone Thickness on the Severity of Saltwater Intrusion in Coastal Aquifers from Overtopping
}

\author{
Dennis Jesse Carpinello
}

Thesis submitted to the Eberly College of Arts and Sciences at West Virginia University in partial fulfillment of the requirements for the degree of Master of Science in Geology with concentration in Hydrogeology

Christopher J. Russoniello, Ph.D., Chair Aaron Maxwell, Ph.D.

James W. Heiss, Ph.D.

Department of Geology and Geography

Morgantown, West Virginia

2021

Keywords: Unsaturated Zone, Saltwater Intrusion, Storm-Surge Inundation, Overtopping, Coastal Aquifer

Copyright 2021 Dennis Jesse Carpinello 


\section{ABSTRACT \\ The Impact of Unsaturated Zone Thickness on the Severity of Saltwater Intrusion in Coastal Aquifers from Overtopping}

\section{Dennis Jesse Carpinello}

Storm-surge inundation and wave overwash, collectively overtopping, causes the land surface to be inundated with seawater, resulting in vertical infiltration of saline waters into underlying coastal aquifers, which can have severe consequences on freshwater resources. Unsaturated zone thickness plays an important role in determining the severity of saltwater contamination resulting from an overtopping event. This study uses numerical modeling to investigate vertical saltwater infiltration and salinization, and the subsequent aquifer recovery to overtopping events for coastal aquifers with different unsaturated zone thicknesses. Groundwater models were developed using the numerical code SUTRA to solve saturated-unsaturated, density-dependent groundwater flow and solute transport. Our results indicate that thicker unsaturated zones allowed a greater salt mass to infiltrate and salinized area to develop within a coastal aquifer following inundation. Models with thicker unsaturated zones also required an extended amount of time for the saline plume to flush through the fresh aquifer. Sensitivity analyses were also performed to investigate the impact of recharge, inundation time, and permeability. Our results found that high recharge rates resulted in less saline contamination and recovered to preinundation conditions more quickly. In addition, aquifer contamination and flushing times were relatively insensitive to inundation durations. Aquifers with higher permeability also received greater saline contamination but had shorter recovery times. The model results provide a generalized assessment of coastal aquifer susceptibility to an overtopping event and can inform managers of potential risks associated with overtopping as the frequency and severity of these events increase in response to a changing climate. 
Table of Contents

Title Page

i

Abstract

ii

Table of Contents

iii

Acknowledgments

1. Introduction

2. Methods

iv

2.1 Base Model

2.2 Sensitivity Analyses

2.2.1 Unsaturated Zone Thickness $\quad 14$

2.2.2 Recharge 14

2.2.3 Inundation Time 14

2.2.4 Permeability $\quad 14$

3. Results

$\begin{array}{lr}\text { 3.1 Base Model } & 15\end{array}$

3.2 Sensitivity Analyses 18

3.2.1 Unsaturated Zone Thickness 18

$\begin{array}{ll}\text { 3.2.3 Recharge } & 23\end{array}$

3.2.3 Inundation Time $\quad 26$

3.2.4 Permeability 30

4. Discussion $\quad 34$

4.1 Numerical Findings $\quad 34$

4.1.1 Unsaturated Zone Thickness $\quad 34$

$\begin{array}{ll}4.2 \text { Recharge } & 38\end{array}$

4.3 Inundation Time 41

4.4 Permeability 44

4.2 Model Assumptions $\quad 47$

4.3 Suggestions for Future Work 48

4.4 Societal Impacts $\quad 49$

5. Conclusions

6. References 53

Appendix A: Figures $\quad 57$

Appendix B: Tables $\quad 66$ 


\section{Acknowledgements}

First and foremost, I would like to express the deepest and most sincere appreciation to my committee chair and advisor Dr. Christopher Russoniello, without whom this project would not have been possible. You provided me with the opportunity to attend graduate school at West Virginia University and opened the door for me to a future I never imagined possible. Your knowledge, guidance, and patience cannot be underestimated and are a testament to what a truly remarkable researcher, scientist, mentor, and friend you are. I am eternally grateful to have had the honor and privilege of working with you.

Second, I would like to extend my sincere thanks to the other members of my committee, Dr. Aaron Maxwell and Dr. James Heiss, for your contributions to this project. Your insightful feedback and constant support brought my work to a higher level. I am grateful to have had the opportunity to work with each of you on this project. I would also like to thank the West Virginia University Department of Geology and Geography for providing the tools and facilities that allowed me to complete this project.

Finally, I could not have completed this project without the support of my family and friends. To my parents, Dennis and Denise, you were always there with tremendous encouragement and unparalleled support. You believed in me, even when I did not believe in myself. To my significant other, Cortney, you've always had incredible patience and understanding with me in pursuit on my graduate degree. You've been my constant over the last two years, and I could not be more grateful to have you in my life. Although words can never fully describe how appreciative I am for everything each of you have done for me, I guess "Thank you" and "I love you" will have to suffice. 


\section{Introduction}

Fresh groundwater in coastal aquifers is a vital water source for millions of people worldwide living along the coast. Globally, greater than $60 \%$ of the world's population reside within $100 \mathrm{~km}$ of a coastline (Yang et al., 2013). In the United States, approximately $40 \%$ of the population live within coastal counties, seeing an increase of 34.8 million people from 1970-2010 (NOAA, 2015). Coastal regions feature a population density nearly three times that of the global average (Small and Nicholls, 2003; Klassen and Allen, 2017). As the population along the coasts continues to increase, so too does the demand for fresh groundwater (Anderson, 2002). Fresh groundwater along these densely populated coastlines is not just crucial for domestic usage, but for agricultural and industrial purposes as well (Yang et al., 2015; Huizer et al., 2017; Elsayed and Oumeraci, 2018). Despite the influx of people to the coasts and the potential for overutilization of the fresh groundwater resources (Elsayed and Oumeraci, 2018), perhaps the greatest threat to unconfined coastal aquifers worldwide is saltwater intrusion (Liu and Tokunaga, 2019). Although fresh groundwater availability in coastal aquifers is mostly attributed to groundwater extraction and sea-level rise (Huizer et al., 2017), water quality in coastal aquifers has become increasingly vulnerable to salinization caused by the effects of coastal storms. The frequency and intensity of severe coastal storms is expected to rise in the future due to a changing climate (IPCC, 2012), which will lead to more extreme storm surges that negatively impact densely populated coastal regions and the coastal aquifers which they rely upon (Anderson, 2002; Chui and Terry, 2013; Yang et al., 2013, 2015, 2016; Cardenas et al., 2015; Giambastiani et al., 2017; Gingerich et al., 2017; Huizer et al., 2017; Mahmoodzadeh and Karamouz, 2017; Xiao et al., 2018). Continued population growth and the predicted increase of storm frequency and severity strengthen the importance of protecting our highly vulnerable unconfined coastal aquifers.

Storm surge has four distinct phases: 1) sea-level rise, 2) overwash resulting from the storm surge, 3) a return to pre-storm sea level, and 4) aquifer recovery (Yang et al., 2013). The temporary sea-level rise occurs as storms approach coastlines and offshore winds and low atmospheric pressure cause a local sea-level rise and increased wave energy (Terry, 2007; Chui and Terry, 2012). Wave overwash occurs as this increased wave energy drives already high seas across the land surface and beyond berms or coastal boundaries (Holding and Allen, 2015; 
Alsumaiei and Bailey, 2018), and results in temporary inundation of the land surface (Anderson, 2002; Illangasekare et al., 2006; Terry and Chui, 2012; Holding and Allen, 2015; Giambastinani et al., 2017; Alsumaiei and Bailey, 2018). For this study, wave overwash and storm surge inundation will be collectively referred to as overtopping (Figure 1). Overtopping causes the land surface to be inundated with seawater, which can result in vertical infiltration of saline waters into underlying coastal aquifers, especially if those aquifers are not fully saturated (Illangasekare et al., 2006; Klassen and Allen, 2007; Holding and Allen, 2015; Huizer et al., 2017; Elsayed and Oumeraci, 2018; Mahmoodzadeh and Karamouz, 2019). The saline plume develops at the top of an unconfined coastal aquifer (Holding and Allen, 2015). The plume moves downward due to the density differences between the infiltrating saltwater and fresh groundwater already present (Gingerich et al., 2017), and mixes with underlying fresh waters resulting in increased salt mass in the unconfined coastal aquifer (Kovacs et al., 2017). Saltwater contamination reduces the water quality of the coastal aquifer that local populations rely on and has adverse impacts on coastal ecosystems (Elsayed and Oumeraci, 2018).

Once contaminated, unconfined coastal aquifers can take years to fully recover. On small or atoll islands, which are ring-shaped islands, islets, or coral reefs, full recovery of the freshwater lens due to saltwater intrusion and contamination from overtopping can take approximately 1 to 3 years (Illangasekare et al., 2006; Chui and Terry, 2012; Holding and Allen, 2015; Gingerich et al., 2017; Alsumaiei and Bailey, 2018). On larger islands or continents, coastal aquifer recovery can take even longer. On larger islands, full recovery can require at least 10 (Cardenas et al., 2015) to 15 years (Liu and Tokunaga, 2019) and even as much as 19 years (Holding and Allen, 2015), while continental coastal aquifers may require decades (Yang et al., 2013, 2015; Elsayed and Oumeraci, 2018; Xiao et al., 2018; Mahmoodzadeh and Karamouz, 2019). While many of these studies indicate that island size and the extent of inundation are important, there are several other factors also influence the contamination extent and recovery time following an overtopping event, including topography, aquifer properties, recharge rate, and unsaturated zone thickness. 


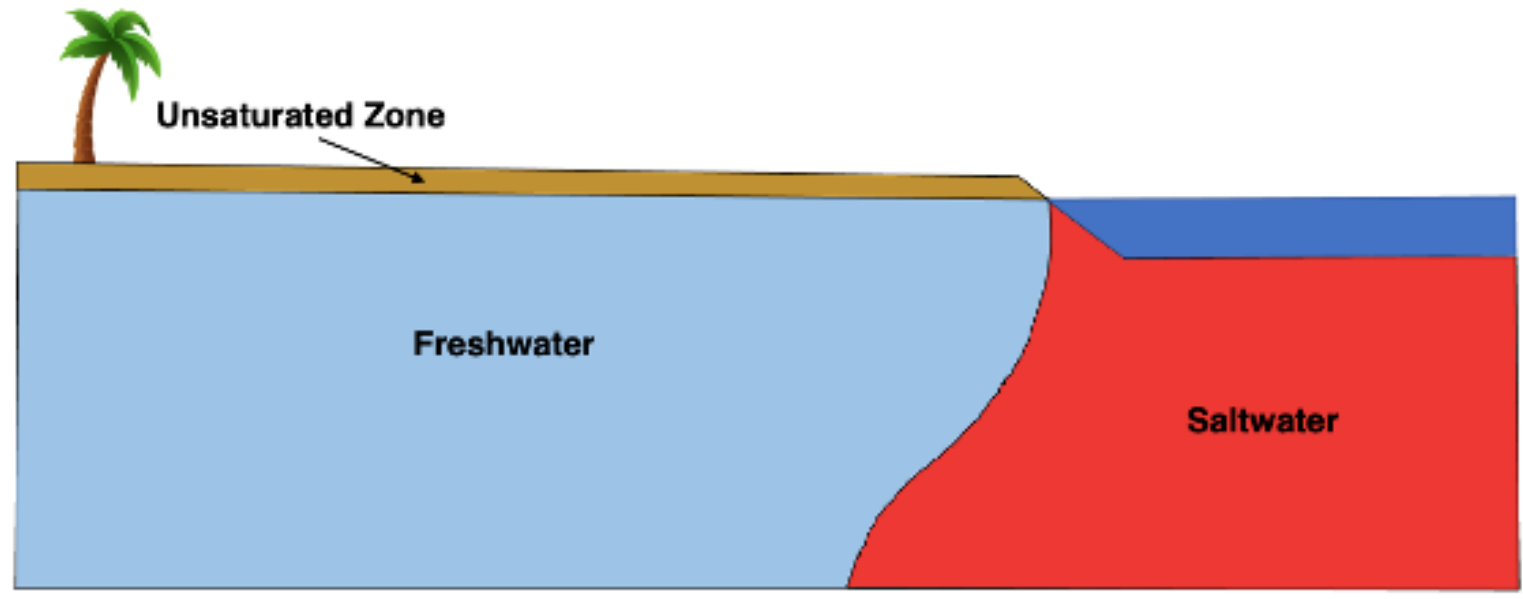

b

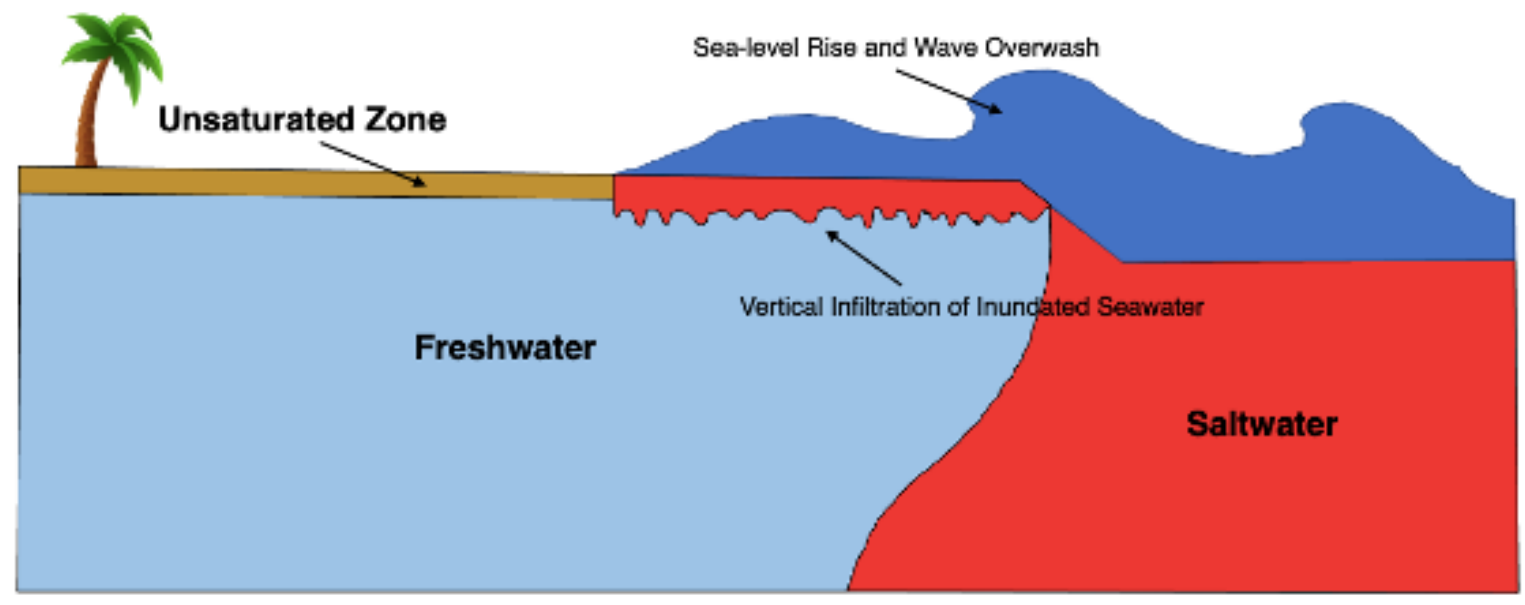

c

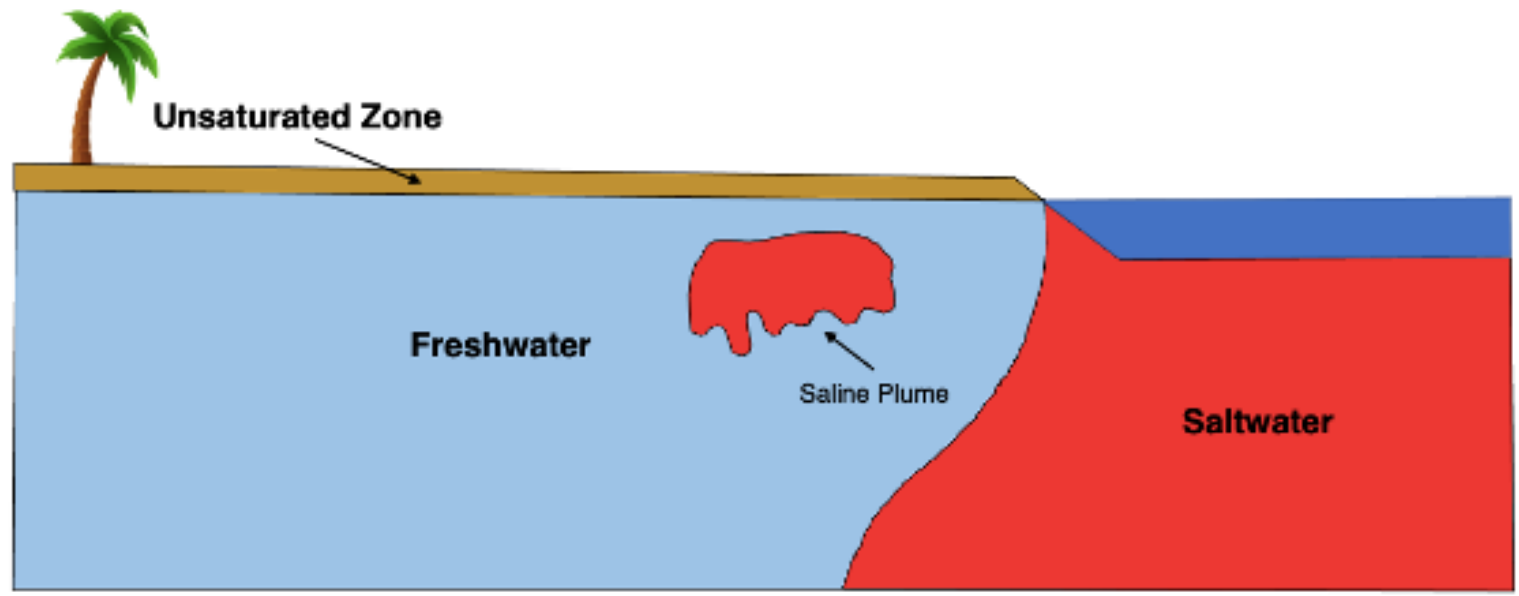

Figure 1: Conceptual model illustrating overtopping of a coastal aquifer system: (a) under normal, pre-storm conditions, (B) sea-level rise and wave overwash during an overtopping event, and (c) a return to pre-storm conditions.

Several studies have suggested the critical influence of the topography on the extent of overtopping. Yu et al. (2016) demonstrated that topographic controls on surface water hydrologic 
connectivity (e.g., control on surface water to move between the land and sea) that promote inundation during storm surge plays a crucial role in the volume of salinized water that can infiltrate an aquifer. Shore parallel topographic features, such as levees or dunes, generally act to prevent water's landward movement, which initially reduces overtopping impacts. However, if these features are breached, they can restrict the seaward draining of inundated seawater once sea level falls and cause depression storage on the barrier's landward side, serving as a constant source of seawater infiltration to the aquifer. Other features, such as a centralized atoll swamp, act in a similar manner (Chui and Terry, 2012, 2013). This increased surface ponding leads to an increase in the volume of salinized water available to infiltrate the aquifer, which can delay the aquifer's full recovery (Chui and Terry, 2012; Elsayed and Ouermaci, 2018; Yu et al., 2016). For this study, topographic features were not built into the model domain; a flat surface was used.

The hydrologic properties, including hydraulic conductivity and permeability, of the unsaturated zone and underlying coastal aquifer determine the extent of saltwater contamination occurring during overtopping events. Hydraulic conductivity $(K)$ is a measure of how easily water is transmitted through sediment (Fitts, 2002). Low $K$ within the unsaturated zone slows saline migration into the subsurface, limiting the quantity of saltwater that can infiltrate the underlying coastal aquifer upon inundation (Holding and Allen, 2015). On the other hand, high $K$ allows for faster infiltration of inundated saltwater into the unconfined coastal aquifer (Holding and Allen, 2015; Giambastiani et al., 2017). While higher $K$ values promote more severe contamination, they also allow an aquifer to recover more quickly due to increased advective movement (Illangasekare et al., 2006; Giambastiani et al., 2017; Gingerich et al., 2017; Liu and Tokunaga, 2019; Xiao et al., 2019). The isotropy of the aquifer is also a factor. Yang et al. (2018) concluded that the vulnerability of coastal aquifers increases with decreasing anisotropic conditions. However, anisotropic conditions yield differing results. Under anisotropic scenarios with low horizontal hydraulic conductivity $\left(\mathrm{K}_{\mathrm{x}}\right)$ and high vertical hydraulic conductivity $\left(\mathrm{K}_{\mathrm{z}}\right)$, an aquifer can be much more severely contaminated than under situations with high $\mathrm{K}_{\mathrm{x}}$ and low $\mathrm{K}_{\mathrm{z}}$ (Yang et al., 2018; Liu and Tokunaga, 2019). As demonstrated in the studies mentioned above, hydrologic properties play a critical role in the extent of saltwater contamination following an overtopping event. 
The fresh recharge rate, controlled mainly by precipitation, is the primary control on coastal aquifer recovery following an overtopping event (Illangasekare et al., 2006; Holding and Allen, 2015; Kovacs et al., 2017). High recharge results in elevated water tables as unsaturated pore spaces fill (Giambastiani et al., 2017), and the increased hydraulic gradients induce downward flushing and dispersion of saline contamination in the aquifer (Yu et al., 2017; Holding and Allen, 2015). High recharge rates drive quicker flushing and aquifer recovery (Yang et al., 2018; Liu and Tokunaga, 2019), whereas drier climates with lower recharge rates are likely to have more prolonged contamination following overtopping events (Illangasekare et al., 2006; Chui and Terry, 2012; Holding and Allen, 2015). For instance, a 2012 beach aquifer study following Hurricane Sandy observed that high precipitation resulted in an elevated water table, which increased the freshwater hydraulic gradient and led to a fresh discharge zone (Heiss and Michael, 2014). This likely reduced the volume of seawater that could infiltrate for a given amount of inundation. These studies have each identified the importance of recharge on aquifer recovery, yet few have characterized how differing recharge rates affect aquifer recovery on various unsaturated zone thicknesses.

Unsaturated zone thickness controls the volume of seawater that can infiltrate a coastal aquifer during an overtopping event, and thus controls the recovery time. During an overtopping event, the unsaturated zone fills with seawater from above, which remains in the aquifer as the sea returns to the pre-surge level (Chu and Terry, 2012; Holding and Allen, 2015). Therefore, the unsaturated zone thickness controls the volume of seawater that may infiltrate and contaminate during an overtopping event (Illangasekare et al., 2006). The unsaturated zone thickness is controlled by several factors, including recharge and $K$. Several studies, including Chui and Terry $(2012,2013)$ and Liu and Tokunaga (2019), found that a thicker unsaturated zone allows for more inundated seawater to infiltrate during an overtopping event, resulting in more severe, longer-lasting contamination. Infiltration of the seawater into the unsaturated zone occurs rapidly until achieving complete saturation, at which point the infiltration rate slows (Chui and Terry, 2012; Liu and Tokunaga, 2019). While these studies have noted the importance of the unsaturated zone during an overtopping event, none have explicitly investigated how the unsaturated zone thickness impacts the time required for the aquifer system to return to preinundation conditions. 
The primary objective of this study is to assess how the unsaturated zone thickness controls the vulnerability of coastal aquifers to seawater intrusion following an overtopping event by examining the effects of variable thicknesses of the unsaturated zone and recharge rates on the severity of vertical saltwater intrusion. To do this, groundwater models were constructed that represent a typical unconfined coastal aquifer system, with parameters that are typical of coastal aquifers or those used in previous studies. While the groundwater models simulate the process of overtopping, this study is intended to characterize the changes to the parameterization of the coastal aquifer system. More to the point, this study is focused on understanding how changing the parameters of the system impact the severity of contamination and recovery following an overtopping event. Results will be quantified by the amount of time required for natural flushing to restore the coastal aquifer to pre-inundation conditions and presented in subsequent figures and tables.

\section{Methods}

\subsection{Base Model}

Modeling overtopping on coastal aquifers requires the simulation of density-dependent flow and solute transport throughout the unsaturated zone and underlying coastal aquifer (Holding and Allen, 2015). All the simulations in this study were performed using SUTRA (Version 3.0), a finite-element groundwater model developed by the United States Geological Survey (USGS) that simulates saturated-unsaturated, density-dependent groundwater flow and solute transport (Provost and Voss, 2019). SUTRA was chosen over other modeling codes for its ability to model cross- sectional unsaturated, variable-density flow. An excellent freeware graphical user interface (GUI) is available for pre- and post-processing, ModelMuse, developed by the USGS, which was used in this study to process and run the simulations (Winston, 2009). Finally, SUTRA is very well documented, and the governing equations are well described in the SUTRA manual (Provost and Voss, 2019).

A base model was constructed (Figure 2) to simulate cross-sectional groundwater flow before, during, and after an overtopping event to a continental coastal aquifer. Population centers and infrastructure are generally concentrated within $1 \mathrm{~km}$ of coastlines (Ranjan et al., 2009), so 
modeling is focused on the coastal zone, where overtopping events are most likely to occur and are most impactful. From the left landward boundary moving right, the first $1000 \mathrm{~m}$ of the model domain are above sea level, the next $100 \mathrm{~m}$ are the beachface, which are partially covered by seawater - elevations above 0 mare not covered by seawater, while elevations below $0 \mathrm{~m}$ are and seawater completely covers the remaining $500 \mathrm{~m}$. The slope of the land surface (top, left) was assigned a constant linear slope of $0.1 \%$, similar to other studies (Elsayed and Ouermaci, 2018; Yang et al., 2018). The berm/beach face (top/middle) was assigned a 7\% slope, similar to Heiss et al. (2017). The ocean (top, right) was assigned no slope (horizontal) at an elevation of -6 $\mathrm{m}$ (AMSL). The model domain thickness varied between 41 and $30 \mathrm{~m}$ for the sensitivity analyses. The base case model was discretized into irregular elements (118,377), which allowed grid refinement in the areas of interest and coarsening in less dynamic regions. The spatial discretization varied from $1 \mathrm{~m}$ at the top 2-3 $\mathrm{m}$ of the model domain (parallel to the top of the model domain) and $3 \mathrm{~m}$ discretization to the remaining model domain. The base model domain depth was set $30 \mathrm{~m}$ below sea level. Aquifer parameters were assigned as homogenous across both unsaturated and saturated zones (Table 1).

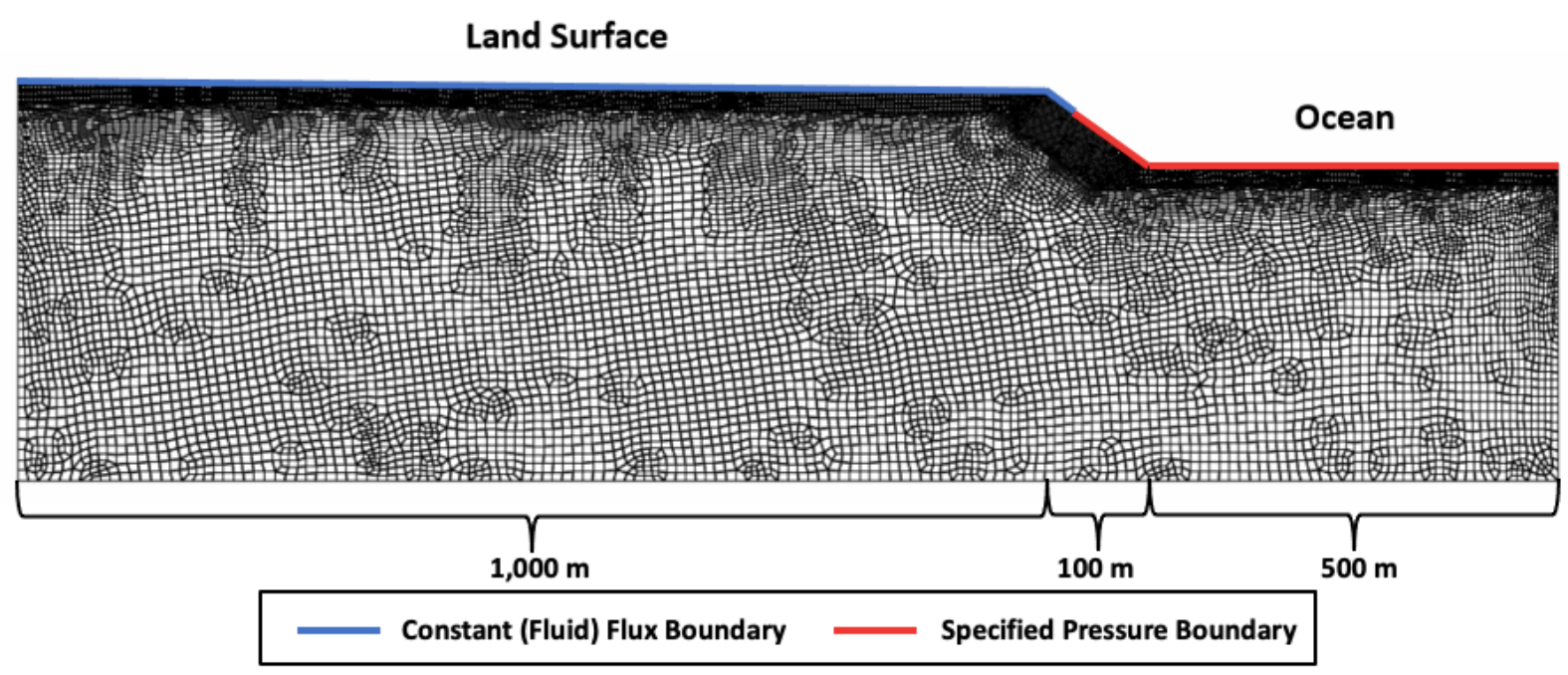

Figure 2: Model Domain (for Base Model)

Two boundary conditions were applied to the top of the base model domain: a constant flux boundary was applied to the land surface (terrestrial) with a concentration of $0 \mathrm{~kg}_{\text {salt }} / \mathrm{kg}_{\text {water, }}$ and a specified pressure boundary was applied to elements below sea level (seabed) with an influent concentration of seawater and an effluent concentration equal to the concentration modeled at the 
boundary node. Fluid flux applies an infiltration flux equally over the entirety of the boundary. The amount of recharge applied to the fluid flux boundary for each subaerial node was calculated as:

$$
R \frac{m}{y r} *(\text { ObjectIntersectLength } * 1 \mathrm{~m}) *\left(1,000 \frac{\mathrm{kg}}{\mathrm{m}^{3}}\right) *\left(\frac{1 \mathrm{yr}}{31,536,000 \mathrm{sec}}\right)
$$

where $R$ is the recharge in meters per year, ObjectIntersectLength returns the intersection length between an element and a 2-D projection of the object, $1 \mathrm{~m}$ represents the depth into the model domain, $1,000 \mathrm{~kg} / \mathrm{m}^{3}$ is the density of freshwater, and $1 \mathrm{yr} / 31,536,000 \mathrm{sec}$ is the conversion from years to seconds. No flow boundaries were assigned to the sides and bottom edge.

SUTRA is formulated to consider specified pressure, rather than head, in calculations; thus, the seaward boundary was represented as a specified-pressure boundary based upon the water table elevation. The water table elevation at the boundary was estimated as a function of pressure at the boundary-condition node, in which the pressure below the surface is assumed to be hydrostatic (Provost and Voss, 2019), using the equation:

$$
p(z)=p_{w t}+\rho g\left(z_{w t}-z\right)
$$

where $p(z)$ is the estimated pressure at a particular boundary-condition node $\left(\mathrm{kg} / \mathrm{m} \bullet \mathrm{s}^{2}\right), p_{\mathrm{wt}}$ is the pressure at the water table, $\rho$ is fluid density $\left(1.000 \mathrm{~g} / \mathrm{cm}^{3}\right.$ for freshwater; $1.025 \mathrm{~g} / \mathrm{cm}^{3}$ for seawater), $g$ is the acceleration of gravity $\left(9.8 \mathrm{~m} / \mathrm{s}^{2}\right), z_{\mathrm{wt}}$ is the elevation (m) at the water table, and $z$ is the elevation (m) of a given node (Provost and Voss, 2019). If the water table pressure is assigned to be zero, then $p_{\mathrm{wt}}$ can be eliminated from the equation.

$$
\boldsymbol{p}(\mathbf{z})=\boldsymbol{\rho g}\left(\mathbf{z}_{w t}-\mathbf{z}\right)
$$

If a node is below the water table $(p>0)$, the elevation-specific pressure at a given node is set with equation 3. However, if the node is at or above the water table, we assume that the node is dry ( $p=0$; equation 4$)$. 


$$
p(z)=\left\{\begin{array}{c}
z>0 ; \rho g\left(z_{w t}-z\right) \\
z \leq 0 ; 0
\end{array}\right.
$$

To apply the appropriate seawater density, equation 3 is modified to account for the seawater concentration. Therefore, the pressure applied to the specified pressure boundary for each simulation was completed using the equation:

$$
\left(\left(1000 \frac{\mathrm{kg}}{\mathrm{m}^{3}}+\left(700 \frac{\mathrm{kg} \text { water }}{\mathrm{kg} \text { salt }} * S W C\right)\right) * g *(S L-Y)\right)
$$

where $S W C$ is the concentration of saltwater $\left(0.0357 \mathrm{~kg}_{\text {salt }} / \mathrm{kg}_{\text {water }}\right)$ and $S L$ is the elevation of sea level, which is assigned a value of 0 (the elevation of mean sea level) prior to and following inundation and assigned a value equal to the instantaneous sea level during an overtopping event.

The properties of the unsaturated zone were assumed to be characterized by the van Genuchten model (van Genuchten, 1980; equations 6 and 7), which was programmed, by default, within SUTRA (Provost and Voss, 2019):

$$
\begin{aligned}
& S_{w}=\left\{\begin{array}{cl}
S_{r}+\left(1-S_{r}\right)\left[\frac{1}{\left[1+|a p|^{n}\right]}\right]^{m} & p<0 \\
1 & p \geq 0
\end{array}\right. \\
& k_{r}=\left[\frac{S_{w}-S_{r}}{1-S_{r}}\right]^{0.5}\left[1-\left\{1-\left(\frac{S_{w}-S_{r}}{1-S_{r}}\right)^{\frac{1}{m}}\right\}^{m}\right]^{2}
\end{aligned}
$$

where $\boldsymbol{S}_{\boldsymbol{w}}$ is the water saturation (dimensionless), $\boldsymbol{S}_{\boldsymbol{r}}$ is the residual saturation (SUTRA default: 0.3 , dimensionless), $\boldsymbol{a}$ is the fitting parameter (SUTRA default: $5 \times 10^{-5} \mathrm{~m} \cdot \mathrm{s}^{2} / \mathrm{kg}$ ), $\boldsymbol{p}$ is the capillary pressure $\left(\mathrm{kg} / \mathrm{m} \bullet \mathrm{s}^{2}\right), \boldsymbol{n}$ is the pore size distribution index (SUTRA default: 2, dimensionless), $\boldsymbol{m}$ is a fitting parameter ( $\boldsymbol{m}=1-1 / \boldsymbol{n}$, dimensionless), and $\boldsymbol{k}_{\boldsymbol{r}}$ is the relative permeability $\left(\mathrm{m}^{2}\right)$. In SUTRA, $\boldsymbol{a}$ is the inverse of pressure (equation 8): 


$$
a=\frac{1}{p}
$$

When substituting the default $\boldsymbol{a}$ value $\left(5 \times 10^{-5} \mathrm{~m} \cdot \mathrm{s}^{2} / \mathrm{kg}\right)$ into equation 8 , a capillary pressure of $20,000 \mathrm{~kg} / \mathrm{m} \cdot \mathrm{s}^{2}$ is obtained. The estimated capillary fringe, which is a layer above the water table where groundwater rises from capillary action, can be calculated using the equation:

$$
\boldsymbol{h}=\frac{p}{\rho \cdot g}
$$

where $\boldsymbol{h}$ is the estimated height of the capillary fringe, $\boldsymbol{p}$ is the capillary pressure $\left(\mathrm{kg} / \mathrm{m} \bullet \mathrm{s}^{2}\right), \boldsymbol{\rho}$ is the density of fresh water $\left(1,000 \mathrm{~kg} / \mathrm{m}^{3}\right)$, and $\boldsymbol{g}$ is the gravitational acceleration $\left(9.8 \mathrm{~m} / \mathrm{s}^{2}\right)$. When substituting the values for the capillary pressure, density of fresh water, and gravitational acceleration into equation 9, an estimated capillary fringe height of $2.04 \mathrm{~m}$ is obtained.

Overtopping events and the resulting infiltration and movement of saltwater through the coastal aquifer system, were modeled with three sequential simulations (Holding and Allen; 2015) that for each case (model sets hereafter):

- Initialization - development of the freshwater-saltwater interface to steady-state conditions

- Inundation - sea-level rise and surface inundation to simulate overtopping event

- Recovery - return to Initialization settings to simulate recovery of the coastal aquifer Each of these three simulations are required due to temporal discretization and boundary condition changes - all are transient. Heads and concentrations from the last timestep of the Initialization and Inundation periods were prescribed as the initial conditions of the Inundation and Recovery periods, respectively. Specified pressure and flux boundary conditions were applied as described above for both the Initialization and Recovery periods. In the Inundation period, as the beachface moved landwards and upwards with the rising sea level, boundaries were adjusted to extend the prescribed pressure boundary to all newly submerged nodes. 


\section{Model Parameters}

Permeability $\left(\mathrm{m}^{2}\right)$

Porosity

Longitudinal dispersivity (m)

Transverse dispersivity (m)

Sea water concentration $\left(\mathrm{kg}_{\text {salt }} / \mathrm{kg}_{\text {water }}\right)$

Fresh water concentration $\left(\mathrm{kg}_{\text {salt }} / \mathrm{kg}_{\text {water }}\right)$

Gravitational acceleration $\left(\mathrm{m} / \mathrm{s}^{2}\right)$

Fluid compressibility

Fluid diffusivity

Fluid viscosity $(\mathrm{kg} / \mathrm{ms})$

Land surface slope

Beach face slope
$1 \times 10^{-11}$

0.3

0.5

0.05

0.0357

0

9.8

0

0

0.001

$0.01 \%$

$7 \%$

Table 1: Model Parameters

The Initialization model is a transient simulation built to model the average long-term conditions prior to the overtopping event. The salinity concentration was set at $0.0357 \mathrm{~kg}_{\text {salt }} / \mathrm{kg}_{\text {water }}$ along the specified-pressure boundary (ocean) and $0 \mathrm{~kg}_{\text {salt }} / \mathrm{kg}_{\text {water }}$ along the fluid flux boundary (land surface) (e.g. Chui and Terry, 2012). The Initialization period simulation was run for a total of 600 years $(36,500$ time steps; initial time step $=259,200 \mathrm{~s}$; time step multiplier $=1.00)$ to ensure that steady state was achieved. Additional time, beyond what was initially allotted in the model input files, was required to reach steady state for the Initialization models. In this case, models were restarted with the results of the last time step from the previous Initialization period simulation and assigned as initial conditions.

The Inundation model is a transient simulation built to model contamination to the coastal aquifer system following an overtopping. The previously obtained Initialization solution was used as the initial conditions for the Inundation model. To simulate an overtopping event for the base case, the sea level will rise above the berm, which is at an elevation of $1 \mathrm{~m}$ above sea level. The water line extends $500 \mathrm{~m}$ inland, an additional $0.5 \mathrm{~m}$ height above sea level. Boundary conditions across the model domain surface were modified to reflect these changes; a prescribed pressure was applied to all submerged nodes based on the storm surge sea level (equation 5) that was inundated during the overtopping event. The inundation of the land surface lasts for 10 hours (147 time steps; initial time step $=60 \mathrm{~s}$; time step multiplier $=1.03)$, to match previous work (Chui and Terry, 2012; 2013) that simulated overtopping on atoll islands. The number of time 
steps, initial time step length, and time step multiplier value (in both the Inundation and Recovery models) were balanced to optimize run time and memory requirements, running the simulation for a long enough duration at a high-enough resolution to capture inundation and recovery processes.

The Recovery model was a transient simulation built to model recovery of the aquifer to preovertopping salinity levels. Boundary conditions were prescribed to match Initialization conditions. The Recovery model was run for approximately 86 years following inundation $(16,000$ time steps; initial time step $=360 \mathrm{~s}$; time step multiplier $=1.02)$ to monitor the coastal aquifer recovery following overtopping and salinization.

Models were post-processed and figures were generated with MATLAB (The Math Works, Inc., 2020). The SUTRA-Lab library (Zhang and Shen, 2015) was used to read model output files, with minor modifications made to increase stability and allow reading of the irregularly gridded model output. Once the model results were loaded and read, custom-built MATLAB scripts and functions were used to analyze the results. Concentration (C) and Saturation (S) data were interpolated from the model and irregular " $x, y$, value" output datasets were interpolated into a regularly-gridded domain. This was done to simplify post processing. Three-dimensional (x, $\mathrm{y}$, timestep) arrays for $\mathrm{C}$ and $\mathrm{S}$ were created and data were stored into a three-dimensional matrix.

The boundary between fresh and brackish/saline water was delineated based on the drinking water standard. The Environmental Protection Agency (EPA) created National Secondary Drinking Water Regulations (NSDWRs) that established non-mandatory water quality standards for contaminants not considered a risk to human well-being at the secondary maximum contaminant level (SMCLs), which aid public water services in managing drinking water for aesthetic purposes (Environmental Protection Agency, 2021). The EPA set a SMCL for total dissolved solids (TDS) at $500 \mathrm{mg} / \mathrm{L}(0.5 \mathrm{ppt})$, indicating that water with a concentration at or below 0.5 ppt is considered fresh (Poehls and Smith; 2011). However, a concentration of $0.6 \mathrm{ppt}$ was chosen as the trimming concentration, which provides a slightly more aggressive estimate of the time required to flush the saline contamination from the aquifer, as well as a baseline for comparison between models. The fresh/saline boundary was delineated at the last time-step of 
the Initialization model for each model set and was then used as a mask to remove the 'saline' aquifer from the Inundation and Recovery model results - all reported results are calculated from the 'fresh' aquifer unless otherwise noted.

Plots generated in MATLAB included the location of the freshwater-saltwater interface (using the clipping mask), changes in concentration and saturation during the Initialization period, total salt mass and area greater than the $0.6 \mathrm{ppt}$ standard during both the Inundation and Recovery periods, and a video depicting the mass centroid location during the Inundation and Recovery periods. Finally, the data was stored in a merged MATLAB 'structure' and saved for further MATLAB analysis, such as determining the salinized area within the aquifer and the salt mass added to the aquifer during inundation.

The salinized area reveals how large the saline plume is at any point in time during the Recovery period. Plots display the Maximum Salinized Area, or the largest size, in square meters $\left(\mathrm{m}^{2}\right)$, that the saline plume grows during inundation and aquifer recovery following inundation, providing an indication of the areal extent of the aquifer where salt concentration exceeds the $0.6 \mathrm{ppt}$ standard. The time at which the salinized area reduces to $10 \%$ of its maximum area was also determined, which allows for comparison of recovery times for each of the models.

The Salt Mass Added is a measure of how much additional salt mass is in the aquifer because of the overtopping event. Unlike the Maximum Salinized Area, the Salt Mass Added describes the total additional amount of salt within the aquifer at any point during inundation and aquifer recovery following inundation. Plots display the added salt mass, as well as the time required for the salt mass added during inundation to return to pre-inundation conditions, indicating complete flushing of the aquifer.

\subsection{Sensitivity Analyses}

To characterize how unsaturated zone thickness, recharge, inundation time, and permeability control salinization and recovery of a coastal aquifer following an overtopping event, each of the following parameters were varied across model sets as described below. 


\subsubsection{Unsaturated Zone Thickness}

Previous studies have shown that a thicker unsaturated zone allows for more inundated seawater to infiltrate during the overtopping event, resulting in more severe, longer-lasting contamination (Chui and Terry, 2012, 2013; Liu and Tokunaga, 2019). To quantify the impact of unsaturated zone thickness on the severity of contamination to a coastal aquifer resulting from an overtopping event, additional model domains were constructed with terrestrial land surfaces that were elevated compared to the base model (creating artificially thicker unsaturated zones), while mean sea level was kept constant. The three new model domains were assigned terrestrial land surface elevations that were $1.0 \mathrm{~m}$ (base model $+1 \mathrm{~m}$ ), $2.0 \mathrm{~m}$ (base model $+2 \mathrm{~m}$ ), and $3.0 \mathrm{~m}$ (base model $+3 \mathrm{~m}$ ) greater than the base model. While the slope of the terrestrial land surface $(0.1 \%)$ and beachface $(7 \%)$ were consistent across all models, the location of the slope break between the terrestrial land surface and beachface was moved further inland in models with thicker unsaturated zones, ensuring consistent geometry amongst model domains. The landward extent of inundation (500 m landward of the base model slope break) was consistent among all unsaturated zones assessed. Simulated unsaturated zones were approximately $1 \mathrm{~m}$ for the base model and were an additional 1-3 $\mathrm{m}$ in thickness across the remaining model domains.

\subsubsection{Recharge}

Additional sensitivity analyses were run to test the effect of fresh recharge rate on contamination severity and flushing time following an overtopping event. Five different recharge rates $(5 \mathrm{~cm} /$ year, $10 \mathrm{~cm} /$ year, $15 \mathrm{~cm} /$ year, $20 \mathrm{~cm} /$ year, and $25 \mathrm{~cm} /$ year $)$ were applied to each of the four domains (Base, $+1 \mathrm{~m},+2 \mathrm{~m}$, and $+3 \mathrm{~m}$ ). As in the base case, recharge rates were applied to all subaerial model nodes in all Initialization, Inundation, and Recovery periods.

\subsubsection{Inundation Time}

Further simulations were done to investigate the effect of inundation duration on the mass of saltwater infiltration and aquifer recovery following an overtopping event. These simulations applied inundation times of 10 hours (base case), 30 minutes, 1 hour, 5 hours, 20 hours, 50 hours, and 100 hours, on both the base and base $+2 \mathrm{~m}$ model domains.

\subsubsection{Permeability}


The impact of permeability was also assessed to determine the effect permeability has on the contamination and recovery of an aquifer. In addition to the base model, two additional simulations were run in which the permeability of the entire model domain was set at $5.5 \times 10^{-12}$ $\mathrm{m}^{2}$, slightly lower than that of the base model, and $1.0 \times 10^{-12} \mathrm{~m}^{2}$, one full order of magnitude smaller than the base model.

All model domains and hydrologic parameters can be found in Appendix B.

\section{Results}

\subsection{Base Model}

The simulation results for the base model at various points in time are illustrated in Figure 3. A steady state, which reflects normal, pre-storm conditions, was achieved by the end of the 600year Initialization period (Figure 3a), where the volume of water and concentration stabilized. The simulations resulted in the formation of the freshwater-saltwater interface. The stable freshwater lens (masked as the area $<0.6 \mathrm{ppt}$ ) contained a total salt mass of $0.21 \mathrm{~kg}$.
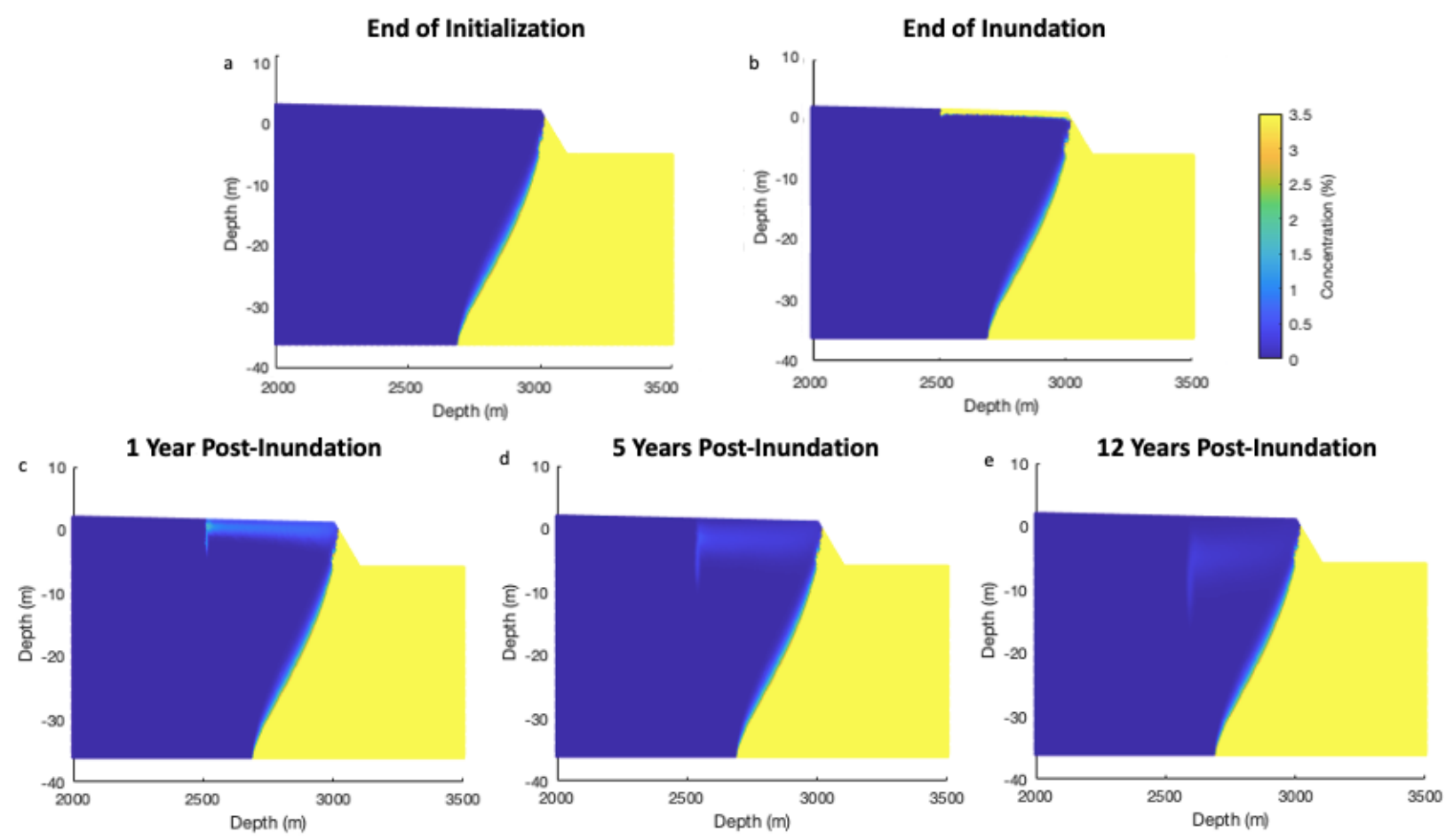

Figure 3: Base model at various points throughout the simulations: end of Initialization period (a), end of the Inundation period (b), one year into the Recovery period (c), 5 years into the Recovery period (d), and twelve years into Recovery period (e). A scale for concentration (in Percent Saline) is provided. 
During the Inundation period of the base model, high-density saline water entered the aquifer by infiltrating the unsaturated zone and created a density inversion, in which the dense saline water overlaid less dense freshwater (Figure 3b). At the landward extent of the boundary, inundated seawater flowed horizontally and began to fill the unsaturated zone landward of the inundation extent. The aquifer became saturated beneath the flooded (Specified Pressure) nodes along the land surface after the onset of inundation, resulting in an increase of $202.8 \mathrm{~m}^{2}$ saturated area in the fresh aquifer at the end of the 10-hour Inundation period (Figure 4a, red line). Additionally, $0.96 \mathrm{~kg}$ of salt mass had been added to the freshwater aquifer by the end of the 10-hour Inundation period (Figure 4a, blue line).

During the Recovery period of the base model, the plume percolated downward through the aquifer, especially at the landward extent of the plume (Figure 3c), and moved seaward, dispersing, and discharging across the saline interface from the fresh aquifer into the saline aquifer. The plume exhibited fingering due to the density inversion between the freshwater and overlying saltwater, and the concentrated fingers dispersed and diluted as they sank through the fresh aquifer (Figure 3d). This diluted saline water eventually traveled horizontally toward the interface before flowing across the interface and out of the fresh lens (Figure 3e).

\section{Maximum Salinized Area and Added Salt Mass During Inundation and Recovery (Base Model)}
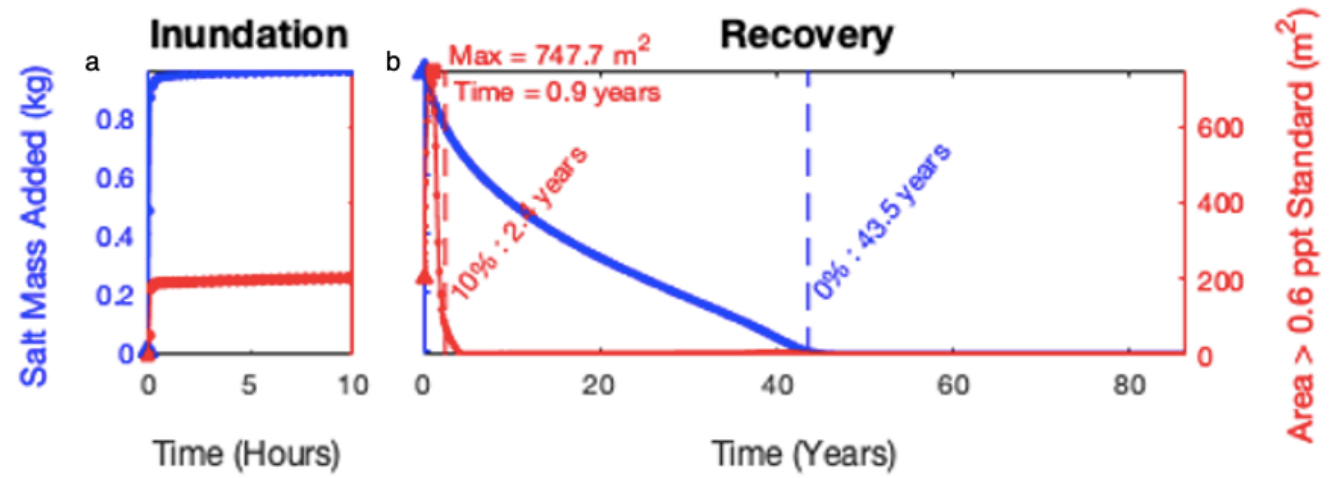

Figure 4: Changes to the salinized area greater than 0.6 ppt within the freshwater lens and salt mass added to the base model during the Inundation period simulation (a) and Recovery period simulation (b). 'Max' values indicate maximum salinized area and 'Time' values are when maximum salinized area occurs. '10\%' indicates the time at which the maximum salinized area is reduced by $90 \%$. '0\%' is the time that the salt mass added returns to pre-inundation conditions 
As the saline plume traveled through the aquifer, the initial highly-concentrated seawater dispersed into a lower-concentration, larger area plume before discharging from the fresh aquifer. The plume area exceeding the $0.6 \mathrm{ppt}$ standard (Figure $4 \mathrm{~b}$; solid red line) increased to a maximum of $747.7 \mathrm{~m}^{2}$ at 0.9 years post- inundation, which was $368.6 \%$ larger than the salinized area at the end of the Inundation period $\left(202.8 \mathrm{~m}^{2}\right)$. It took until 2.4 years into recovery before the contaminated area (Figure $4 \mathrm{~b}$; dashed red line) reduced to $10 \%$ of the maximum. The maximum mass of added salt within the aquifer $(0.96 \mathrm{~kg})$ occurred 2.7 days into the Recovery phase, whereafter the total salt mass within the freshwater aquifer decreased continuously throughout the simulation (Figure 4b; blue line). The salinized area decreased more quickly than the added salt mass, which declined the pre-inundation mass at 43.5 years post-inundation (Figure 4b, dashed blue line).

The centroid of the salt mass (Figure 5), which is the geometric center of the saline area, migrates through the aquifer and eventually reaches the interface. For the first five years postinundation, the mass centroid travelled vertically from a starting depth of $-2.14 \mathrm{~m}$ to a depth of $5.8 \mathrm{~m}$ as the dense inundated seawater sank within the aquifer. In addition, the mass centroid moved $28.6 \mathrm{~m}$ landward from the starting position as well. Over the next 25 years, the centroid path continues to move deeper in the aquifer, reaching a depth of $-13.255 \mathrm{~m}$ at 30 years postinundation. However, after five years post-inundation, the path of the mass centroid began to move seaward as the saline plume became less concentrated. Approximately 30 years into recovery, the centroid path rose while taking a more horizontal trajectory seaward, likely due to mixing with the interface. Forty years into the Recovery period, the centroid had risen to a depth of $-13.125 \mathrm{~m}$ but had moved $132 \mathrm{~m}$ seaward $(2,889.3 \mathrm{~m})$ from its farthest landward extent. Over the next ten years, the centroid, once again, began to drop within the aquifer, following the interface because the added salt mass within the fresh aquifer was restricted to the near-interface region - salt mass within the fresh aquifer were very low by 40 years post inundation (i.e. $<0.05$ $\mathrm{kg}$ ), so this is likely an artifact of the freshwater lens delineation from the saltwater clipping mask. The centroid did not move after 50 years post inundation indicating the system had returned to steady state. 


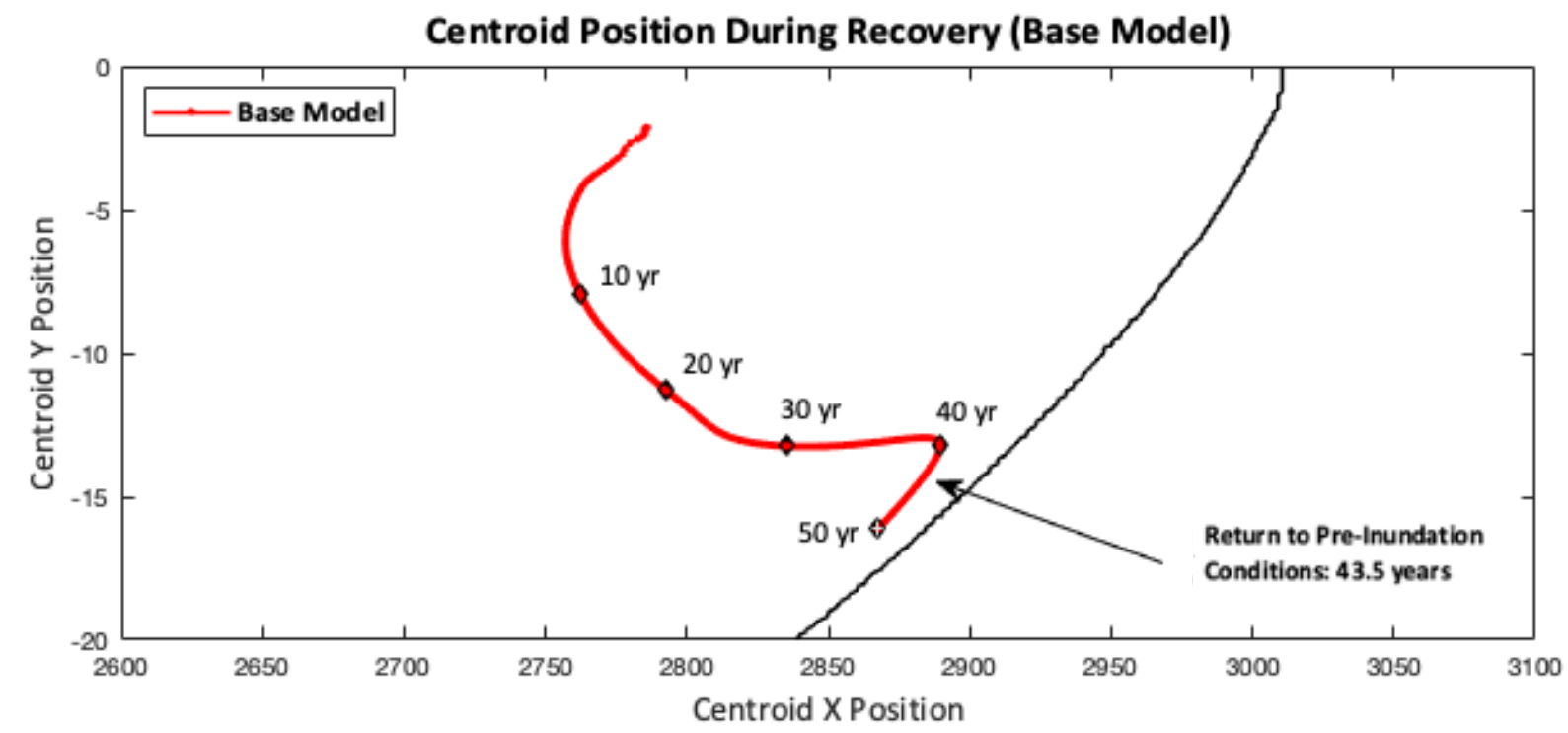

Figure 5: Path of mass centroid (red line) for the base model during aquifer recovery. Diamonds on the red line indicate the location of the mass centroid at 10-year intervals. The black line is the location of the freshwatersaltwater interface.

\subsection{Sensitivity Analyses}

The results sensitivity analysis simulations are compared base case results and discussed in the following paragraphs. In each set of simulations, one major parameter influencing the severity of contamination and the time for recovery was modified, as described in section 2.2.

\subsubsection{Unsaturated Zone Thickness}

Unsaturated zone thickness impacts both the salinized area and the post-inundation time required to flush the saline plume. The area greater than $0.6 \mathrm{ppt}$ increased as the unsaturated zone thickness of the model domain increased. The greatest maximum salinized area occurred in the model with the greatest unsaturated zone thickness (base model $+3 \mathrm{~m}$ ) (Figure 6d), which had a maximum salinized area of $7,410.7 \mathrm{~m}^{2}$ - nearly ten times higher than that of the base model (Figure 6a). The maximum salinized area was reached at 11.4 years post-inundation, which was more than 12.5 times longer than in the base model. The salinized area for this model declined to $10 \%$ of the maximum area 37.3 years after inundation, 15.5 times longer than the base model.

The added salt mass increased as the unsaturated zone thickness increased and, subsequently, had an impact on flushing time - times required to flush aquifers to pre-inundation conditions 
increased as the unsaturated zone thickness increased. The maximum added salt mass was reached within the first 50 days of the recovery period in all simulations (Figures 6, 7). However, the maximum added salt mass for the base model was reached in under two days - nearly 47 days quicker than models with increased unsaturated zone thickness. The base model also had 8.8 times less added mass than the model with an additional $2 \mathrm{~m}$ of unsaturated zone thickness, and more than 17 times less mass than the model with an additional $3 \mathrm{~m}$ of unsaturated zone thickness. Thicker unsaturated zones also resulted in greater times necessary to return to preinundation conditions for all models (Figure 6, dashed blue line). While the base model returned to pre-inundation conditions after 43.5 years, the model with an additional $3 \mathrm{~m}$ of unsaturated zone thickness needed more than 25 years longer to return to pre-inundation conditions. 

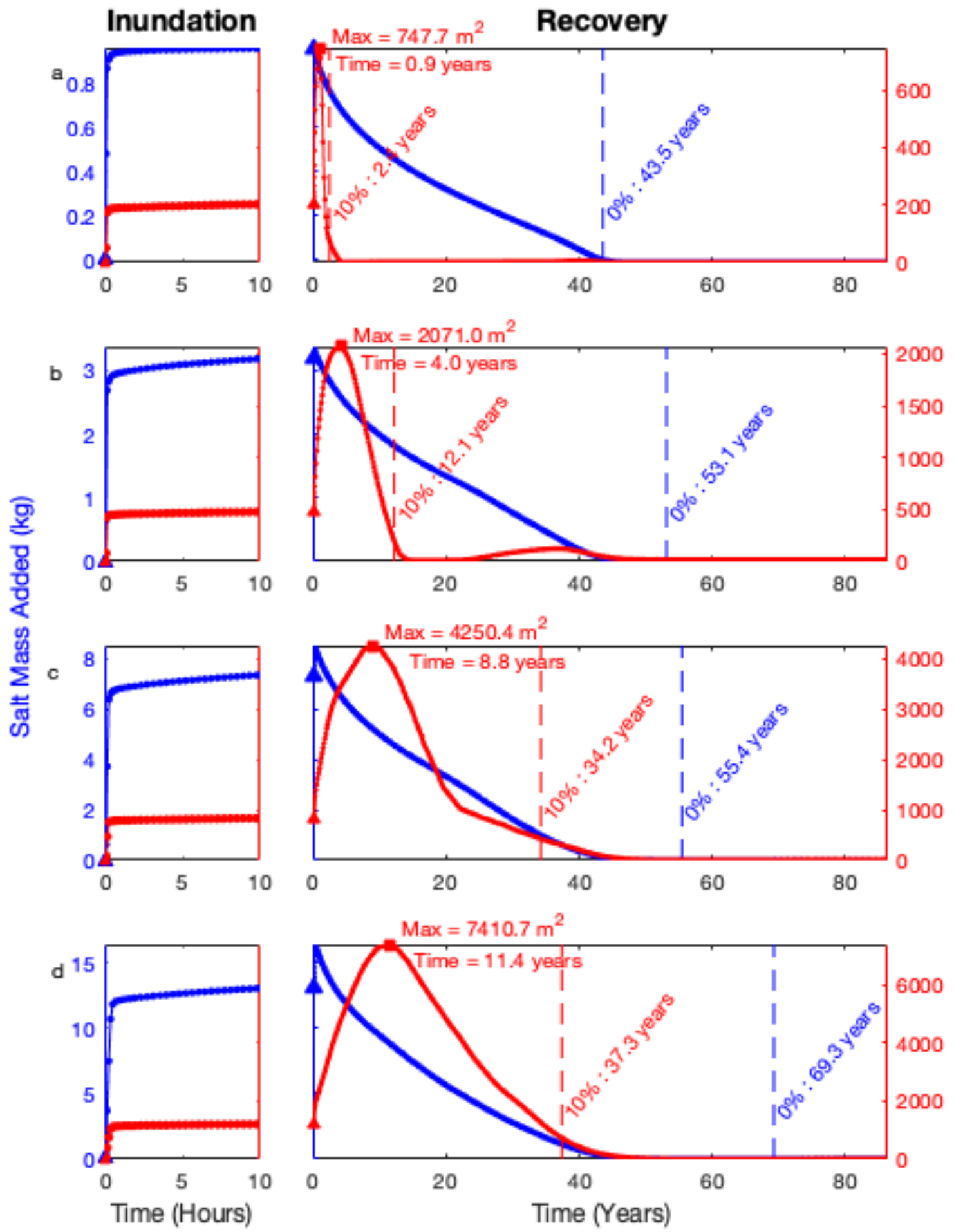

Figure 6: A comparison of model domains with the same recharge rate $(15 \mathrm{~cm} / y$ ear) with different unsaturated zone thicknesses: (a) base model, (b) base model plus an additional 1 m of unsaturated zone thickness, (c) base model plus an additional $2 \mathrm{~m}$ of unsaturated zone thickness, and (d) base model plus an additional $3 \mathrm{~m}$ of unsaturated zone thickness. 'Max' values indicate maximum salinized area and 'Time' values are when maximum salinized area occurs. '10\%' indicates the time at which the maximum salinized area is reduced by 90\%. '0\%' is the time that the salt mass added returns to pre-inundation conditions. 
However, while increased unsaturated zone thickness resulted in longer times needed to return the system to pre-inundation conditions, the thickness had minimal impact on the time required to reduce the added salt mass by $90 \%$ (Appendix A, Figure 9). The added salt mass to the base model returned to $10 \%$ of the maximum value 36.6 years post-inundation. Meanwhile, models with an additional 1, 2, 3 meters of unsaturated zone thickness reduced their maximum values by $90 \%$ in $37.2,35.3$, and 34.9 years, respectively. Despite having little impact on the length of time required to reduce the added salt mass by $90 \%$, the difference in time needed to return the added salt mass to pre-inundation conditions is likely a product of thicker unsaturated zones allowing more salt mass to enter the fresh aquifer.

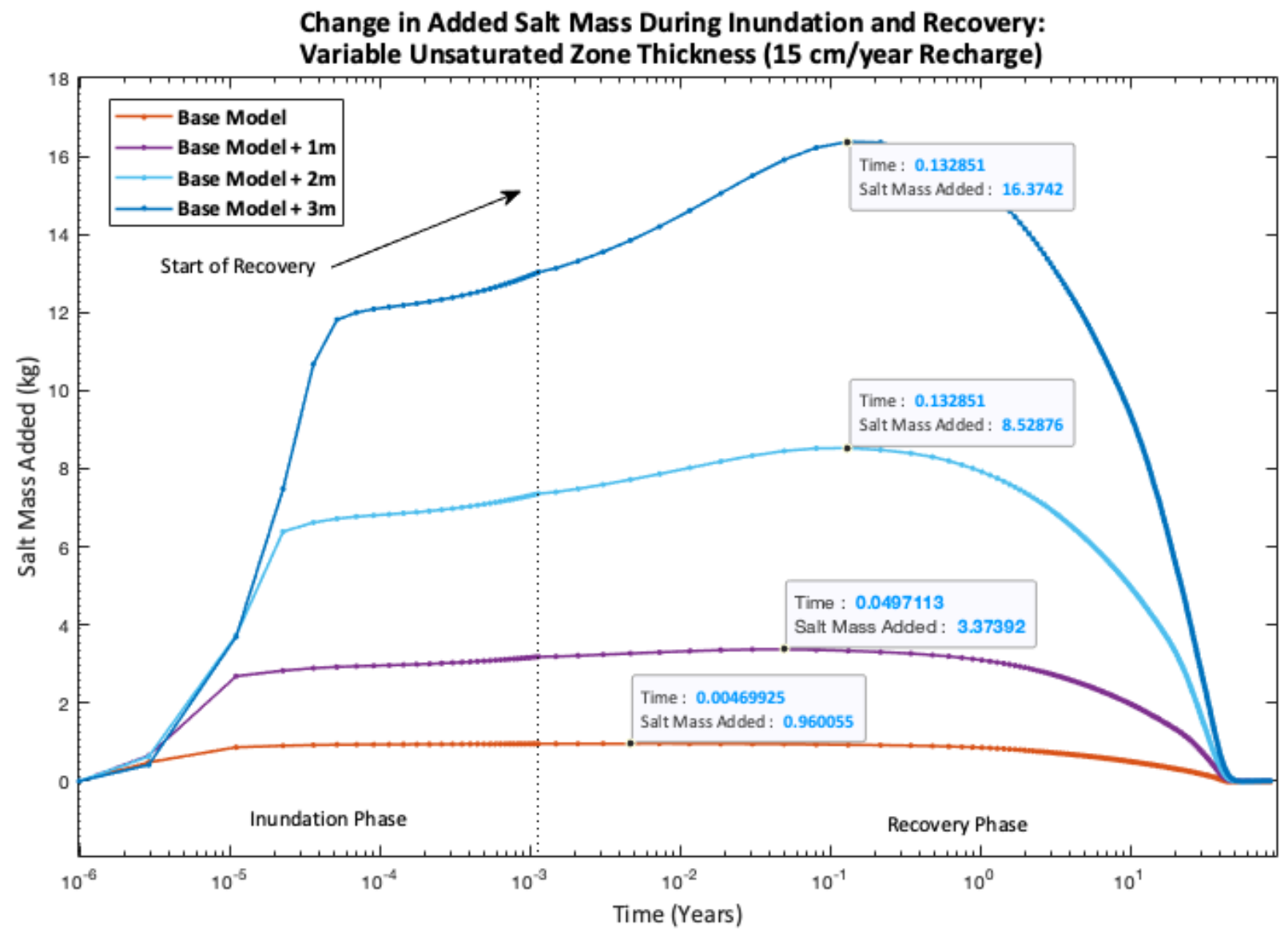

Figure 7: Change in the added salt mass for four models with different unsaturated zone thicknesses to compare maximum values and time required to return to pre-inundation conditions. Boxes indicate maximum added salt mass (in $\mathrm{kg}$ ) and the time (in years) at which they occurred.

Initial centroid positions are higher and further landward in models with thicker unsaturated zones. For the first 20 years post-inundation, models with thicker unsaturated zones feature 
centroid paths with vertical trajectories that travel deeper within the aquifer than the base model, likely due to increased mass and volume of the infiltrated seawater. From 20 to 40 years, the centroid paths of these models are directed seaward and slightly upward as the centroid approaches the interface. The centroid paths for all models follow one another after about 40 years (Figure 8), coincident with the time that the salt plume mass for each model had been reduced by $90 \%$ (Appendix A, Figure 9) - this is likely because added salt masses and salt concentrations in the fresh lens have decreased, the simulation is near steady state, and the centroid is heavily influenced by salt along the fresh-saline interface.

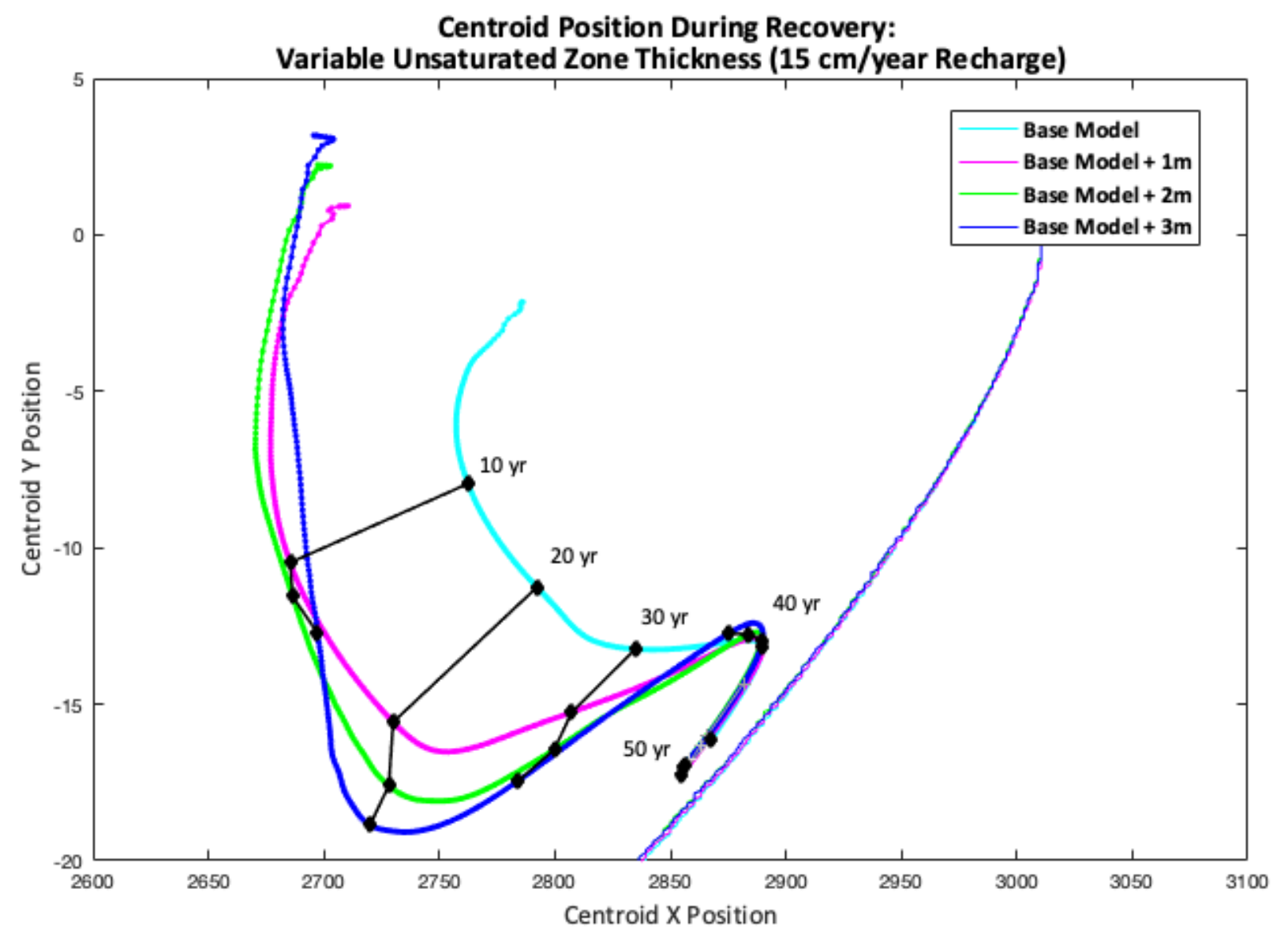

Figure 8: Mass centroid positions for four models with different unsaturated zone thicknesses to compare trajectories within the aquifer during recovery. Diamonds (connected by black lines) indicate the location of the mass centroid at 10-year intervals. The multi-color line is the location of the freshwater-saltwater interface; the interfaces for each model are plotted on-top of one other.

Additional simulations were run to compare the base model domain with domains that had thicker unsaturated zones, as described above, but with differing recharge rates $(5,10,20$, and 25 
$\mathrm{cm} / \mathrm{yr}$ ). The maximum salinized area greater than $0.6 \mathrm{ppt}$ and total salt mass, as well as the time required to decline below $10 \%$ of the maximum values, was also assessed. Figures for each can be found in Appendix A (Figures 1-4).

\subsubsection{Recharge}

The recharge applied to the model domain has an impact on both the maximum salinized area and the time required to flush the plume following an overtopping event. The maximum salinized area greater than $0.6 \mathrm{ppt}$ decreased as the rate of recharge increased - the lowest recharge model had the largest maximum salinized area. This agrees with previous work that showed inundation impacts are greater under drier conditions (i.e. less recharge; Chui and Terry, 2012). The model with the highest recharge ( $25 \mathrm{~cm} / \mathrm{year}$ ) had a maximum salinized area of only $482.1 \mathrm{~m}^{2}$ (Figure 9e), which was $65 \%$ of the maximum salinized area of the base model (Figure 9c) and was reached at 0.2 years post-inundation, less than one quarter the time for the base model. The maximum salinized area for the model with the highest recharge decreased rapidly and returned to $10 \%$ of the maximum area 0.6 years post-inundation, which was nearly two years sooner than the base model.

The added salt mass was less in models with higher recharge, but, unlike with different unsaturated zone thicknesses, the flushing times required to reach pre-inundation conditions decreased with increasing recharge rate. For the base model, and models with lower recharge values, the maximum salt mass added occurred within the first week of the recovery period (Figure 10). However, models with higher recharge than the base model, the maximum added salt mass occurred during the Inundation period. This is likely due to the increased recharge causing rapid dilution of the saline plume. Models with greater recharge values had relatively less added salt mass. While the added salt mass for the highest recharge model reached a maximum of $0.65 \mathrm{~kg}$, the lowest recharge model reached a maximum value of $1.42 \mathrm{~kg}$, about 2.2 times greater. Greater recharge values allow for less salt mass added to the aquifer and permit quicker flushing times from the aquifer. Additionally, all models except the lowest recharge model return to pre-inundation conditions by the end of the Recovery phase. 


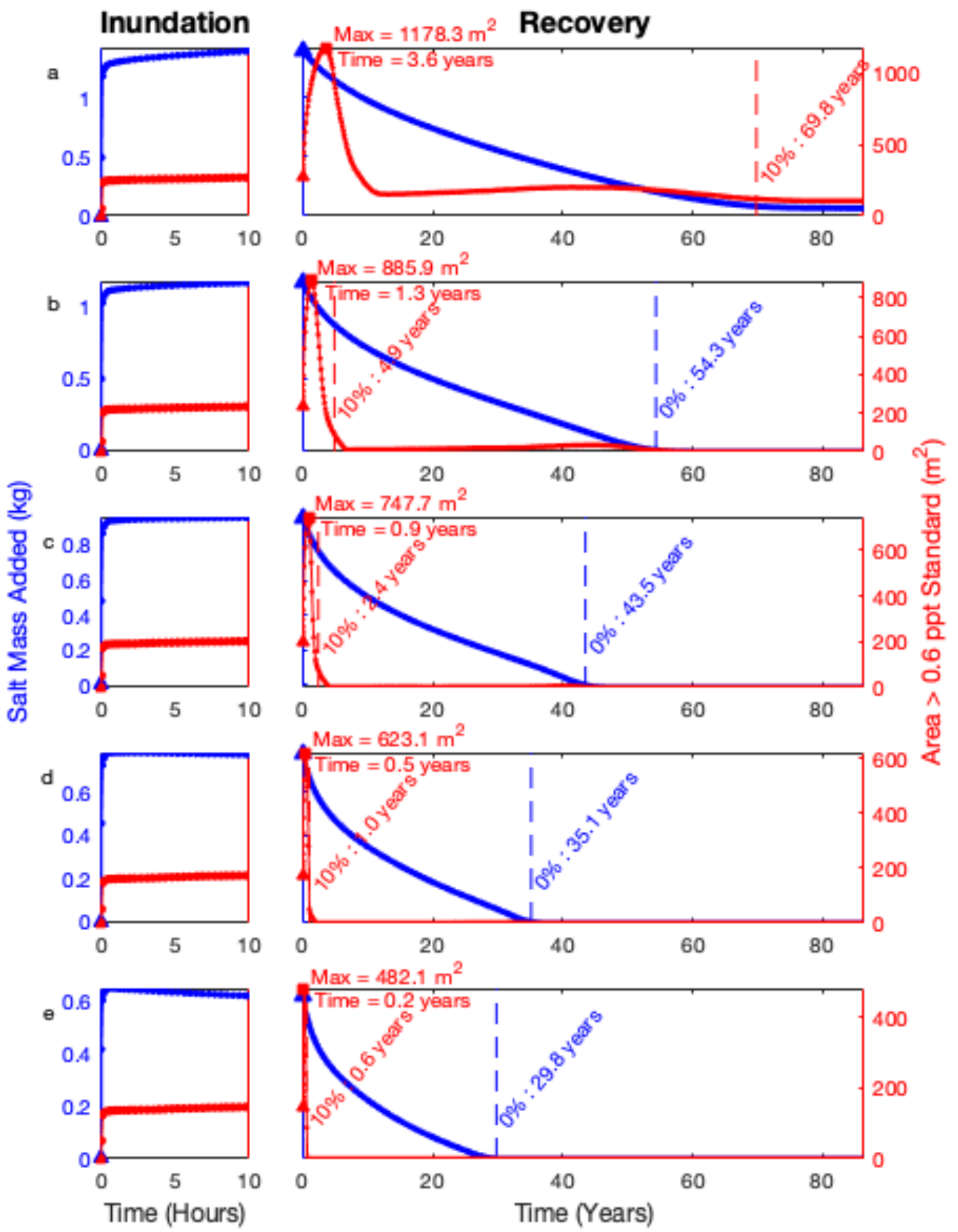

Figure 9: A comparison of base model domains with different recharge rate: (a) $5 \mathrm{~cm} / y e a r$, (b) $10 \mathrm{~cm} / y e a r$ (c) 15 $\mathrm{cm} /$ year, (d) $20 \mathrm{~cm} / y e a r$, and (e) $25 \mathrm{~cm} / y e a r$. Values provided are the maximum salinized area greater than 0.6 ppt for each scenario. 'Max' values indicate maximum salinized area and 'Time' values are when maximum salinized area occurs. ' $10 \%$ ' indicates the time at which the maximum salinized area is reduced by 90\%. '0\%' is the time that the salt mass added returns to pre-inundation conditions (if applicable). 


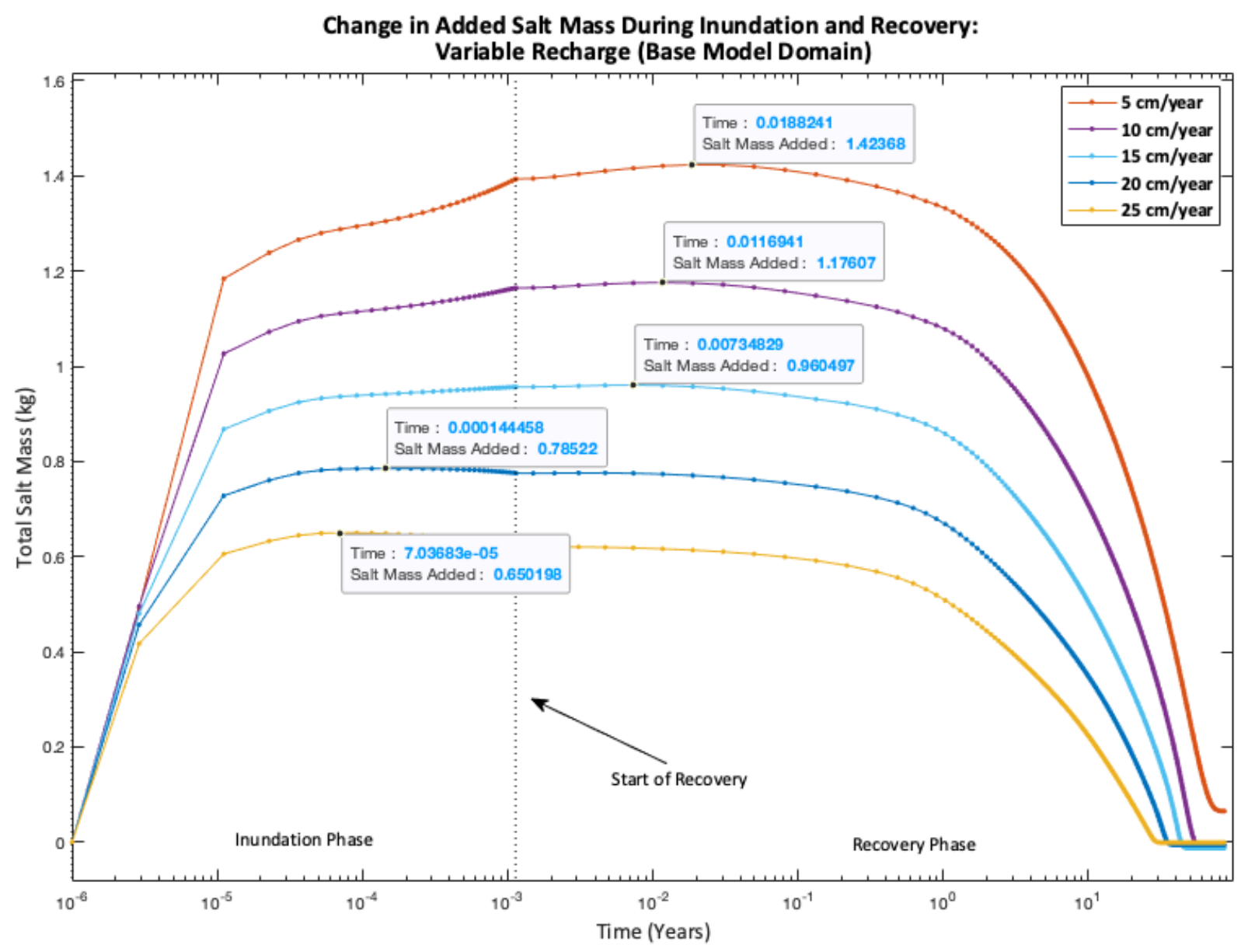

Figure 10: Change in the added salt mass for five models with different recharge to compare maximum values and time required to return to pre-inundation conditions. Boxes indicate maximum added salt mass (in $\mathrm{kg}$ ) and the time (in years) at which they occurred.

Thicker freshwater lenses associated with high-recharge scenarios result in centroids that begin further seaward and travel along deeper paths than in low-recharge scenarios (Figure 11). As recharge rates increase, centroids for the models with higher recharge travel to greater depths than models with lower recharge within the same time frames. The freshwater lens for the lowest recharge model $(5 \mathrm{~cm} / \mathrm{year})$ is much thinner and has a more horizontal orientation than those of the other models. While the lowest recharge model has less distance to travel to reach the freshwater-saltwater interface, the low recharge rate does not allow the centroid to move quickly and, therefore, takes a longer amount of time to travel a shorter distance than the other models simulated. Higher recharge rates also correspond with centroid paths beginning farther seaward, which may help to explain the quicker return to pre-inundation conditions for higher recharge models (Figure 10). 


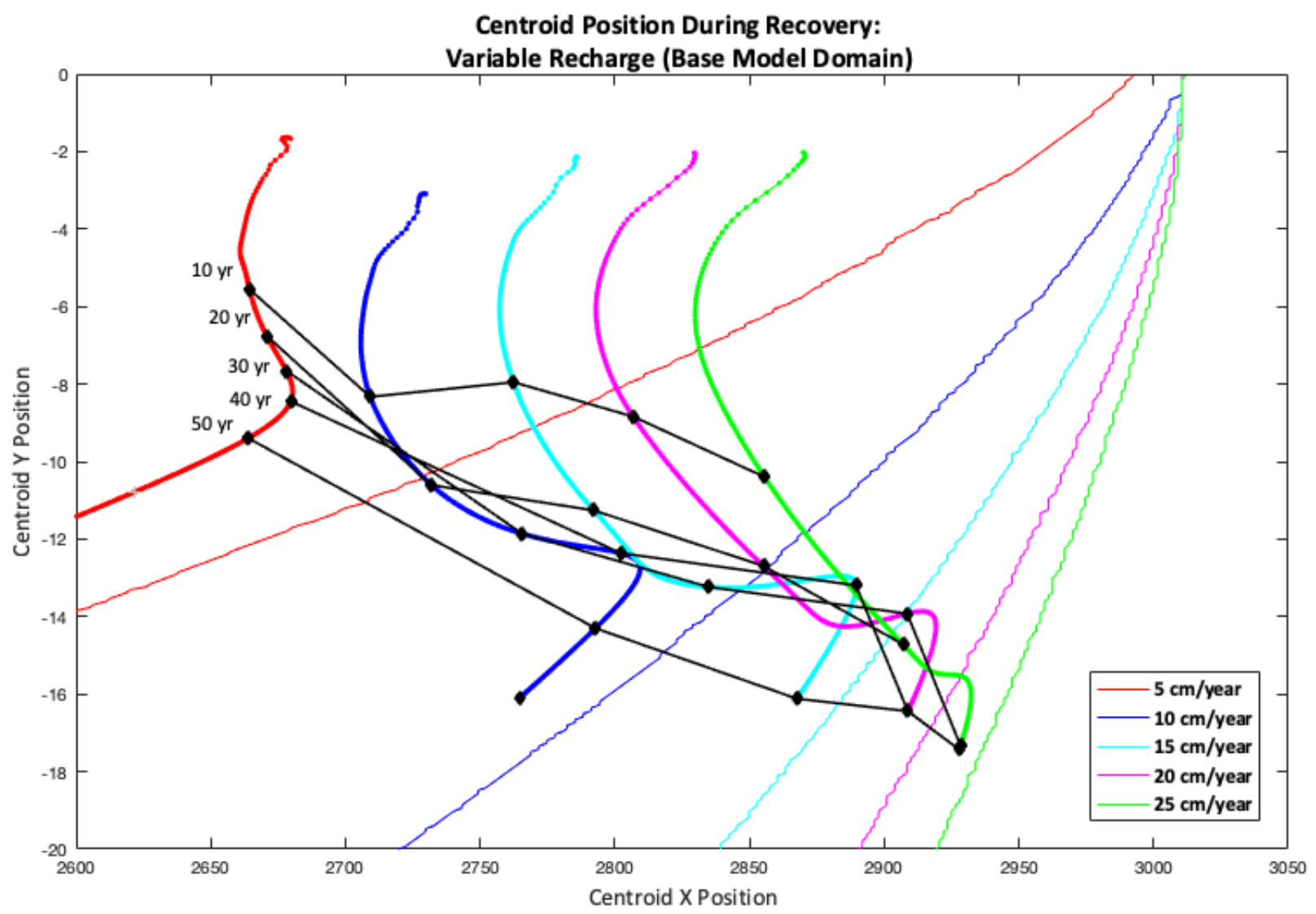

Figure 11: Mass centroid positions for five models with different recharge rates to compare trajectories within the aquifer during recovery. Diamonds (connected by black lines) indicate the location of the mass centroid at 10year intervals. The location of the freshwater-saltwater interface for each model is represented by its corresponding centroid path color.

Additional simulations were run to evaluate the impact recharge has on model domains with thicker unsaturated zones (additional 1, 2, and 3 m unsaturated zone thickness), as described above. The recharge rates are the same as those described above $(5,10,15,20$, and $25 \mathrm{~cm} /$ year). The maximum salinized area greater than $0.6 \mathrm{ppt}$ and total salt mass, as well as the time required to achieve $10 \%$ of maximum values, was also assessed. Figures for each can be found in Appendix A (Figures 5-7).

\subsubsection{Inundation Time}

The amount of time that the coastal aquifer was inundated had little impact on either the maximum salinized area or the time required to flush the saline plume. The maximum salinized area varied slightly as the inundation time increased, starting with $737.7 \mathrm{~m}^{2}$ for a 30 -minute 
inundation, then rising to $748.3 \mathrm{~m}^{2}$ for the 5-hour inundation simulation. After five hours, the maximum salinized area slowly decreased with increasing inundation time, all the way to 672.2 $\mathrm{m}^{2}$ for a 100 -hour inundation. There was only approximately a $10 \%$ difference between the highest and lowest maximum salinized areas. Models with much longer inundation times, however, did exhibit longer times to reduce the salinized area $10 \%$ of its maximum. Models with inundation times of 5 and 10 times longer than the base model (50 and 100 hours) had decreased maximum salinized areas, but an increase in flushing times to reduce the salinized area to $10 \%$ of the maximum. The decrease in maximum salinized areas for models with longer inundation times likely resulted from dispersion of the inundation seawater while inundation was still occurring. The model with a 50-hour inundation (Figure 12f) reached a maximum salinized area of $715.1 \mathrm{~m}^{2}$ at 0.8 years and returned to $10 \%$ of the maximum salinized area at 3.6 years postinundation, more than a half year longer than the 20-hour inundation (Figure 12e). The model with a 100-hour inundation (Figure 12g) had an even smaller salinized area and increased flushing times - maximum salinized area of $672.2 \mathrm{~m}^{2}$ was also reached at 0.8 years postinundation with a slightly longer return to $10 \%$ of the maximum salinized area at 3.8 years postinundation. Both the 50-hour and 100-hour inundation scenarios reduced by $90 \%$ over a year longer than the base model (Figure 12d). The lower salinized areas for the 50- and 100-hour Inundation periods may indicate dispersion of the inundated seawater concurrent with inundation.

Inundation time had little impact on the flushing time required to flush the saline plume. The maximum added salt mass for all models with inundation times less than 50 hours occurred at or near the start of recovery (Figure 13). The 100-year Inundation period, however, had a maximum added salt mass occur 31.9 hours into inundation. The maximum added salt masses for the models exhibited very little variation, ranging from $0.933 \mathrm{~kg}$ (30-minute simulation) to $0.964 \mathrm{~kg}$ (20--hour simulation). All models, regardless of inundation time, returned to pre-inundation conditions between 42.0- and 44.1-years post-inundation (Figure 12). In fact, each model ended with less mass at the end of the recovery period than was present pre-inundation. 

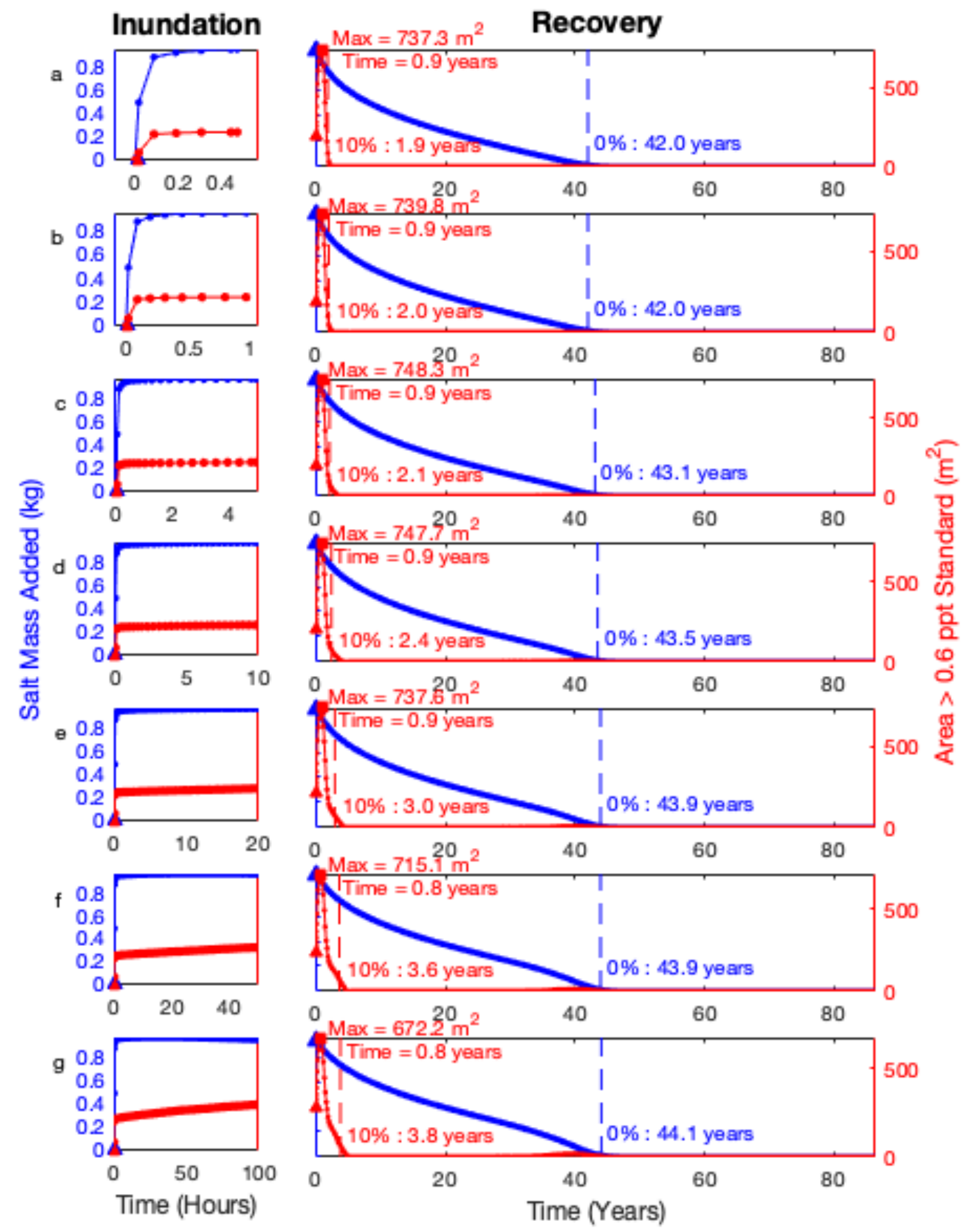

Figure 12: A comparison of different inundation times to the base model, with inundation times of: (a) 30 minutes, (b) 1 hour, (c) 5 hours, (d) 10 hours (base model), (e) 20 hours, (f) 50 hours, and (g) 100 hours. 


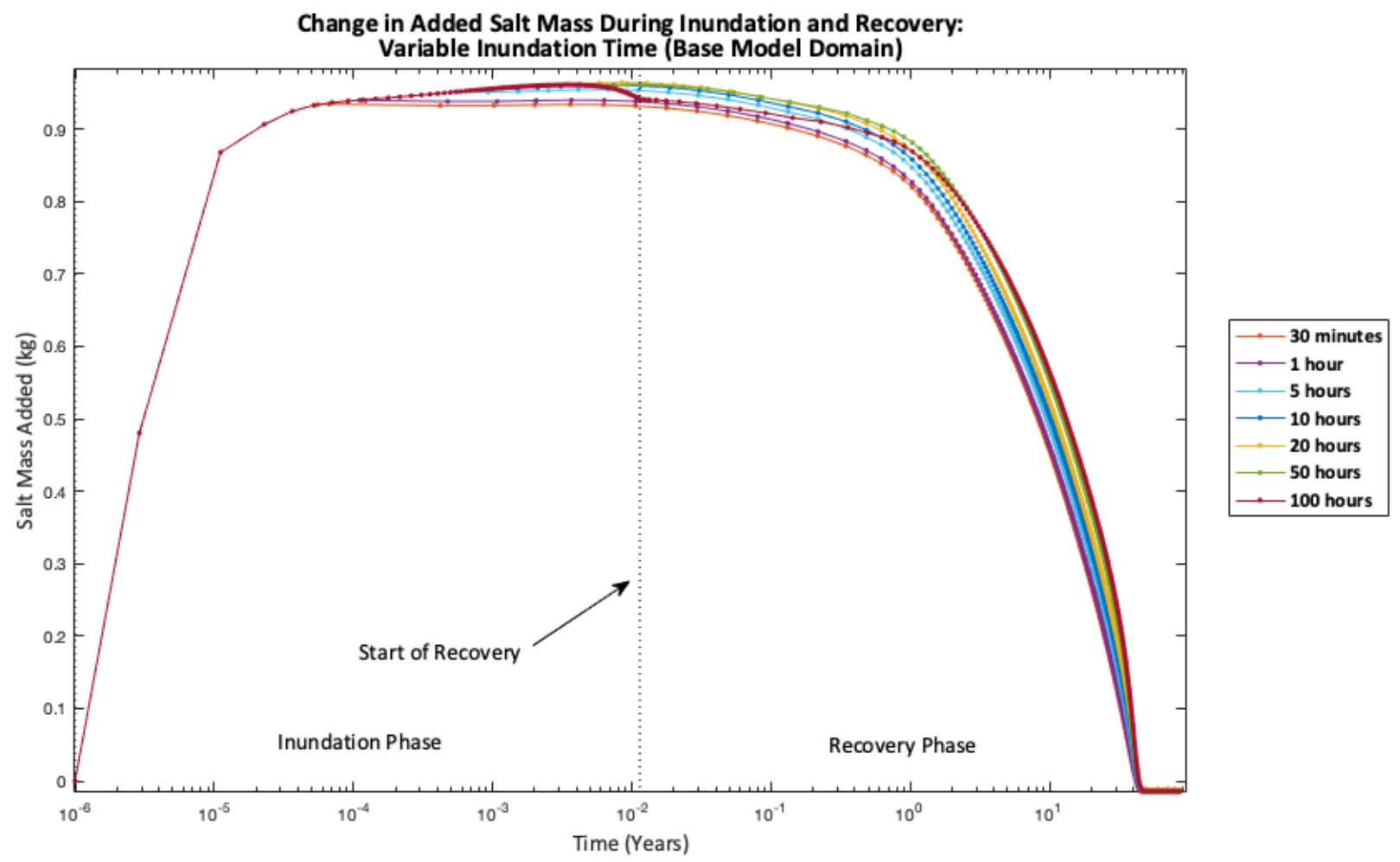

Figure 13: Change in the added salt mass for seven models with different inundation times to compare maximum values and time required to return to pre-inundation conditions.

Centroid paths for each model in the Inundation model set (Figure 14) all begin at similar elevations within the aquifer but take different paths. Centroids in models with greater inundation times begin farther landward because of lateral inland "spillover" beyond the landward inundation extent, creating a large finger at the landward extent, (i.e. figure $3 \mathrm{c}$ ), and reach greater depths than models with lower inundation times. For the first 10 years postinundation, all models feature centroid paths with vertical trajectories that travel deeper within the aquifer. However, from 10 to 30 years, the centroid paths of these models are directed seaward. From 30 to 40 years, they move slightly upward as the centroid approaches the interface. The centroid paths for all models follow one another after about 40 years, coincident with the time that most of the salt plume mass has left the fresh aquifer (Figure 12) - they converge along the interface. Note that recharge also controls the location of the interface within the coastal aquifer, as the interface was in the same position for each of the models. 


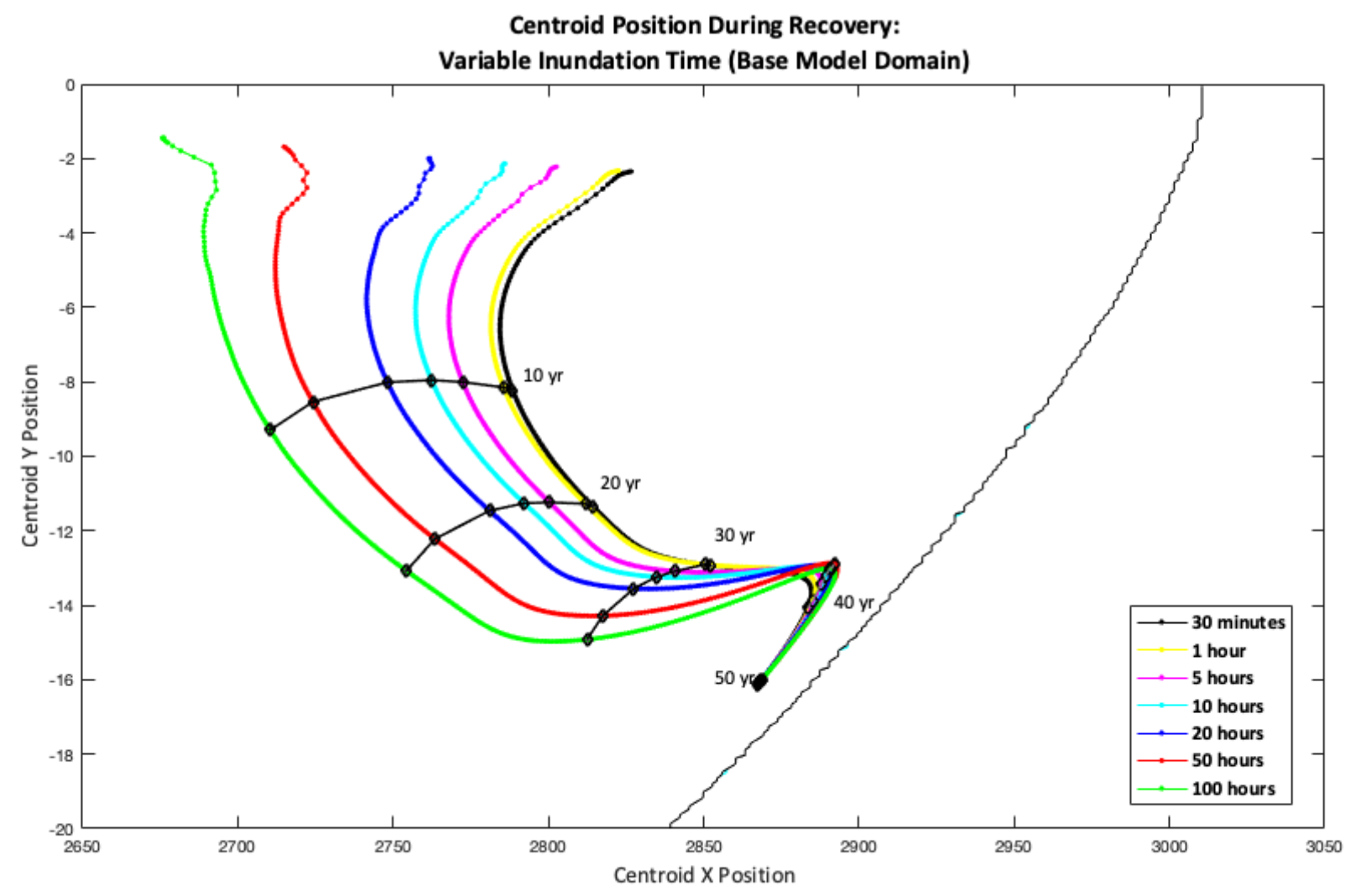

Figure 14: Centroid position of base model domain with different inundation times during the recovery period. Diamonds (connected by black lines) indicate the location of the mass centroid at 10-year intervals. The black line is the location of the freshwater-saltwater interface; the interface for each model is the same.

An additional simulation was run that compared the effect of varying the inundation time on a model domain with an additional two meters of unsaturated zone thickness. The recharge rate for each model was $15 \mathrm{~cm} /$ year. The maximum salinized area greater than $0.6 \mathrm{ppt}$ and total salt mass, as well as the time required to achieve $10 \%$ of maximum values, was also assessed. The results of that analysis are discussed in Section 4.3.

\subsubsection{Permeability}

The permeability of the model domain (Figure 15) has an impact on both the maximum salinized area greater than $0.6 \mathrm{ppt}$ and the flushing time needed to reduce the area to $10 \%$ of its maximum in coastal aquifers following an overtopping event. The maximum salinized area and the time needed to reach the maximum decreased when the permeability was slightly decreased $\left(5.5 \times 10^{-}\right.$ ${ }^{12}$ ) from the base model. The maximum salinized area was $43.9 \%$ of the base model and occurred 0.7 years earlier. Additionally, the model with a permeability of $5.5 \times 10^{-12}$ reduced to $10 \%$ of the 
maximum salinized area much sooner than the base model - more than a year and a half earlier. The model with a permeability of one order of magnitude smaller $\left(1.0 \times 10^{-12} \mathrm{~m}^{2}\right)$, while exhibiting a much lower maximum salinized area than the base model, took much longer for that salinized area to decrease by $90 \%$. The model with a permeability of $1.0 \times 10^{-12} \mathrm{~m}^{2}$ (Figure $15 \mathrm{c}$ ) exhibited a maximum salinized area of $14.3 \mathrm{~m}^{2}$, over 1,000 times less than the base model, where it began at the start of the Recovery period. It returned to $10 \%$ of the maximum salinized area 3.4 years after inundation, a full year longer than the base model. While the maximum salinized area was much lower than the other two models, it took longer to reduce by $90 \%$.

The added salt mass also decreased as the permeability of the model decreased. The maximum added salt mass for the base model happened later than the other models, occurring within the first 3 days, while it took only hours into the Inundation period for models with lower permeability (Figure 15, 16). The maximum added salt mass for the base model was more than twice as high as the model with a permeability of $5.5 \times 10^{-12} \mathrm{~m}^{2}$ and more than 32 times higher than the model with a permeability of $1.0 \times 10^{-12} \mathrm{~m}^{2}$. However, the flushing times required to get to pre-inundation conditions varied among all three models within the set with different permeabilities. Although the base model did return to pre-inundation conditions at approximately 43.5 years, the other permeability models returned to pre-inundation conditions both before (1.0 $\left.\mathrm{x} 10^{-12} \mathrm{~m}^{2}\right)$ and after $\left(5.5 \times 10^{-12} \mathrm{~m}^{2}\right)$ the base model. The model with a permeability of $5.5 \times 10^{-12}$ $\mathrm{m}^{2}$ returned to pre-inundation conditions 21.2 years into the Recovery period, more than twice as quickly as the base model, while the model with a permeability of $1.0 \times 10^{-12} \mathrm{~m}^{2}$ returned to preinundation conditions after 54.9 years, more than 11 years later than the base model. 

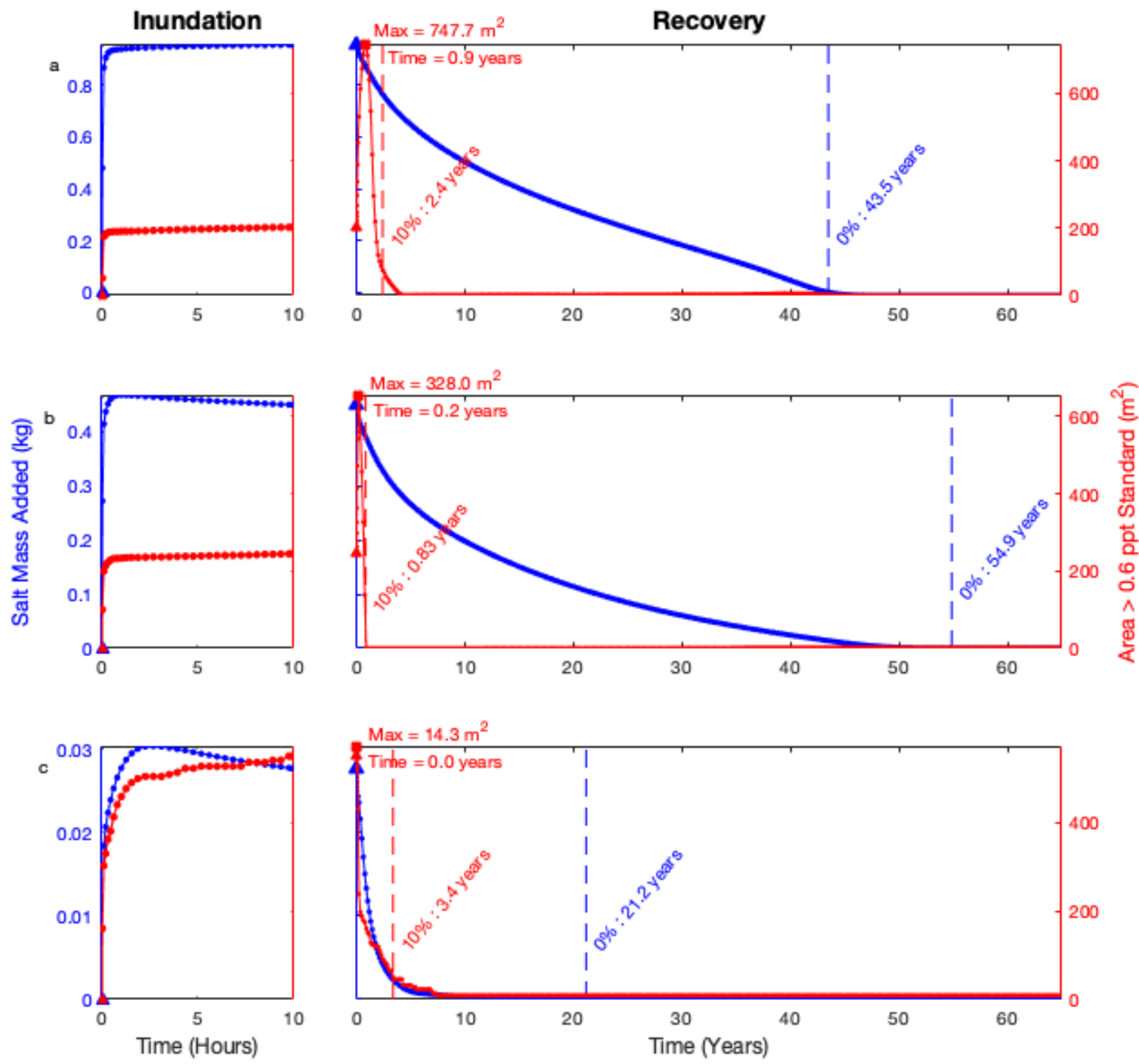

Figure 15: A comparison of the base model domain with different permeability vales: (a) $1.0 \times 10^{-11} \mathrm{~m}^{2}$, (b) $5.5 x$ $10^{-12} \mathrm{~m}^{2}$, and (c) $1.0 \times 10^{-12} \mathrm{~m}^{2}$. 


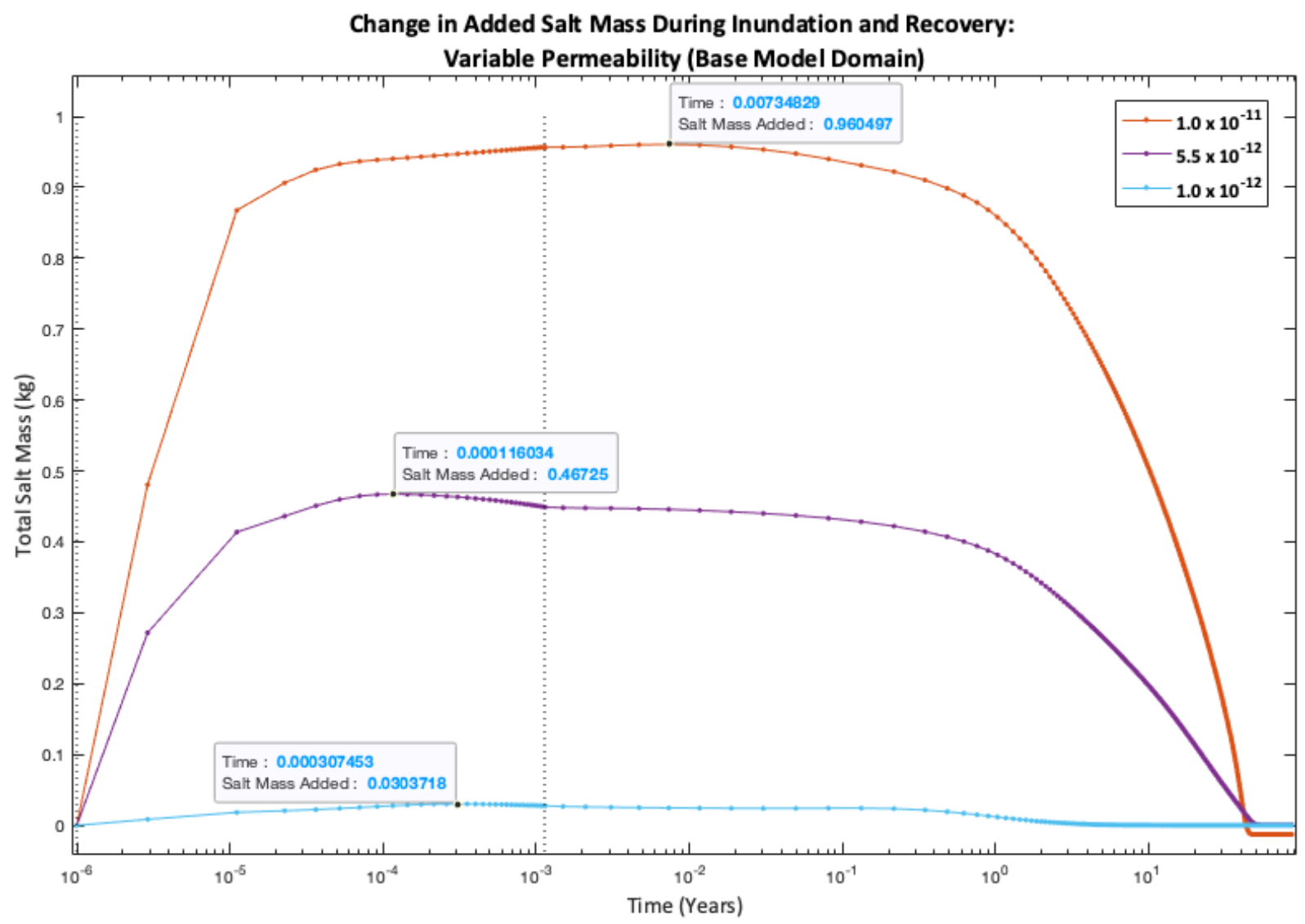

Figure 16: Change in the added salt mass for three models with different permeability to compare maximum values and time required to return to pre-inundation conditions. Arrows indicate maximum added salt mass and the time at which they occurred.

Thicker freshwater lenses associated with higher permeability scenarios result in centroids that begin further landward yet does not travel along a deeper path than in lower permeability scenarios (Figure 17). As the permeability decreases, centroids for the models with lower permeability travel to greater depths than models with higher permeability within the same time frames. The freshwater lens for the base model $\left(1 \times 10^{-11} \mathrm{~m}^{2}\right)$ is thinner and has a more diagonal orientation than those of the other models. Though the base model centroid has slightly more distance to travel to reach the freshwater-saltwater interface, it reaches pre-inundation conditions sooner than the model with a permeability of $5.5 \times 10^{-12} \mathrm{~m}^{2}$. The model with the lowest permeability $\left(1.0 \times 10^{-12} \mathrm{~m}^{2}\right)$ had a centroid path that was very different from the other models, where it stayed very close to the freshwater-saltwater interface, coincident with the low added salt mass value recorded during the simulation. 


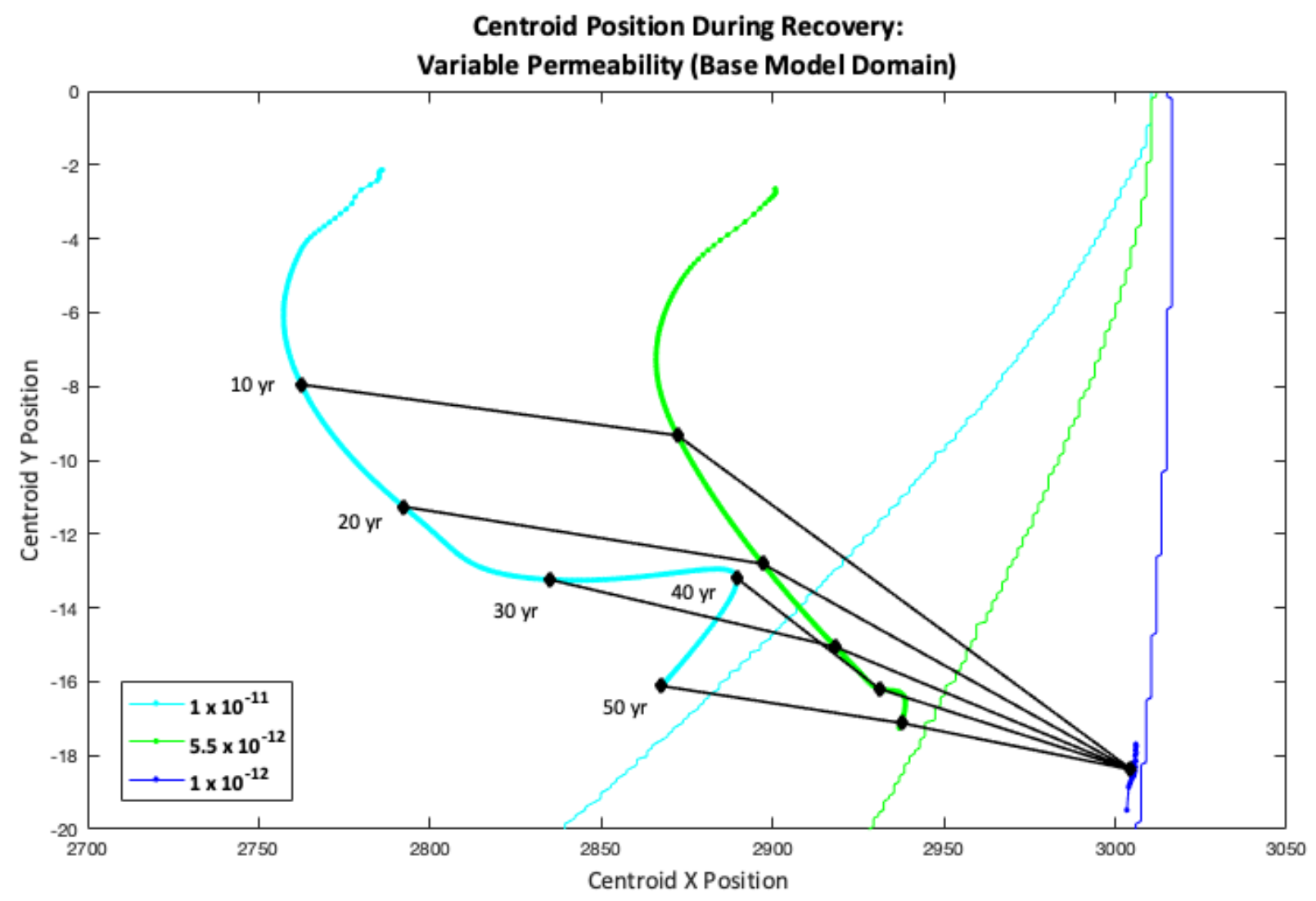

Figure 17: Centroid position of base model domain with different recharge values during recovery. Diamonds (connected by black lines) indicate the location of the mass centroid at 10-year intervals. The location of the freshwater-saltwater interface for each model is represented by its corresponding centroid path color.

\section{Discussion}

\subsection{Numerical Findings}

\subsubsection{Unsaturated Zone Thickness}

The unsaturated zone thickness is a primary control on the severity of saltwater contamination following an overtopping event. The unsaturated zone fills and stores seawater that infiltrates during overtopping events that degrades aquifer water quality until it has been flushed through the aquifer. The contaminated volume and salt mass introduced depend on the unsaturated zone thickness - a thicker unsaturated zone allows more inundated seawater (and salt mass). In a model set comparing the effects of progressively thicker unsaturated zones, the maximum salinized area and salt mass within the aquifer following inundation increased as the unsaturated zone thickness increased. Compared to the base model: an additional meter (base $+1 \mathrm{~m}$ ) of unsaturated zone thickness resulted in nearly 2.8 times greater maximum salinized area (Figure 

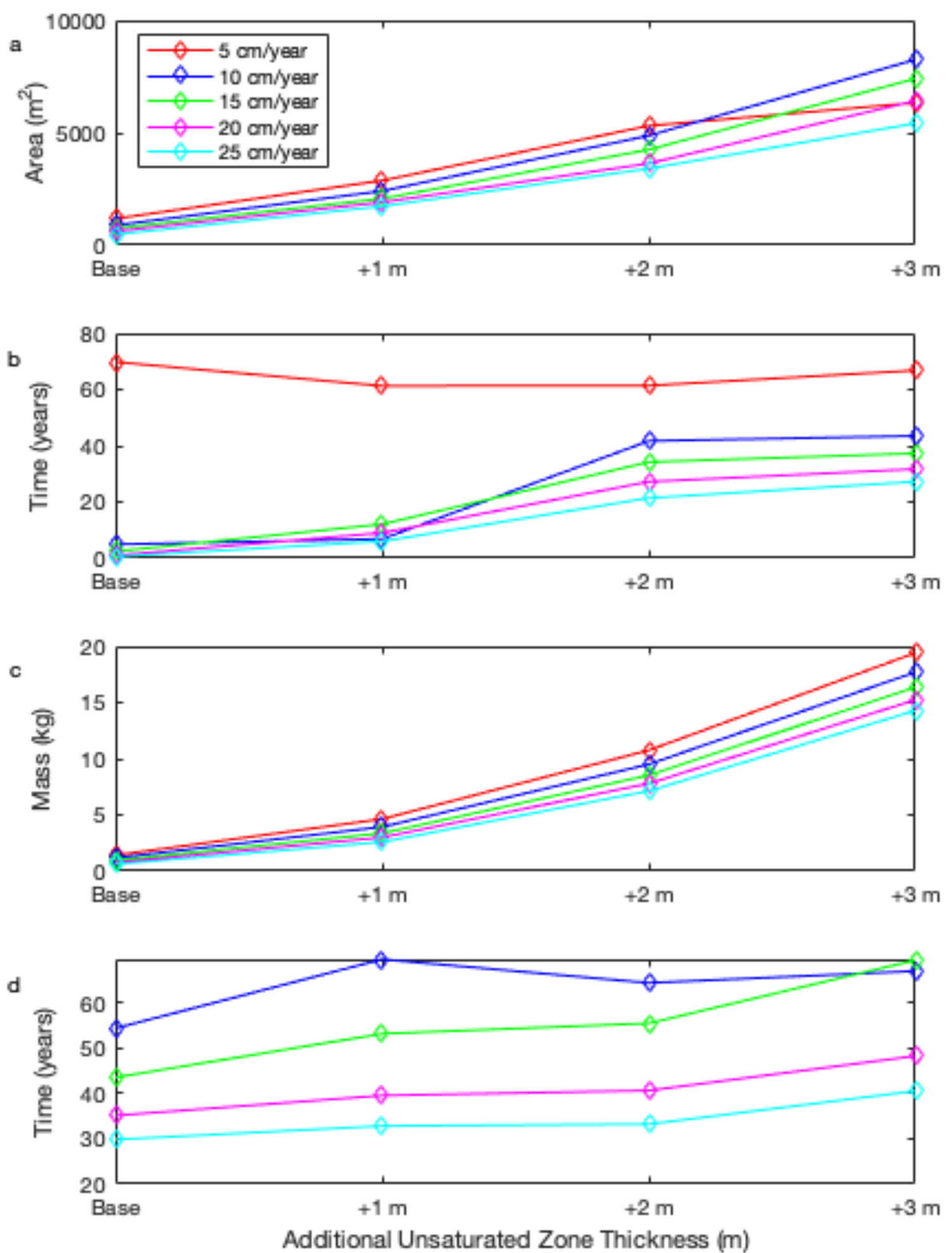

Figure 18: A comparison of indicators for different unsaturated zone thicknesses: (a) the maximum salinized area, (b) time needed to return to $10 \%$ of the maximum salinized area, (c) the maximum salt mass added, and (d) time needed for salt mass added return to pre-inundation conditions. $15 \mathrm{~cm} / y$ ear (green line) was the base model. 
18a) and 3.5 times the salt mass (Figure 18c), two additional meters of unsaturated meters (base $+2 \mathrm{~m}$ ) resulted in approximately 5.7 times greater maximum salinized area and almost 9 times the salt mass; three additional meters of unsaturated meters (base $+3 \mathrm{~m}$ ) resulted in almost 10 times greater maximum salinized area and 17 times the salt mass. Model sets assessing the same unsaturated zone thicknesses with different recharge rates yielded similar conclusions for salinized area (Figure 18a) and salt mass (Figure 18c).

The maximum salinized area increases with increasing unsaturated zone thickness (Figure 18a). On average, an additional meter of unsaturated zone thickness resulted in nearly three times the maximum salinized area reached in the base model. Additionally, further increases in unsaturated zone thickness (two and three meters) beyond that of the base model exhibited greater growth. An additional two meters of unsaturated zone thickness resulted in, on average, 5.7 times the maximum salinized area reached in the base model, and an additional three meters of unsaturated zone thickness resulted in an over nine times increase in the maximum salinized area reached in the base model. These values are likely weighed down by the $5 \mathrm{~cm} /$ year recharge simulations, which saw the lowest increases across all additional unsaturated zone thicknesses assessed -2.4 , 4.5, and 5.4 times increase in maximum salinized area, respectively.

The maximum salinized area for the model with an additional three meters of unsaturated zone thickness and recharge of $5 \mathrm{~cm} /$ year was anomalously lower than expected by comparison with the trends of other model sets (Figure 18a, red line). Because the maximum added salt mass for this simulation followed the trend of different model sets (Figure 18c, red line), a likely explanation for the lower-than-expected maximum salinized area is that the slow velocities associated with the low recharge resulted in less dispersion than for the higher recharge scenarios. The plume, accordingly, did not disperse into a larger area at a concentration greater than $0.6 \mathrm{ppt}$ as quickly as other model set simulations.

In general, the time required for salinized area to reduce to $10 \%$ of the maximum salinized area was longer for thicker unsaturated zones (Figure 18b). The difference in time was calculated for different unsaturated zone thickness domains by comparing indicators across all recharge rates for that domain. Excluding the $5 \mathrm{~cm} /$ year simulations, the time needed to reduce the salt mass to 
$10 \%$ of its maximum averaged 2.2 years for base models, 8.5 years for base $+1 \mathrm{~m}$ models, 31.1 years for base $+2 \mathrm{~m}$ models, and 34.9 years for base $+3 \mathrm{~m}$ models. The greatest change in time was between the base $+1 \mathrm{~m}$ and base $+2 \mathrm{~m}$ models, whereas much less change was calculated between the base and base $+1 \mathrm{~m}$ models, and even less between the base $+2 \mathrm{~m}$ and base $+3 \mathrm{~m}$ models. However, models with a recharge of $5 \mathrm{~cm} /$ year each had similarly high reduction times (Figure 18b, red line) - between 61.3 (base $+1 \mathrm{~m}$ ) and 69.8 years (base model).

The maximum added salt mass increases with increasing unsaturated zone thickness (Figure 18c). On average, an additional meter of unsaturated zone thickness resulted in an increase of 3.6 times the added salt mass reached in the base model. Additionally, further increases in unsaturated zone thickness (two and three meters) beyond that of the base model exhibited continued growth. An additional two meters of unsaturated zone thickness resulted in, on average, over nine times the maximum salt mass added in the base model, and an additional three meters of unsaturated zone thickness resulted in an average of 17.7 times the maximum added salt mass reached in the base model.

In general, the time required for the salt mass to return to pre-inundation conditions increased with increasing unsaturated zone thickness (Figure 18d). Models with recharge rates between $15-25 \mathrm{~cm} /$ year exhibited increased flushing time with increasing unsaturated zone thickness, while the models with a $10 \mathrm{~cm} /$ year recharge rate exhibited more volatility (and an anomalously higher than expected flushing time for the base $+1 \mathrm{~m}$ model). None of the models with a recharge of $5 \mathrm{~cm} /$ year returned to pre-inundation conditions, so they are not plotted in Figure 18d. Mass centroid paths during the Recovery period can explain the longer times. Each model with a thicker unsaturated zone featured a mass centroid path that not only began at a higher elevation and further landward within the aquifer but took much more vertical trajectories during recovery before making a more horizontal turn toward the interface. The greater vertical movement of the plume indicates that it has stayed within the aquifer for a more extended amount of time.

While the time required to return the salt mass to pre-inundation conditions increased with increasing unsaturated zone thickness, the time needed to reduce the added salt mass to $10 \%$ of the maximum added salt mass was insensitive to unsaturated zone thickness. For the $15 \mathrm{~cm} /$ year base model set, the added salt mass to the base model returned to $10 \%$ of the maximum value 
36.6 years post-inundation. Models with thicker unsaturated zones had maximum added salt mass values reduced to $10 \%$ in similar time frames. Mass centroid paths varied between models, but generally mirrored other from 40 years into post inundation onwards, coinciding with the approximate time needed for the added salt mass in each model to reduce the salt mass to $10 \%$ of the maximum. Although added salt masses decline to $10 \%$ of the maximum in similar temporal scales, more salt infiltrates systems with thicker unsaturated zones during the Inundation period, likely causing the return to pre-inundation conditions to be longer.

\subsubsection{Recharge}

Recharge plays an important role in the size of the salinized area and added salt mass within the aquifer following an overtopping event. In simulations comparing the effect of progressively higher recharge rates, the maximum salinized area and added salt mass within the aquifer following inundation decreased as the recharge increased. A low recharge scenario $(5 \mathrm{~cm} /$ year $)$ simulates dry conditions and had a maximum salinized area 1.6 times greater than the maximum salinized area of the base model $(15 \mathrm{~cm} /$ year $)$, and nearly 2.8 times that of the simulation with highest recharge $(25 \mathrm{~cm} /$ year). Additionally, the model with a recharge of $5 \mathrm{~cm} /$ year exhibited the highest added salt mass, $1.42 \mathrm{~kg}$, which decreased as the recharge was increased to other models within the model set. The base model $(15 \mathrm{~cm} /$ year) had $67 \%$ of the added salt mass of the lowest recharge $(5 \mathrm{~cm} /$ year) simulation, while the highest recharge model $(25 \mathrm{~cm} /$ year) only had $46 \%$ of the lowest recharge model. Model sets assessing the same recharge rate with different unsaturated zone thicknesses yielded similar conclusions for salinized area and added salt mass (Figure 19a, c). 

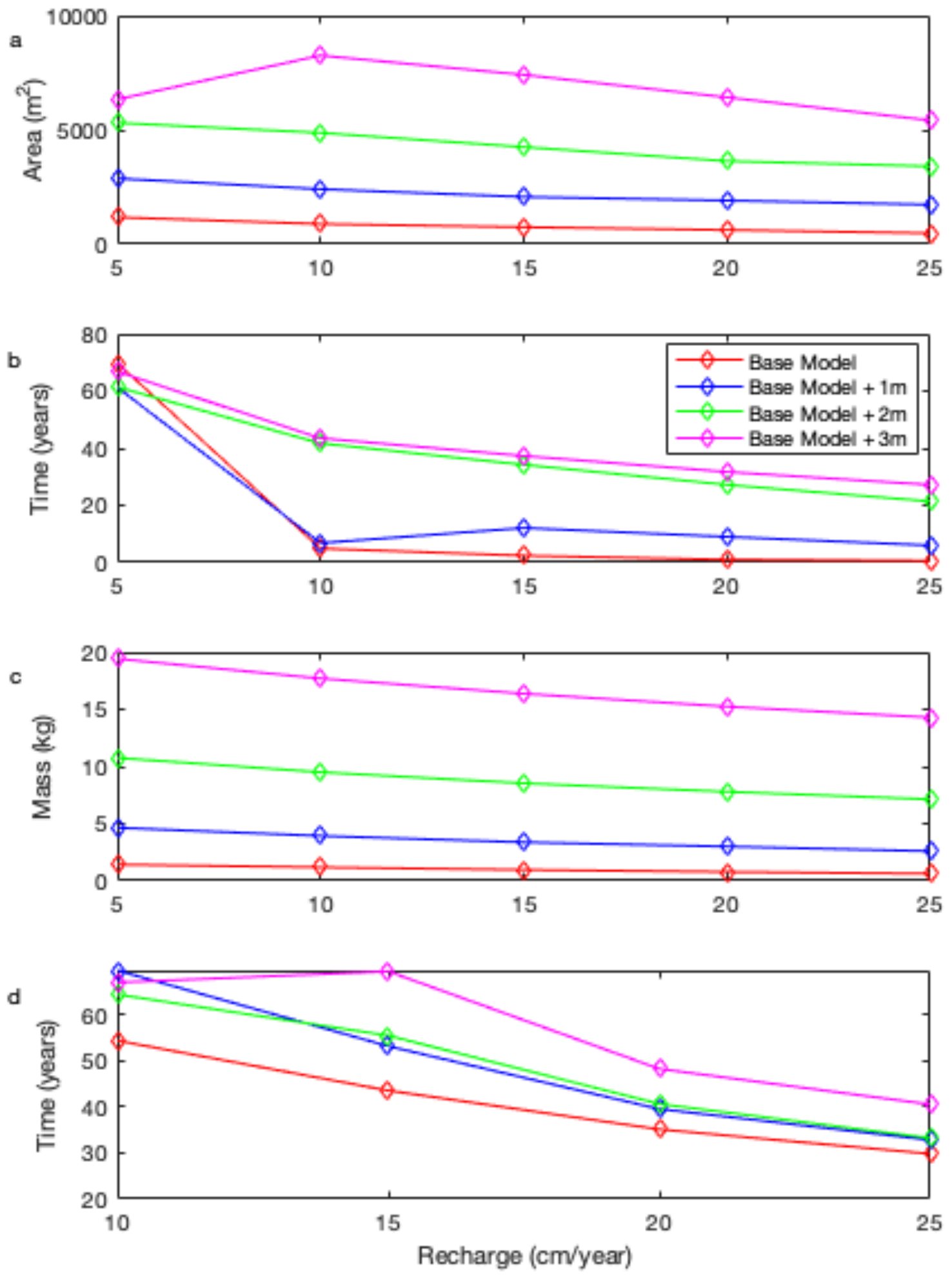

Figure 19: A comparison of indicators for different recharge rates: (a) the maximum salinized area, (b) time needed to reach $10 \%$ of the maximum salinized area, (c) the maximum salt mass added, and (d) time needed for salt mass added return to pre-inundation conditions. 
The maximum salinized area decreased with increasing recharge (Figure 19a). Comparatively and within each individual model set, the results indicate the role that recharge plays in dispersing and diluting inundated seawater following an overtopping event. On average, models with a recharge of $15 \mathrm{~cm} /$ year had a maximum salinized area $84 \%$ that of the lowest recharge (5 $\mathrm{cm} /$ year) and models with a recharge of $25 \mathrm{~cm} /$ year had a maximum salinized area $63 \%$ that of the lowest recharge. These values are likely high due to the lower than expected $5 \mathrm{~cm} /$ year recharge simulation to the base $+3 \mathrm{~m}$ model, which didn't follow the trend of other model sets.

Recharge rate is an important control on the time required to flush salt mass and reduce salinized areas to pre inundation conditions. The time required for salinized area to reduce to $10 \%$ of the maximum decreased with increasing recharge (Figure 19b). The base model set exhibited the greatest change in reduction times from the lowest to highest recharge models. The highest recharge model ( $25 \mathrm{~cm} /$ year) returned to $10 \%$ of its maximum salinized area in just over a half a year, more than 69 years quicker than the model with the lowest recharge $(5 \mathrm{~cm} / \mathrm{year})$. Other model sets had similar results. The highest recharge model within the base $+1 \mathrm{~m}$ model set returned to $10 \%$ of its maximum salinized area more than 55 years quicker than the lowest recharge model. Similarly, the highest recharge model for both the base $+2 \mathrm{~m}$ and base $+3 \mathrm{~m}$ models were reached around 40 years sooner than their lowest recharge counterparts. Quicker reduction of salinized area in models with higher recharge rates is likely due to less salt mass entering the aquifer in high recharge simulations and faster groundwater velocities associated with higher recharge rates caused more rapid dispersion of the saline plume.

The maximum added salt mass decreases with increasing recharge. Model sets assessing the different unsaturated zone thicknesses with the same recharge rates yielded similar conclusions (Figure 19c). On average, models with a recharge of $15 \mathrm{~cm} /$ year had a maximum added salt mass $76 \%$ that of the lowest recharge ( $5 \mathrm{~cm} /$ year) and models with a recharge of $25 \mathrm{~cm} /$ year had a maximum added salt mass $60 \%$ that of the lowest recharge.

Generally, the time required for the salt mass to return to pre-inundation conditions decreased with increasing recharge (Figure 19d). Models with low recharge rates exhibited the longest flushing times, while models with progressively higher recharge had quicker flushing times. In 
each model set, the quickest times needed to return to pre-inundation conditions were found in the $25 \mathrm{~cm} /$ year simulations. Thicker freshwater lenses associated with high-recharge scenarios result in centroids that begin further seaward and travel along deeper paths than in low-recharge scenarios. In combination with faster groundwater velocities associated with higher recharge, salt masses return to pre-inundation conditions more quickly for higher recharge models.

\subsubsection{Inundation Time}

The duration of inundation had minimal impact on the severity of saltwater contamination from an overtopping event to the base model. However, the duration of inundation applied to a thicker unsaturated zone does factor into the size of the maximum salinized area and added salt mass. Only several hours are required for seawater to infiltrate and thoroughly saturate a typical unsaturated zone (1-3 m thick, $\mathrm{k}=1 \times 10^{-11}$; Illangasekare et al., 2006). Once fully saturated, the rate of seawater infiltration slows, so it is expected that simulations with longer inundation times will not show a marked increase in the severity of contamination. This would confirm Chui and Terry's (2012) findings that additional inundation time does not significantly worsen the severity of contamination. For the base model, there was little variation in the maximum salinized area for inundation times ranging from 30 minutes to 100 hours (Figure 20a, red line)). The highest maximum salinized area occurred when the duration of inundation was 5 hours $\left(748.3 \mathrm{~m}^{2}\right)$, while the lowest occurred for the 100-hour Inundation period $\left(672.2 \mathrm{~m}^{2}\right)$. The range in maximum salinized areas for the base model was $76.1 \mathrm{~m}^{2}$. The maximum salinized areas remained relatively stable up to the 20-hour Inundation period, whereafter the maximum salinized areas slightly decreased. The decrease in maximum salinized areas for longer inundation times may be due to the plume experiencing dispersion and dilution while inundation is still occurring. The change, however, was relatively small, with the maximum salinized area only decreasing just under $10 \%$ from the highest maximum value reached at 5 hours, indicating that very little time is necessary to fully saturated the base model unsaturated zone. 

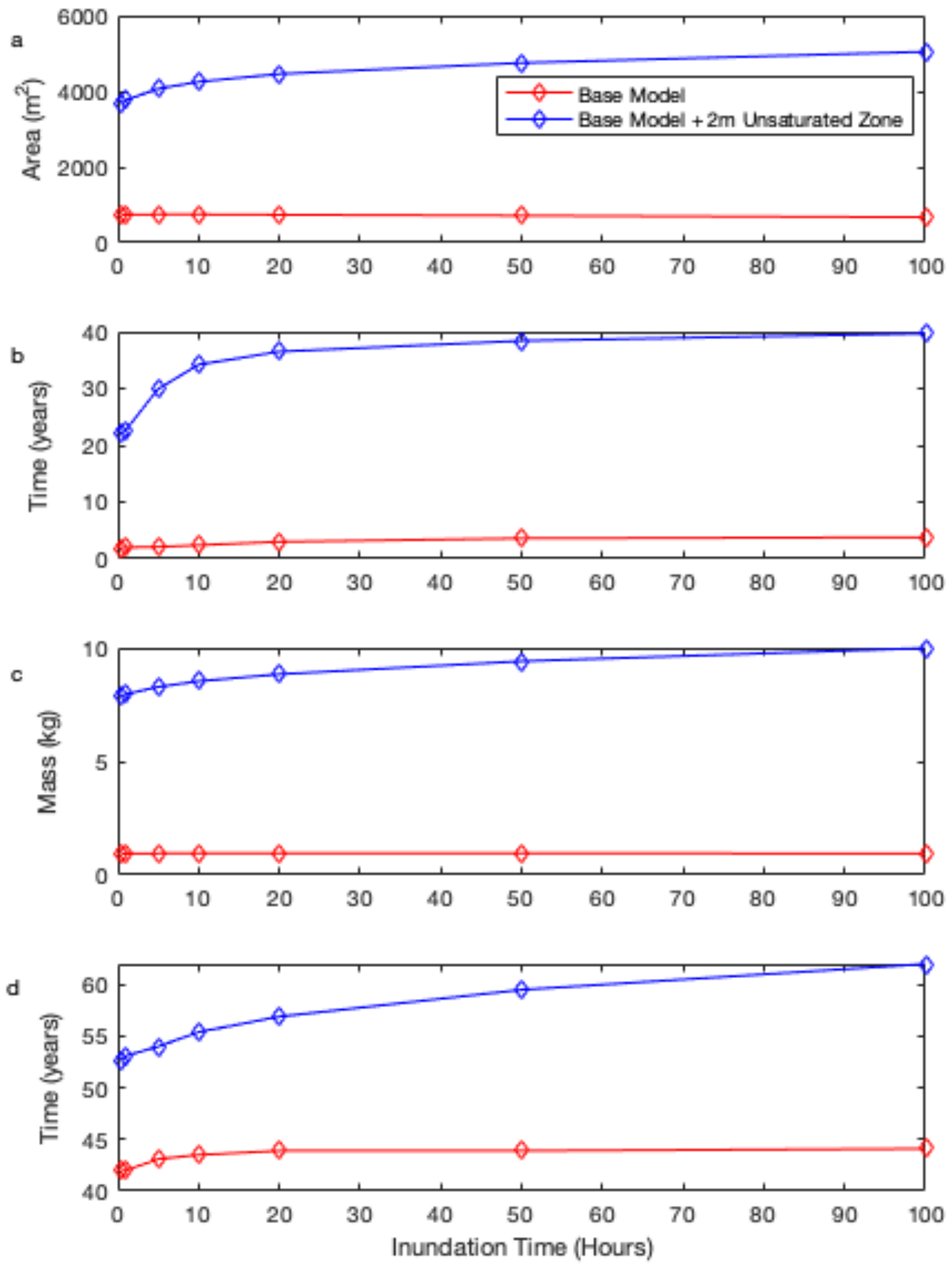

Figure 20: A comparison of indicators for different inundation times: (a) the maximum salinized area, (b) time needed to reach $10 \%$ of the maximum salinized area, (c) the maximum salt mass added, and (d) time needed for salt mass added return to pre-inundation conditions.

However, increasing the unsaturated zone thickness an additional two meters resulted in increasing salinized areas within the aquifer with longer inundation times (Figure 20a, blue 
line)). A 30-minute inundation only yielded a maximum salinized area of $3,665.5 \mathrm{~m}^{2}$. An additional 4.5 hours of inundation time (for a total inundation duration of five hours) increased the maximum salinized area by just over $400 \mathrm{~m}^{2}$. The longest inundation time had the highest maximum salinized area, reaching $5,052.6 \mathrm{~m}^{2}$, which was nearly 1.4 times higher than the shortest inundation duration. Since there was a larger unsaturated zone to fill, a longer inundation time is likely necessary to fill the unsaturated zone. However, the increasing salinized area may also result from the inundated seawater infiltrating laterally at the most landward extent of the specified pressure boundary. While the base model set results fit those of previous studies, inundation time is impactful with thicker unsaturated zones.

Increasing the inundation time had minimal impact on the time required to reduce the salinized area to $10 \%$ of its maximum, while it was impactful to the model set with two meters of additional unsaturated zone thickness (Figure 20b). For the base model set, the time required to reduce the maximum salinized area to $10 \%$ of its maximum ranged from 1.9 years for the 30 minute inundation to 3.8 years for the 100-hour inundation, less than a two-year difference. Due to the small difference in the maximum salinized area reached within each model for the base model set, the little variation observed within the times required could be expected. For the base $+2 \mathrm{~m}$ model set, the time required to reduce the maximum salinized area to $10 \%$ of its maximum increased sharply between 30-minute and 20-hour inundation times - from 22.1 years to 36.5 years, respectively. When the inundation time increased beyond 20 hours, the time required to reduce the maximum salinized area to $10 \%$ of the maximum did not increase as drastically. While the 20-hour inundation reduced in 36.5 years, the 100-hour inundation required 39.7 years to reduce its maximum, slightly over three hours longer. This indicates that once the aquifer is fully saturated, the rate of saline water infiltration is drastically reduced.

Varying the inundation time reveals little difference in the maximum salt mass added to the base model aquifer resulting from an overtopping event (Figure 20c, red line). Once the unsaturated zone of the base model became fully saturated, the infiltration rate slowed down and, thus, there was little salinity difference after saturation occurred, limiting the severity of contamination (Chui and Terry, 2012). However, as with the maximum salinized area, thicker unsaturated zones yielded increasing added salt masses as the duration of inundation increased (Figure 20c, blue 
line). The lowest maximum added salt mass to the base model occurred during the 30-minute inundation $(0.93 \mathrm{~kg})$, while the highest occurred at inundation times of ten, twenty, and fifty hours, though each was within $0.03 \mathrm{~kg}$ of the lowest inundation time. The model set with an additional two meters of unsaturated zone thickness allowed much more salt to enter the aquifer than the base model, but the salt mass also continued to increase as the inundation time increased. The maximum salt mass added to the base $+2 \mathrm{~m}$ models ranged from $7.87 \mathrm{~kg}$ for a 30 minute inundation to $9.99 \mathrm{~kg}$ for the 100 -hour inundation. The increasing total salt mass present in the models with a thicker unsaturated zone can be attributed to the need to fill a thicker unsaturated zone, as well as the lateral movement of the infiltrated seawater.

The times required to return the salt mass added to pre-inundation levels were similar for the base model set, with a range of only a few years between the least and greatest inundation times (Figure 20d, red line). The added salt mass for the model with an inundation time of 30 minutes returned to pre-inundation conditions after 42.0 years, while the 100-hour inundation model only needed slightly more than two additional years (44.1 years) to reach pre-inundation conditions. However, for the model set with an additional two meters of unsaturated zone thickness (Figure $20 \mathrm{~d}$, blue line), there was more variability in the times. The added salt mass for the model with an inundation time of 30 minutes returned to pre-inundation conditions after 52.7 years, while the 100-hour inundation model needed nearly a decade longer (62.0 years) to reach preinundation conditions. Due to the increase in added salt mass as the inundation times increased to models with thicker unsaturated zones, longer recovery periods were needed with models with greater inundation times, even though the recharge was the same for all models.

\subsubsection{Permeability}

Changes in permeability had an impact on the maximum salinized area the aquifer following inundation. Higher permeabilities facilitate the mass transport of salt during and following inundation, which allows for a larger saline plume to develop (Giambastiani, et al., 2017). As the permeability of the aquifer decreases, the migration of salt into the aquifer slows, limiting the amount of saltwater entering the system resulting from an overtopping event. Decreasing the permeability of the base model domain reduces the maximum salinized area within the aquifer following an overtopping event (Figure 21a). The base model allowed a saline plume to develop 

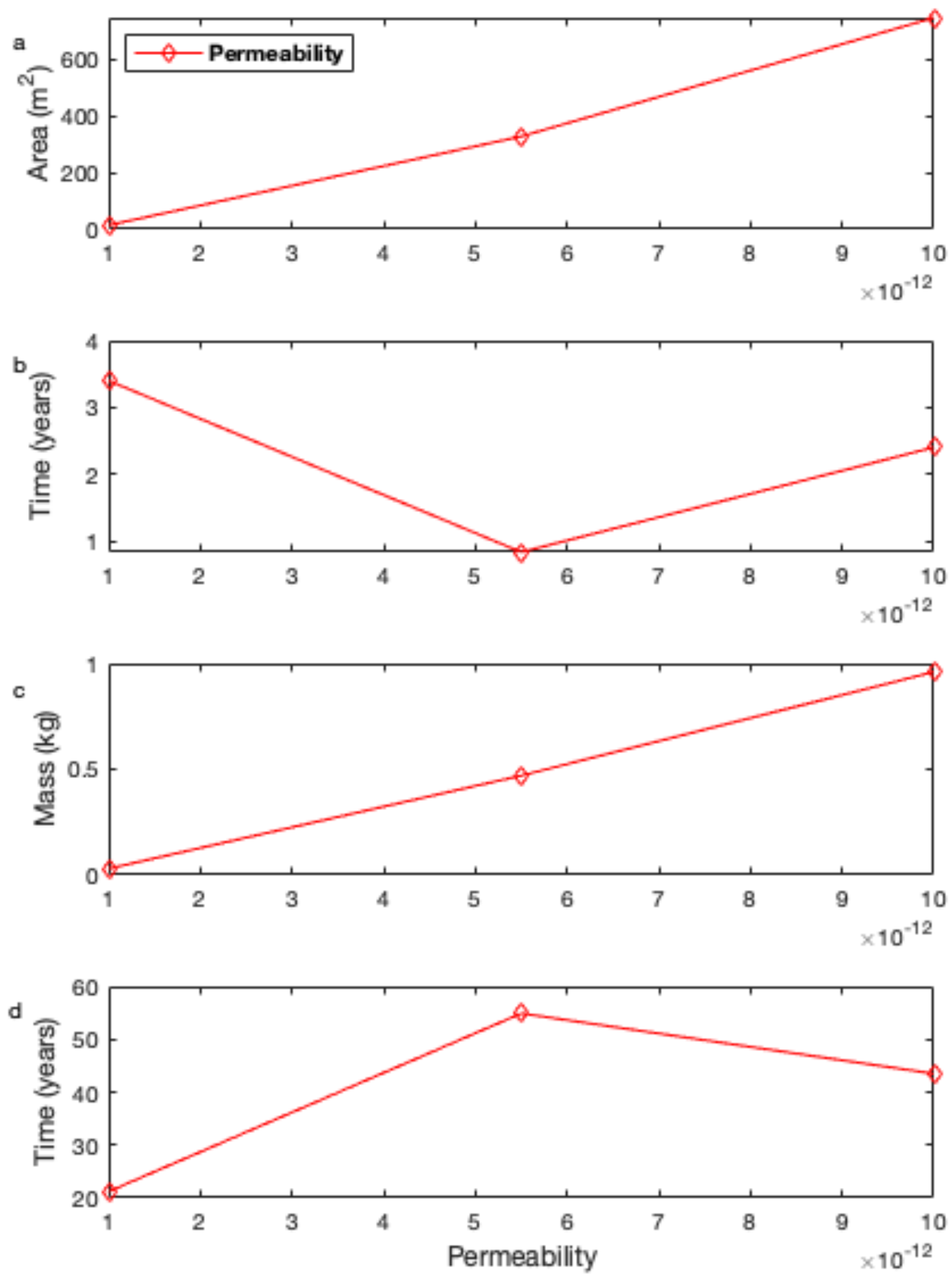

Figure 21: A comparison of indicators for different permeabilities: (a) the maximum salinized area, (b) time needed to reach $10 \%$ of the maximum salinized area, (c) the maximum salt mass added, and (d) time needed for salt mass added return to pre-inundation conditions. 
with a maximum salinized area of $747.7 \mathrm{~m}^{2}$. Decreasing the permeability to $5.5 \times 10^{-12} \mathrm{~m}^{2}$ nearly cut the maximum salinized area in half $\left(328.1 \mathrm{~m}^{2}\right)$, while one full order of magnitude smaller permeability only achieved a maximum salinized area of $14.3 \mathrm{~m}^{2}$, which was less than $2 \%$ of the maximum achieved for the base model. The lower permeability aquifers restrict the infiltration of inundated seawater, limiting the severity of contamination.

There was some variability in the amount of time required to reduce the salinized area to $10 \%$ of its maximum (Figure 21b). While both Gingerich et al. (2017) and Xiao et al. (2019) found that increased permeability within the subsurface allows inundated seawater to infiltrate much quicker and exhibit faster natural remediation of a contaminated aquifer than lower permeability values, our results showed only a general trend of decreasing reduction times with increased permeability (the $5.5 \times 10^{-12} \mathrm{~m}^{2}$ providing the outlier). The base model returned to $10 \%$ of its maximum value 2.4 years post-inundation, one year sooner than the model with a permeability of $1.0 \times 10^{-12} \mathrm{~m}^{2}$, which keeps with the expected outcome. However, the model with a permeability of $5.5 \times 10^{-12} \mathrm{~m}^{2}$ returned to $10 \%$ of its maximum value in under one-year post-inundation, much shorter than the other two models within the model set. In addition to having approximately half of the maximum salinized area, the mass centroid path of this model may explain the short duration of the reduction, as the trajectory of the centroid took a more direct path to the interface than the base model. Further models with permeabilities between the lowest and highest values used for this study may be necessary to determine if the low reduction time for the $5.5 \times 10^{-12} \mathrm{~m}^{2}$ is anomalous or part of larger inconsistencies.

The permeability is also influential in determining the amount of salt mass that is added to the aquifer following inundation, where decreased permeability lessens the salt mass that can enter the aquifer (Figure 21c). The base model featured the highest maximum added salt mass, 0.96 $\mathrm{kg}$, which decreased as the permeability was decreased to other models within the model set. The base model had more than two times the maximum added salt mass of the model with a permeability of $5.5 \times 10^{-12} \mathrm{~m}^{2}$ and had over 31 times the mass of the model with a permeability of $1.0 \times 10^{-12} \mathrm{~m}^{2}$. Permeability restricts the migration of the inundated seawater into the subsurface, resulting in less severe contamination to aquifers with lower permeability. 
Aquifers with lower permeabilities, while restricting the movement of inundated seawater into the subsurface and exhibiting less sever contamination, also restrict the movement of seawater that does infiltrate, thus extending the time required to flush the saline plume from the aquifer. The base model returned to pre-inundation conditions 43.5 years post-inundation, and the model with a permeability of $5.5 \times 10^{-12} \mathrm{~m}^{2}$ needed 54.9 years to reach pre-inundation levels, despite having half the added salt mass of the base model (Figure 21d). Although this generally agrees with the expected outcome, the model with a permeability of $1.0 \times 10^{-12} \mathrm{~m}^{2}$ took only 21.2 years to reach pre-inundation conditions, contradicting the idea that lower permeabilities require longer flushing times. However, this can be explained by the much lower added salt mass exhibited by the model, in comparison to the other models, as well as the centroid path, which hovered along the freshwater-saltwater interface. This is an indication that a threshold may exist in which aquifers with a certain low permeability not only limit the severity of saltwater contamination, but, because of the limited extent, return to pre-inundation conditions much quicker.

\subsection{Model Assumptions}

This groundwater modeling study makes several generalizations, assumptions, and simplifications that are inherent in groundwater modeling work. First, the model domain featured a constant slope without topographic features. While the constant slope of the model domain was aligned with those used in previous studies, the presence of topographic features would have impacted both the severity of contamination and subsequent recovery of the aquifer following an inundation event. Yu et al. (2016) showed that shore parallel topographic features, such as levees or dunes, act to prevent the landward movement of water, but can also restrict the seaward draining of inundated seawater once sea level falls. This causes depression storage on the barrier's landward side, which can add additional salt mass to the aquifer and prolong aquifer recovery. Incorporating these topographic features into the model domain would have added complexity, both in the construction of the model domain, but also in the number of simulations necessary to effectively model the depression storage.

Second, this model featured simulations that modeled an instantaneous overtopping event, followed by a sudden return to pre-inundation conditions. In real world settings, however, an overtopping event would likely feature a gradual sea-level rise followed by a gradual recession 
of the inundation seawater. Although a gradual runup to full inundation conditions could have been achieved through modification of the boundary conditions during the Inundation period, it would have added further complexity to the model.

Third, while the values for the model parameters used in this study were either typical of coastal aquifer systems or taken from previous studies, aquifer parameters were assigned as homogenous across both unsaturated and saturated zones. The real-world contexts, this would be rather unlikely, as heterogeneities exist, impacting the movement of fresh and saline groundwater throughout the aquifer. Additionally, the van Genuchten parameters were assumed using this model. Liu and Tokunaga (2019) used field measurements to parameterize their model, while this model relied upon the default SUTRA settings. The van Genuchten parameters are determined through either laboratory or field measurements. Since this is a generalized model not based upon an actual real-world site, actual laboratory or field measurements were not possible. The default parameters yielded an estimated capillary fringe height of $2.04 \mathrm{~m}$. However, pore size is influential in determining the actual height of the capillary fringe. Therefore, since the pore size of the unsaturated zone is not known, $2.04 \mathrm{~m}$ is likely the maximum height and is quite possibly lower.

Finally, while the creation of artificially thicker unsaturated zones through model domain design made comparison of parameters simpler, it did not allow for the parameters, such as the permeability or recharge, to be as impactful in the formation of the unsaturated zone.

Additionally, higher-elevation surge events were applied in models with thicker unsaturated zone

thicknesses to keep the horizontal inundation extent constant, but this resulted in greater pressure gradients associated with the inundation, which may have impacted the severity of contamination from the overtopping event.

\subsection{Suggestions for Future Work}

Though this was a generalized model based upon a real-world scenario, it provides insights into the impacts that the parameters of coastal aquifers can have on the severity of contamination within a coastal aquifer resulting from an overtopping event. Future research could expand upon the findings of this study to a model rectifying the simplifications and generalizations made for 
this model, such as incorporating topographic features, aquifer heterogeneities, or a gradual runup to overtopping to assess the severity of contamination following an overtopping event. Any of these, either individually or collectively, built into future models would provide even greater insights into the impact of overtopping events.

In more real-world contexts, future research could also use the results of this study to perform risk assessments for coastal cities, evaluate the vulnerability of a specific aquifer or region, and aide in the design of coastal protection structures. Any of these would be critical in further understanding how overtopping can impact coastal regions and may potentially lead to the implementation of policies designed to mitigate their effects.

\subsection{Societal Impacts}

Coastal regions feature dense, growing populations that can put a strain on freshwater resources already threatened by increasing severe coastal storms. Understanding how inundated seawater infiltrates and moves throughout a coastal aquifer is essential for managing freshwater resources. This study is the first to explicitly investigate the influence that unsaturated zone thickness has on the severity of saltwater contamination resulting from an overtopping event and the long-term impacts it can have. Though responses may vary, planners, managers, and society, as a whole, must prepare for saltwater intrusion and the devasting effects coastal storms can have on fresh groundwater resources.

The results of this study can be useful in the implementation of several approaches that have been suggested to mitigate the effects of overtopping on fresh groundwater in coastal aquifers. Coastal barriers, such as levees or dunes, have been constructed to prevent the landward movement of seawater. However, studies have shown that when breached, these barriers, and depressions landward of the barrier, prevent inundated seawater to recede, causing depression storage that can allow for additional saltwater contamination within the aquifer (Chui and Terry, 2012; Elsayad and Oumeraci, 2018; Mahmoodzadeh and Karamouz, 2017; Terry and Chui, 2012; Yang et al., 2013; Yu et al., 2016). Elsayad and Oumeraci (2018) suggested the construction of subsurface drainage systems, showing that they shortened remediation time and limited saltwater intrusion into the coastal aquifer. Due to the infrastructure associated with 
increasing populations in coastal zones, the presence of impervious surfaces in conjunction with subsurface drainage systems could aide in the mitigation of vertical saltwater intrusion into unconfined coastal aquifers.

Additionally, artificial recharge could be employed by planners and managers prior to the arrival of a coastal storm to decrease the thickness of the unsaturated zone and limit the severity of saltwater contamination resulting from an overtopping event. Artificial recharge is the humanmade process of increasing the freshwater infiltration into an aquifer, which raises the water table, decreasing the thickness of the unsaturated zone. This study has demonstrated that thinner unsaturated zones resulted in less severe contamination resulting from overtopping events. Therefore, with advanced meteorological forecasting, it may be feasible to mitigate the impacts of coastal storms by raising the water table artificially. In addition to preserving the water quality within the coastal aquifer, artificial recharge can lead to economic stability and increased crop yields in the agricultural sector (Bouri and Dhia, 2010). In addition to the aforementioned methods, the results presented in this study have implications for not only the water quality in coastal aquifers following an overtopping event but also for new, groundbreaking research that can lead to the implementation of policies, methods, and infrastructure aimed at protecting coastal fresh groundwater resources.

\section{Conclusions}

This study built numerical models and designed sensitivity analyses to investigate how unsaturated thickness, recharge rates, inundation duration, and aquifer permeability affected the response and recovery of coastal aquifers following overtopping events. The thickness of the unsaturated zone was an important factor in controlling the severity and flushing rate of saltwater contamination following an overtopping event, but several other factors were also found to be important. The unsaturated zone thickness defines the aquifer volume available for saline infiltration. High recharge rates and low permeability are also correlated with saline contamination severity following an overtopping event. High recharge rates and associated groundwater velocities cause more dilution of the plume and less salt mass to infiltration the aquifer. Aquifers with low permeability restrict the amount of salt that can recharge the aquifer and the speeds that introduced salt can flush through the system. Inundation duration was only 
meaningful in aquifers with unsaturated zones thicker than that of the base model - though this may be related to the simplistic handling of unsaturated flow in the SUTRA model.

Recovery of coastal aquifers to pre-inundation conditions depends on several factors, especially recharge. High recharge not only promotes dispersion and dilution of the salt mass that infiltrates the aquifer, but also provides higher groundwater velocities that flush the plume more quickly. Although the unsaturated zone thickness largely determines the amount of saltwater that can infiltrate an aquifer, our results have demonstrated that when different thicknesses are compared in systems with the same recharge, salt masses added as a result of inundation reduce to $10 \%$ of the maximum values in similar temporal scales. Permeability also impacts the time required for recovery to pre-inundation conditions - generally, higher-k aquifers flushed quickest, but aquifers with very low-k restrict infiltration and thus see very little impact from these relatively short overtopping events.

The most important findings are as follows:

1. Models with thicker unsaturated zones exhibited both a greater salt mass and salinized area $(>0.6 \mathrm{ppt})$ of saltwater to infiltrate the coastal aquifer post-inundation. Models with thicker unsaturated zones also required a longer amount of time for the saline plume to flush through the fresh aquifer.

2. Models with high recharge rates received less saline contamination and faster groundwater velocities helped the aquifer recover to pre-inundation conditions more quickly.

3. Aquifer contamination and flushing times were relatively insensitive to inundation durations.

4. High-k aquifers received more salt contamination (both mass and area), but recovery times were shorter in higher-k aquifers.

The results of this study have important implications for coastal groundwater quality. Vertical seawater infiltration and saltwater contamination following an overtopping event causes groundwater quality degradation within coastal aquifers that can last for decades, severely limiting the availability of freshwater for domestic, agricultural, or industrial usage. The long- 
term sustainability of coastal aquifers will continue to be a concern given the anticipated increase in the intensity and severity of coastal storms (IPCC, 2012). Therefore, these findings are useful to assess the vulnerability of coastal aquifers, which may help to identify coastal areas that may be at the most risk. This study could not only be the basis for future research on coastal aquifer vulnerability, but also the implementation of policies and practices designed to reduce the severity overtopping events have on the water quality in coastal aquifers. 


\section{References}

Alsumaiei, A. A., \& Bailey, R. T. (2018). Quantifying threats to groundwater resources in the Republic of Maldives Part I: Future rainfall patterns and sea-level rise. Hydrological processes, 32(9), 1137-1153.

Anderson Jr, W. P. (2002). Aquifer salinization from storm overwash. Journal of Coastal Research, 413-420.

Bouri, S., \& Dhia, H. B. (2010). A thirty-year artificial recharge experiment in a coastal aquifer in an arid zone: the Teboulba aquifer system (Tunisian Sahel). Comptes Rendus Geoscience, 342(1), 60-74.

Cardenas, M. B., Bennett, P. C., Zamora, P. B., Befus, K. M., Rodolfo, R. S., Cabria, H. B., \& Lapus, M. R. (2015). Devastation of aquifers from tsunami-like storm surge by Supertyphoon Haiyan. Geophysical Research Letters, 42(8), 2844-2851.

Chui, T. F. M., \& Terry, J. P. (2012). Modeling fresh water lens damage and recovery on atolls after storm-wave washover. Groundwater, 50(3), 412-420.

Chui, T. F. M., \& Terry, J. P. (2013). Influence of sea-level rise on freshwater lenses of different atoll island sizes and lens resilience to storm-induced salinization. Journal of Hydrology, 502, 18-26.

Elsayed, S. M., \& Oumeraci, H. (2018). Modelling and mitigation of storm-induced saltwater intrusion: Improvement of the resilience of coastal aquifers against marine floods by subsurface drainage. Environmental modelling \& software, 100, 252-277.

Fitts, C. R. (2002). Groundwater science. Elsevier.

Environmental Protection Agency. (2021, January 7). Secondary Drinking Water Standards: Guidance for Nuisance Chemicals. EPA. https://www.epa.gov/sdwa/secondary-drinkingwater-standards-guidance-nuisance-chemicals\#table.

Giambastiani, B. M., Colombani, N., Greggio, N., Antonellini, M., \& Mastrocicco, M. (2017). Coastal aquifer response to extreme storm events in Emilia-Romagna, Italy. Hydrological Processes, 31(8), 1613-1621.

Gingerich, S. B., Voss, C. I., \& Johnson, A. G. (2017). Seawater-flooding events and impact on freshwater lenses of low-lying islands: Controlling factors, basic management and mitigation. Journal of Hydrology, 551, 676-688.

Heiss, J. W., \& Michael, H. A. (2014). Saltwater-freshwater mixing dynamics in a sandy beach aquifer over tidal, spring-neap, and seasonal cycles. Water Resources Research, 50(8), 6747-6766. 
Heiss, J. W., Post, V. E., Laattoe, T., Russoniello, C. J., \& Michael, H. A. (2017). Physical controls on biogeochemical processes in intertidal zones of beach aquifers. Water Resources Research, 53(11), 9225-9244.

Holding, S., \& Allen, D. M. (2015). Wave overwash impact on small islands: Generalised observations of freshwater lens response and recovery for multiple hydrogeological settings. Journal of Hydrology, 529, 1324-1335.

Huizer, S., Karaoulis, M. C., Oude Essink, G. H. P., \& Bierkens, M. F. P. (2017). Monitoring and simulation of salinity changes in response to tide and storm surges in a sandy coastal aquifer system. Water Resources Research, 53(8), 6487-6509.

IPCC (2012). Managing the Risks of Extreme Events and Disasters to Advance Climate Change Adaptation. A Special Report of Working Groups I and II of the Intergovernmental Panel on Climate Change [Field, C.B., V. Barros, T.F. Stocker, D. Qin, D.J. Dokken, K.L. Ebi, M.D. Mastrandrea, K.J. Mach, G.-K. Plattner, S.K. Allen, M. Tignor, and P.M. Midgley (eds.)]. Cambridge University Press, Cambridge, UK, and New York, NY, USA, 582 pp.

Illangasekare, T., Tyler, S. W., Clement, T. P., Villholth, K. G., Perera, A. P. G. R. L., Obeysekera, J., ... \& Kaluarachchi, J. J. (2006). Impacts of the 2004 tsunami on groundwater resources in Sri Lanka. Water Resources Research, 42(5).

Klassen, J., \& Allen, D. M. (2017). Assessing the risk of saltwater intrusion in coastal aquifers. Journal of Hydrology, 551, 730-745.

Kovacs, S. E., Reinhardt, E. G., Stastna, M., Coutino, A., Werner, C., Collins, S. V., ... \& Le Maillot, C. (2017). Hurricane Ingrid and Tropical Storm Hanna's effects on the salinity of the coastal aquifer, Quintana Roo, Mexico. Journal of hydrology, 551, 703-714.

Liu, J., \& Tokunaga, T. (2019). Future risks of tsunami-induced seawater intrusion into unconfined coastal aquifers: insights from numerical simulations at Niijima Island, Japan. Water Resources Research, 55(12), 10082-10104.

Mahmoodzadeh, D., \& Karamouz, M. (2017). Influence of coastal flooding on seawater intrusion in coastal aquifers. In World Environmental and Water Resources Congress 2017 (pp. 66-79).

Mahmoodzadeh, D., \& Karamouz, M. (2019). Seawater intrusion in heterogeneous coastal aquifers under flooding events. Journal of Hydrology, 568, 1118-1130.

NOAA. (2015). Economics and Demographics. (n.d.). Retrieved from https:/coast.noaa.gov/states/fast-facts/economics-and-demographics.html.

Poehls, D. J., \& Smith, G. J. (Eds.). (2011). Encyclopedic dictionary of hydrogeology. Academic press. 
Provost, A. M., \& Voss, C. I. (2019). SUTRA, a Model for Saturated-Unsaturated, VariableDensity Groundwater Flow with Solute or Energy Transport-Documentation of Generalized Boundary Conditions, a Modified Implementation of Specified Pressures and Concentrations or Temperatures, and the Lake Capability (No. 6-A52). US Geological Survey.

Ranjan, P., Kazama, S., Sawamoto, M., \& Sana, A. (2009). Global scale evaluation of coastal fresh groundwater resources. Ocean \& Coastal Management, 52(3-4), 197-206.

Small, C., \& Nicholls, R. J. (2003). A global analysis of human settlement in coastal zones. Journal of coastal research, 584-599.

Terry, J. P. (2007). Tropical cyclones: climatology and impacts in the South Pacific. Springer Science \& Business Media.

Terry, J. P., \& Chui, T. F. M. (2012). Evaluating the fate of freshwater lenses on atoll islands after eustatic sea-level rise and cyclone-driven inundation: A modelling approach. Global and Planetary Change, 88, 76-84.

The Math Works, Inc. (2021). MATLAB (Version R2021a) [Computer software]. https://www.mathworks.com/

Winston, R. B. (2009). ModelMuse: a graphical user interface for MODFLOW-2005 and PHAST (p. 52). Reston, VA: US Geological Survey.

Xiao, H., Wang, D., Medeiros, S. C., Bilskie, M. V., Hagen, S. C., \& Hall, C. R. (2019). Exploration of the effects of storm surge on the extent of saltwater intrusion into the surficial aquifer in coastal east-central Florida (USA). Science of the total environment, 648, 1002-1017.

Yang, J., Graf, T., Herold, M., \& Ptak, T. (2013). Modelling the effects of tides and storm surges on coastal aquifers using a coupled surface-subsurface approach. Journal of contaminant hydrology, 149, 61-75.

Yang, J., Graf, T., \& Ptak, T. (2015). Sea level rise and storm surge effects in a coastal heterogeneous aquifer: a 2D modelling study in northern Germany. Grundwasser, 20(1), $39-51$.

Yang, J., Zhang, H., Yu, X., Graf, T., \& Michael, H. A. (2018). Impact of hydrogeological factors on groundwater salinization due to ocean-surge inundation. Advances in Water Resources, 111, 423-434.

Yu, X., Yang, J., Graf, T., Koneshloo, M., O'Neal, M. A., \& Michael, H. A. (2016). Impact of topography on groundwater salinization due to ocean surge inundation. Water Resources Research, 52(8), 5794-5812. 
Zhang, C., \& Shen, C. (2015). SutraLab (Release 0.11) [Computer Software]. GitHub. https://github.com/SUTRASET/SutraLab/releases/tag/0.11 


\section{Appendix A: Figures}

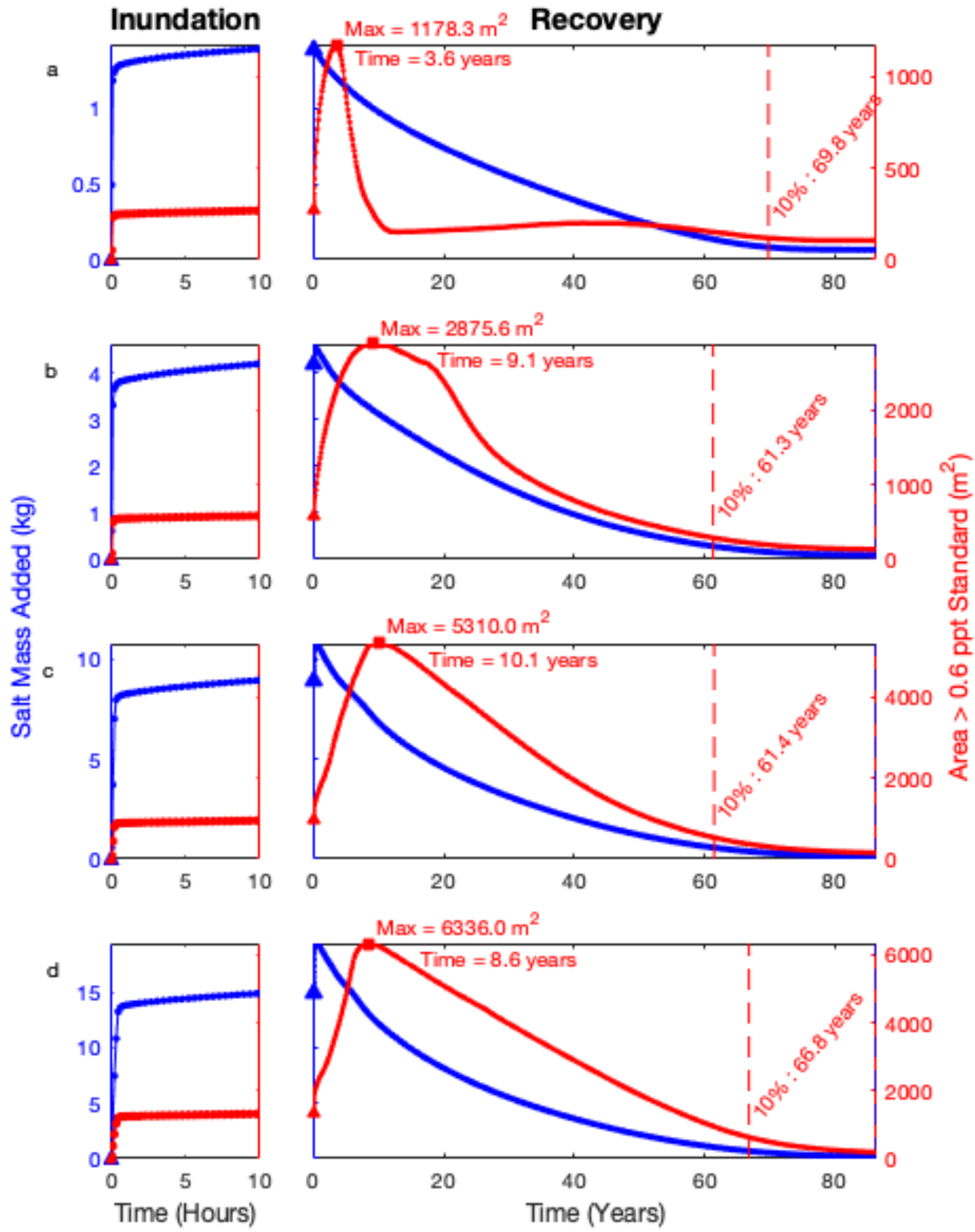

Appendix A; Figure 1: A comparison of model domains featuring the same recharge rate (5 cm/year) with different unsaturated zone thicknesses: (a) base model, (b) base model plus an additional 1 m of unsaturated zone thickness, (c) base model plus an additional $2 \mathrm{~m}$ of unsaturated zone thickness, and (d) base model plus an additional $3 \mathrm{~m}$ of unsaturated zone thickness. 'Max' values indicate maximum salinized area and 'Time' values are when maximum salinized area occurs. '10\%' indicates the time at which the maximum salinized area is reduced by $90 \%$. 

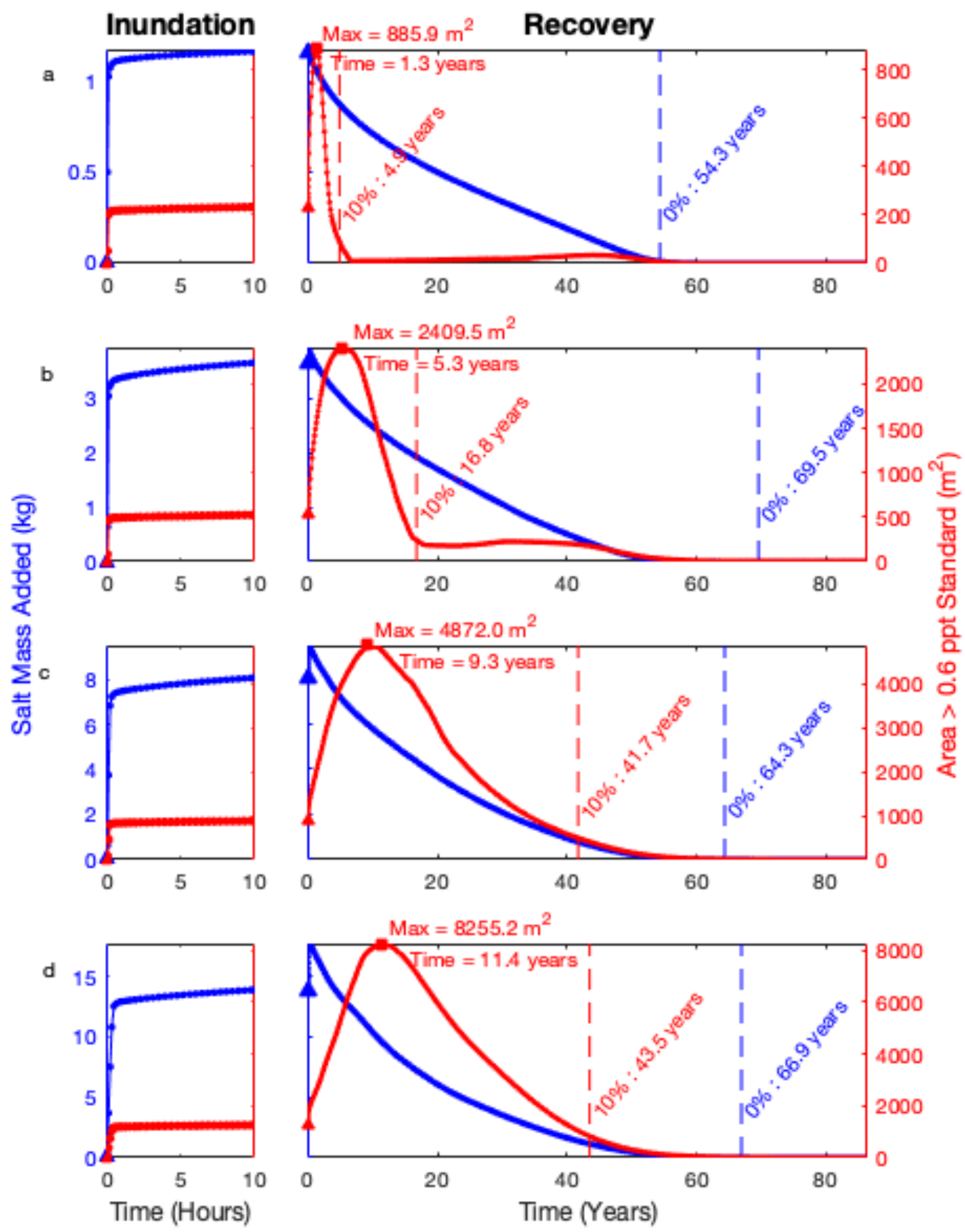

Appendix A; Figure 2: A comparison of model domains featuring the same recharge rate (10 $\mathrm{cm} / \mathrm{year})$ with different unsaturated zone thicknesses: (a) base model, (b) base model plus an additional $1 \mathrm{~m}$ of unsaturated zone thickness, (c) base model plus an additional $2 m$ of unsaturated zone thickness, and (d) base model plus an additional $3 \mathrm{~m}$ of unsaturated zone thickness. 'Max' values indicate maximum salinized area and 'Time' values are when maximum salinized area occurs. '10\%' indicates the time at which the maximum salinized area is reduced by $90 \%$. '0\%' is the time that the salt mass added returns to pre-inundation conditions. 

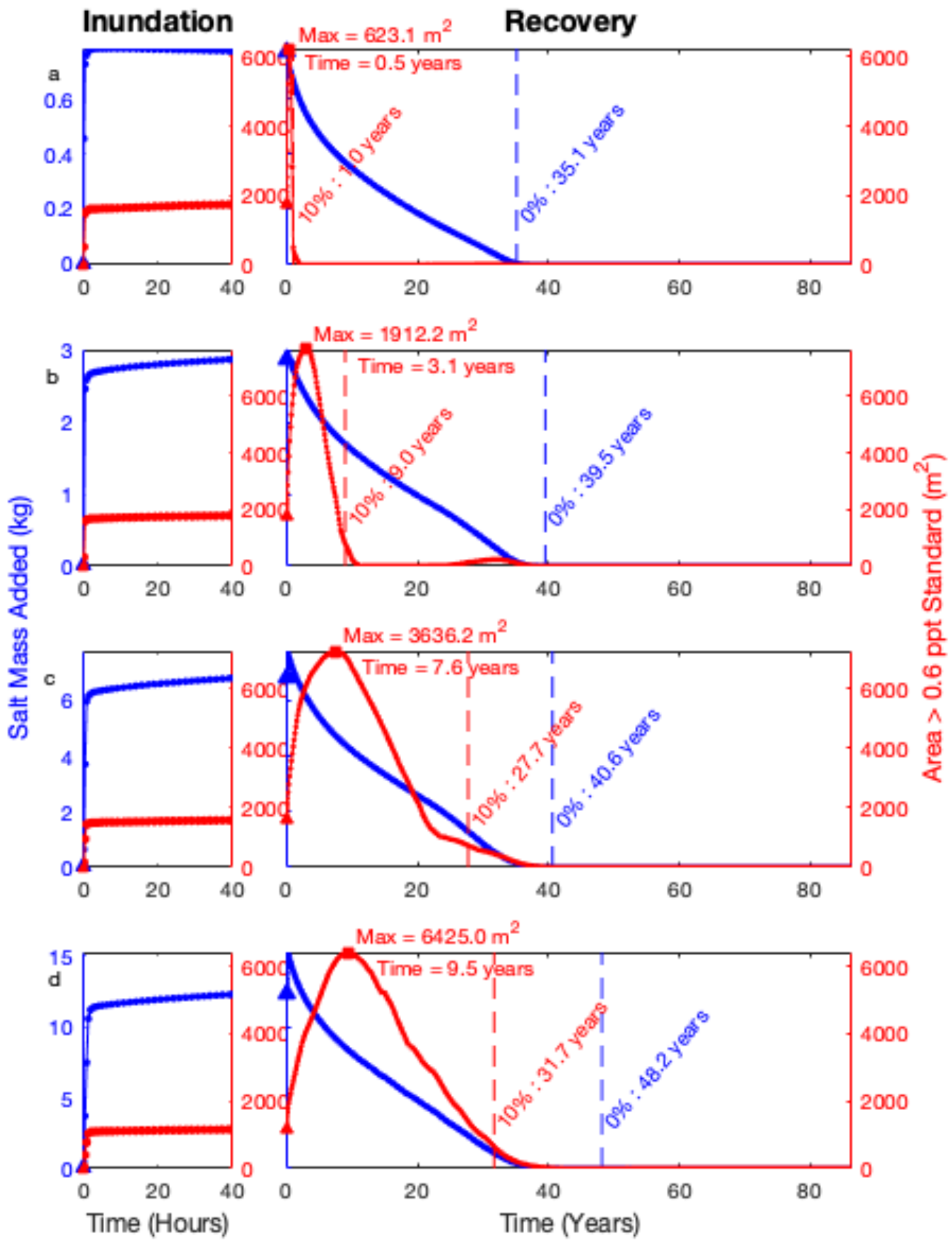

Appendix A; Figure 3: A comparison of model domains featuring the same recharge rate $(20 \mathrm{~cm} / \mathrm{year})$ with different unsaturated zone thicknesses: (a) base model, (b) base model plus an additional $1 \mathrm{~m}$ of unsaturated zone thickness, (c) base model plus an additional $2 m$ of unsaturated zone thickness, and (d) base model plus an additional $3 \mathrm{~m}$ of unsaturated zone thickness. 'Max' values indicate maximum salinized area and 'Time' values are when maximum salinized area occurs. '10\%' indicates the time at which the maximum salinized area is reduced by 90\%. '0\%' is the time that the salt mass added returns to pre-inundation conditions. 

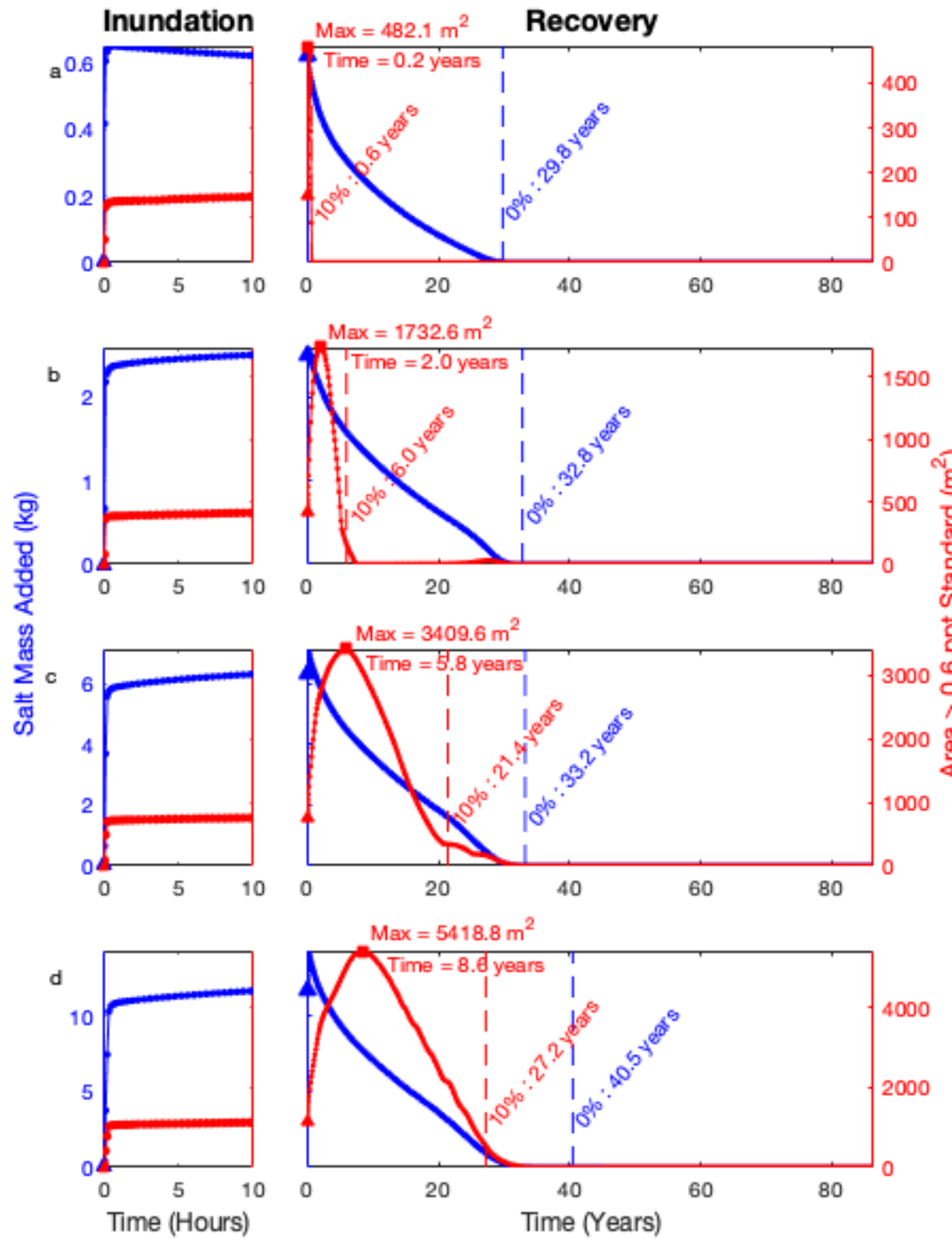

Appendix A; Figure 4: A comparison of model domains featuring the same recharge rate (25 $\mathrm{cm} / \mathrm{year})$ with different unsaturated zone thicknesses: (a) base model, (b) base model plus an additional 1 m of unsaturated zone thickness, (c) base model plus an additional $2 \mathrm{~m}$ of unsaturated zone thickness, and (d) base model plus an additional $3 \mathrm{~m}$ of unsaturated zone thickness. 'Max' values indicate maximum salinized area and 'Time' values are when maximum salinized area occurs. '10\%' indicates the time at which the maximum salinized area is reduced by $90 \%$. '0\%' is the time that the salt mass added returns to pre-inundation conditions. 


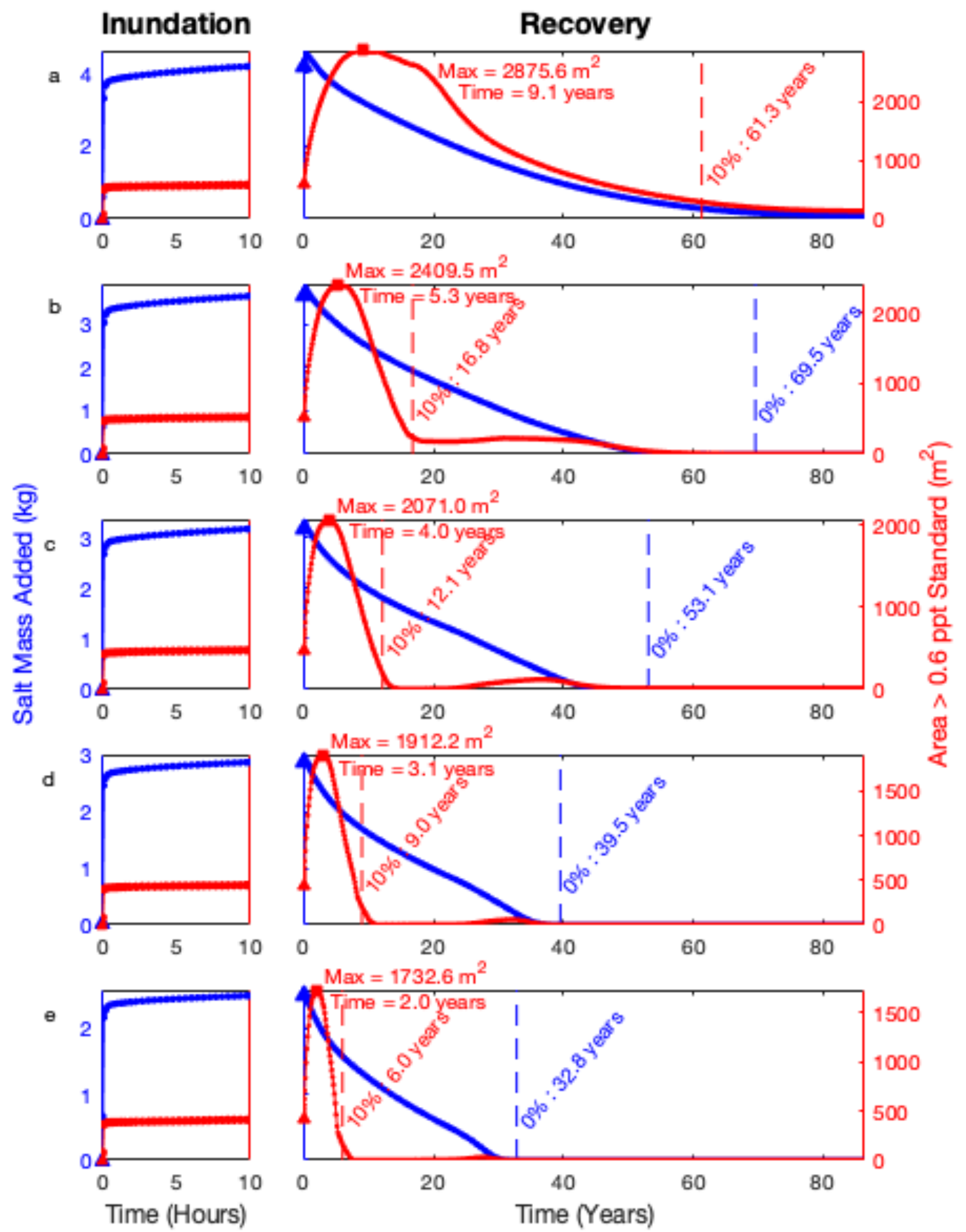

Appendix A, Figure 5: A comparison of the base model plus an additional meter of unsaturated zone thickness featuring different recharge rates: (a) $5 \mathrm{~cm} / y e a r$, (b) $10 \mathrm{~cm} / y e a r$ (c) $15 \mathrm{~cm} / y e a r$, and (d) $20 \mathrm{~cm} / y e a r$, and (e) 25 cm/year. 'Max' values indicate maximum salinized area and 'Time' values are when maximum salinized area occurs. '10\%' indicates the time at which the maximum salinized area is reduced by $90 \%$. '0\%' is the time that the salt mass added returns to pre-inundation conditions. 


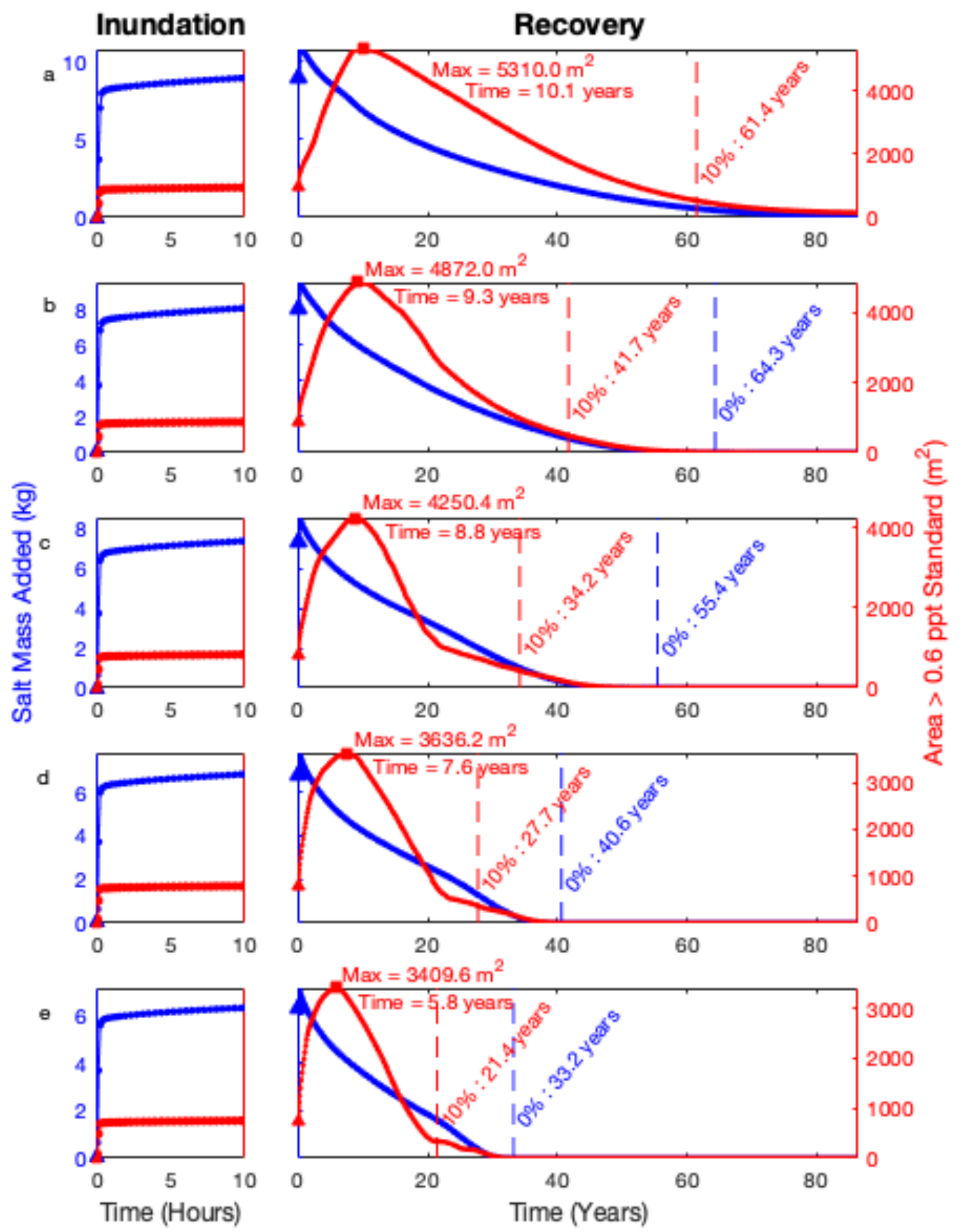

Appendix A, Figure 6: A comparison of the base model plus an additional 2 meters of unsaturated zone thickness featuring different recharge rates: (a) $5 \mathrm{~cm} / y e a r$, (b) $10 \mathrm{~cm} / y e a r$ (c) $15 \mathrm{~cm} / y e a r$, and (d) $20 \mathrm{~cm} / y e a r$, and (e) 25 cm/year. 'Max' values indicate maximum salinized area and 'Time' values are when maximum salinized area occurs. '10\%' indicates the time at which the maximum salinized area is reduced by $90 \%$. '0\%' is the time that the salt mass added returns to pre-inundation conditions. 


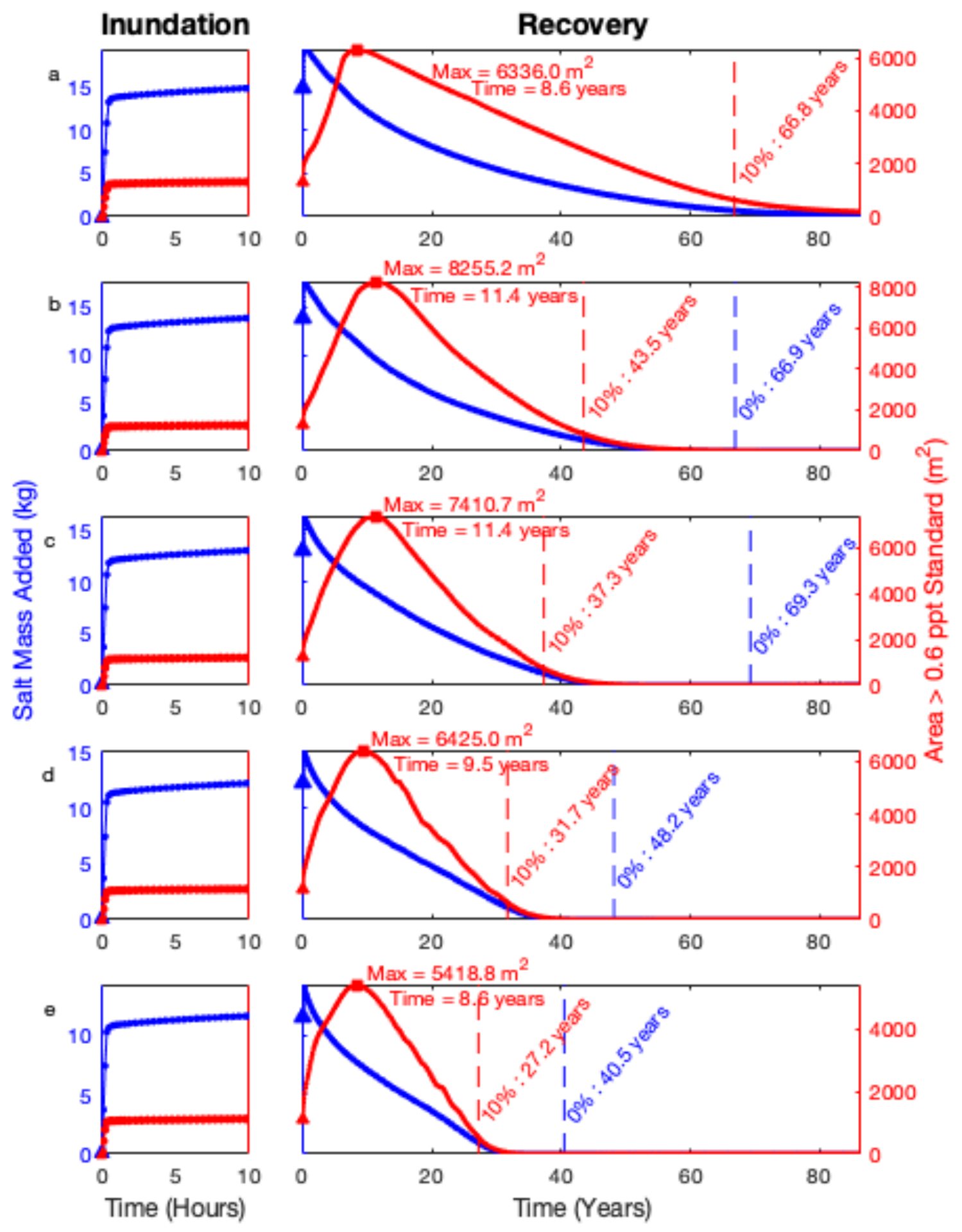

Appendix A, Figure 7: A comparison of the base model plus an additional 3 meters of unsaturated zone thickness featuring different recharge rates: (a) $5 \mathrm{~cm} / y e a r$, (b) $10 \mathrm{~cm} / y e a r$ (c) $15 \mathrm{~cm} / y e a r$, and (d) $20 \mathrm{~cm} / y e a r$, and (e) 25 cm/year. 'Max' values indicate maximum salinized area and 'Time' values are when maximum salinized area occurs. ' $10 \%$ ' indicates the time at which the maximum salinized area is reduced by $90 \%$. '0\%' is the time that the salt mass added returns to pre-inundation conditions. 


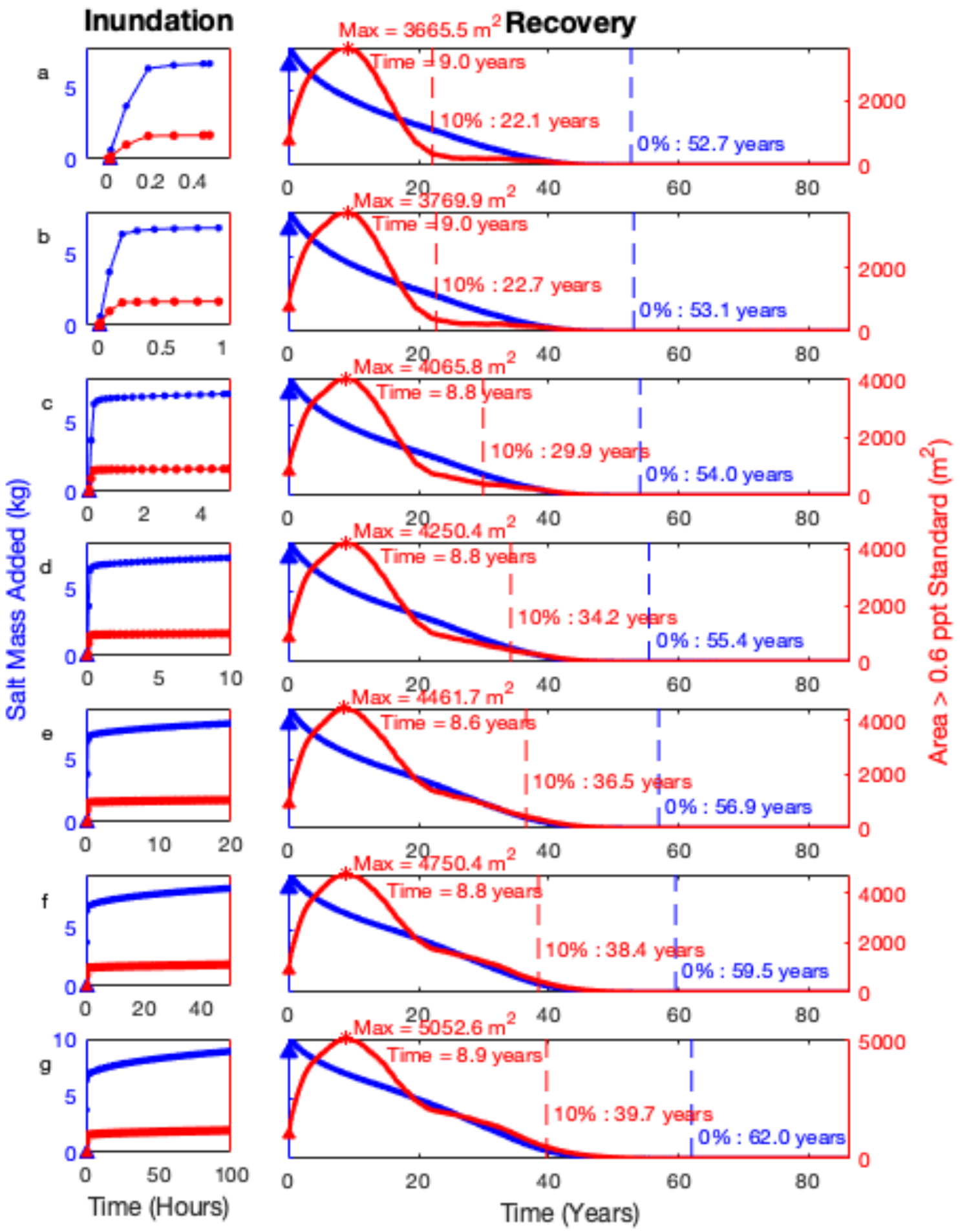

Appendix A, Figure 8: A comparison of different inundation times to the base model with an additional two meters of unsaturated zone thickness, featuring inundation times of: (a) 30 minutes, (b) 1 hour, (c) 5 hours, (d) 10 hours (base model), (e) 20 hours, (f) 50 hours, and (g) 100 hours. 'Max' values indicate maximum salinized area and 'Time' values are when maximum salinized area occurs. '10\%' indicates the time at which the maximum salinized area is reduced by $90 \%$. '0\%' is the time that the salt mass added returns to pre-inundation conditions. 

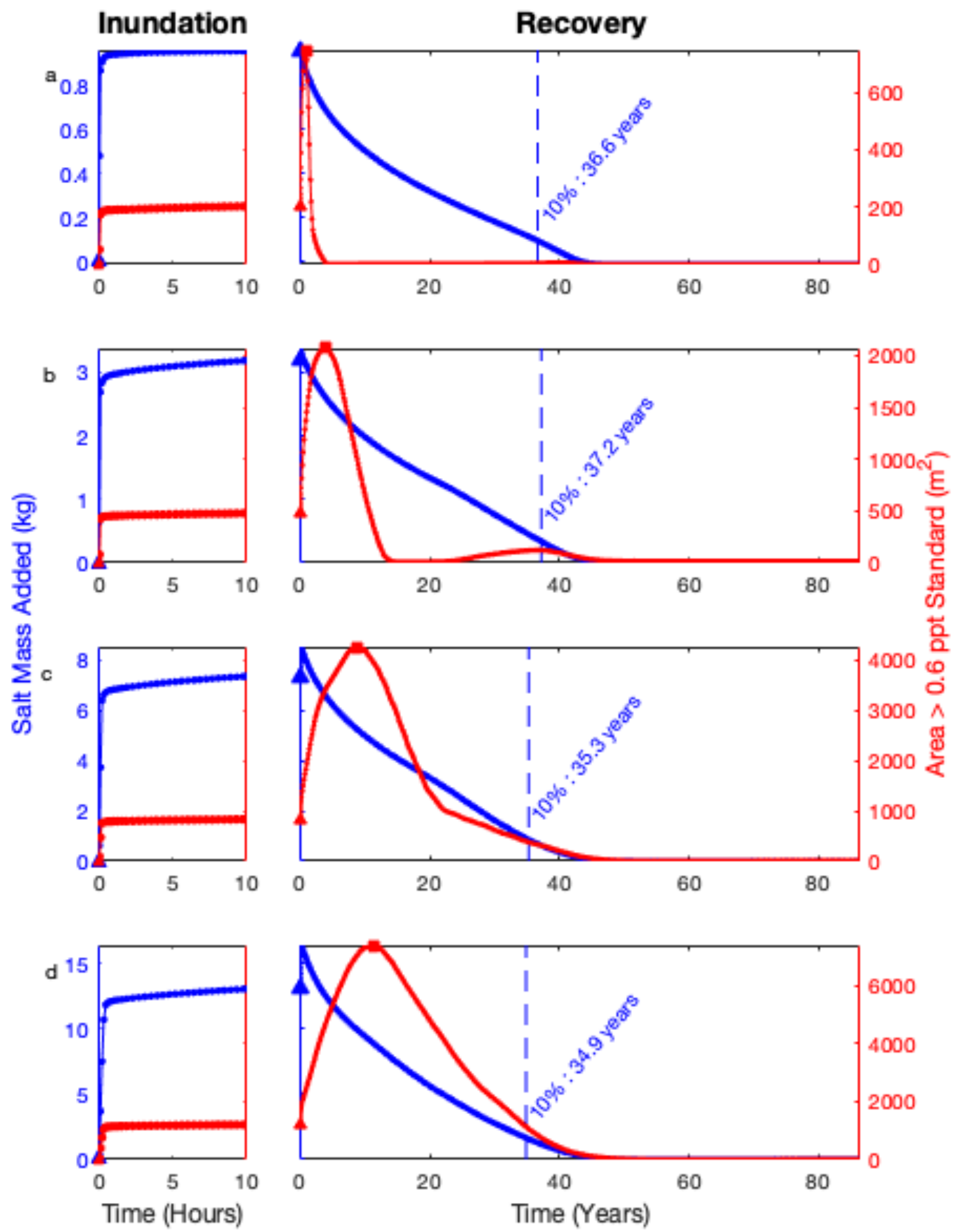

Appendix A; Figure 9: A comparison of model domains featuring the same recharge rate (15 $\mathrm{cm} / y$ ear) with different unsaturated zone thicknesses: (a) base model, (b) base model plus an additional 1 m of unsaturated zone

thickness, (c) base model plus an additional $2 \mathrm{~m}$ of unsaturated zone thickness, and (d) base model plus an additional $3 \mathrm{~m}$ of unsaturated zone thickness. Dashed blue line indicates the time at which the added salt mass reaches $10 \%$ of the maximum value. 


\section{Appendix B: Tables}

\begin{tabular}{|c|c|c|c|c|c|c|c|c|c|c|c|c|c|c|c|}
\hline Model Name & $\begin{array}{c}\text { Unsaturated } \\
\text { Zone } \\
\text { Thickness } \\
\end{array}$ & Recharge & $\begin{array}{c}\text { Longitudinal } \\
\text { Dispersivity }\end{array}$ & $\begin{array}{c}\text { Transverse } \\
\text { Dispersivity }\end{array}$ & Permeability & Porosity & $\begin{array}{c}\text { Seawater } \\
\text { Concentration }\end{array}$ & $\begin{array}{c}\text { Freshwater } \\
\text { Concentration }\end{array}$ & Gravity & $\begin{array}{c}\text { Land } \\
\text { Surface } \\
\text { Slope } \\
\end{array}$ & $\begin{array}{c}\text { Beachface } \\
\text { Slope }\end{array}$ & $\begin{array}{l}\text { Time } \\
\text { Steps } \\
\end{array}$ & $\begin{array}{c}\text { Time } \\
\text { Increment }\end{array}$ & Multiplier & Inundation \\
\hline Carpinello_Base_5 $5 \mathrm{~cm} \_\mathrm{k} 11 \_1$ _SteadyState & base & $5 \mathrm{~cm} / \mathrm{yr}$ & 0.5 & 0.05 & $1.0 \times 10^{-11}$ & 0.3 & 0.0357 & 0 & $9.8 \mathrm{~m} / \mathrm{s}^{2}$ & $0.01 \%$ & $7 \%$ & 36,500 & 259,200 & 1 & \\
\hline Carpinello_Base_5cm_k11_2_SteadyState & base & $5 \mathrm{~cm} / \mathrm{yr}$ & 0.5 & 0.05 & $1.0 \times 10^{-11}$ & 0.3 & 0.0357 & 0 & $9.8 \mathrm{~m} / \mathrm{s}^{2}$ & $0.01 \%$ & $7 \%$ & 36,500 & 259,200 & 1 & \\
\hline Carpinello_Base_5 $\mathrm{cm} \_\mathrm{k} 11 \_2$ Inundation & base & $5 \mathrm{~cm} / \mathrm{yr}$ & 0.5 & 0.05 & $1.0 \times 10^{-11}$ & 0.3 & 0.0357 & 0 & $9.8 \mathrm{~m} / \mathrm{s}^{2}$ & $0.01 \%$ & $7 \%$ & 147 & 60 & 1.03 & $10 \mathrm{hr}$ \\
\hline Carpinello_Base_5cm_k11_2_Recovery & base & $5 \mathrm{~cm} / \mathrm{yr}$ & 0.5 & 0.05 & $1.0 \times 10^{-11}$ & 0.3 & 0.0357 & 0 & $9.8 \mathrm{~m} / \mathrm{s}^{2}$ & $0.01 \%$ & $7 \%$ & 16,000 & 360 & 1.02 & \\
\hline Carpinello_Base_10 $\mathrm{cm} \_\mathrm{k} 11 \_1$ _SteadyState & base & $10 \mathrm{~cm} / \mathrm{yr}$ & 0.5 & 0.05 & $1.0 \times 10^{-11}$ & 0.3 & 0.0357 & 0 & $9.8 \mathrm{~m} / \mathrm{s}^{2}$ & $0.01 \%$ & $7 \%$ & 36,500 & 259,200 & 1 & \\
\hline Carpinello_Base_10 $\mathrm{cm} \_k 11 \_2$ SSteadyState & base & $10 \mathrm{~cm} / \mathrm{yr}$ & 0.5 & 0.05 & $1.0 \times 10^{-11}$ & 0.3 & 0.0357 & 0 & $9.8 \mathrm{~m} / \mathrm{s}^{2}$ & $0.01 \%$ & $7 \%$ & 36,500 & 259,200 & 1 & \\
\hline Carpinello_Base_10 $\mathrm{cm} \_\mathrm{k} 11 \_2$ Inundation & base & $10 \mathrm{~cm} / \mathrm{yr}$ & 0.5 & 0.05 & $1.0 \times 10^{-11}$ & 0.3 & 0.0357 & 0 & $9.8 \mathrm{~m} / \mathrm{s}^{2}$ & $0.01 \%$ & $7 \%$ & 147 & 60 & 1.03 & $10 \mathrm{hr}$ \\
\hline Carpinello_Base_10cm_k11_2_Recovery & base & $10 \mathrm{~cm} / \mathrm{yr}$ & 0.5 & 0.05 & $1.0 \times 10^{-11}$ & 0.3 & 0.0357 & 0 & $9.8 \mathrm{~m} / \mathrm{s}^{2}$ & $0.01 \%$ & $7 \%$ & 16,000 & 360 & 1.02 & \\
\hline Carpinello_Base_15cm_k11_1_SteadyState & base & $15 \mathrm{~cm} / \mathrm{yr}$ & 0.5 & 0.05 & $1.0 \times 10^{-11}$ & 0.3 & 0.0357 & 0 & $9.8 \mathrm{~m} / \mathrm{s}^{2}$ & $0.01 \%$ & $7 \%$ & 36,500 & 259,200 & 1 & \\
\hline Carpinello_Base_15cm_k11_2_SteadyState & base & $15 \mathrm{~cm} / \mathrm{yr}$ & 0.5 & 0.05 & $1.0 \times 10^{-11}$ & 0.3 & 0.0357 & 0 & $9.8 \mathrm{~m} / \mathrm{s}^{2}$ & $0.01 \%$ & $7 \%$ & 36,500 & 259,200 & 1 & \\
\hline Carpinello_Base_15cm_k11_2_Inundation & base & $15 \mathrm{~cm} / \mathrm{yr}$ & 0.5 & 0.05 & $1.0 \times 10^{-11}$ & 0.3 & 0.0357 & 0 & $9.8 \mathrm{~m} / \mathrm{s}^{2}$ & $0.01 \%$ & $7 \%$ & 147 & 60 & 1.03 & $10 \mathrm{hr}$ \\
\hline Carpinello_Base_15cm_k11_2_Recovery & base & $15 \mathrm{~cm} / \mathrm{yr}$ & 0.5 & 0.05 & $1.0 \times 10^{-11}$ & 0.3 & 0.0357 & 0 & $9.8 \mathrm{~m} / \mathrm{s}^{2}$ & $0.01 \%$ & $7 \%$ & 16,000 & 360 & 1.02 & \\
\hline Carpinello_Base_20cm_k11_1_SteadyState & base & $20 \mathrm{~cm} / \mathrm{yr}$ & 0.5 & 0.05 & $1.0 \times 10^{-11}$ & 0.3 & 0.0357 & 0 & $9.8 \mathrm{~m} / \mathrm{s}^{2}$ & $0.01 \%$ & $7 \%$ & 36,500 & 259,200 & 1 & \\
\hline Carpinello_Base_20 $\mathrm{cm} \_\mathrm{k} 11 \_2$ SteadyState & base & $20 \mathrm{~cm} / \mathrm{yr}$ & 0.5 & 0.05 & $1.0 \times 10^{-11}$ & 0.3 & 0.0357 & 0 & $9.8 \mathrm{~m} / \mathrm{s}^{2}$ & $0.01 \%$ & $7 \%$ & 36,500 & 259,200 & 1 & \\
\hline Carpinello_Base_20 $\mathrm{cm} \_\mathrm{k} 11 \_2$ Inundation & base & $20 \mathrm{~cm} / \mathrm{yr}$ & 0.5 & 0.05 & $1.0 \times 10^{-11}$ & 0.3 & 0.0357 & 0 & $9.8 \mathrm{~m} / \mathrm{s}^{2}$ & $0.01 \%$ & $7 \%$ & 147 & 60 & 1.03 & $10 \mathrm{hr}$ \\
\hline Carpinello_Base_20cm_k11_2_Recovery & base & $20 \mathrm{~cm} / \mathrm{yr}$ & 0.5 & 0.05 & $1.0 \times 10^{-11}$ & 0.3 & 0.0357 & 0 & $9.8 \mathrm{~m} / \mathrm{s}^{2}$ & $0.01 \%$ & $7 \%$ & 16,000 & 360 & 1.02 & \\
\hline Carpinello_Base_25cm_k11_1_SteadyState & base & $25 \mathrm{~cm} / \mathrm{yr}$ & 0.5 & 0.05 & $1.0 \times 10^{-11}$ & 0.3 & 0.0357 & 0 & $9.8 \mathrm{~m} / \mathrm{s}^{2}$ & $0.01 \%$ & $7 \%$ & 36,500 & 259,200 & 1 & \\
\hline Carpinello_Base_25 $2 \mathrm{~cm}$ k $11 \_2$ SteadyState & base & $25 \mathrm{~cm} / \mathrm{yr}$ & 0.5 & 0.05 & $1.0 \times 10^{-11}$ & 0.3 & 0.0357 & 0 & $9.8 \mathrm{~m} / \mathrm{s}^{2}$ & $0.01 \%$ & $7 \%$ & 36,500 & 259,200 & 1 & \\
\hline Carpinello_Base_25cm_k11_2_Inundation & base & $25 \mathrm{~cm} / \mathrm{yr}$ & 0.5 & 0.05 & $1.0 \times 10^{-11}$ & 0.3 & 0.0357 & 0 & $9.8 \mathrm{~m} / \mathrm{s}^{2}$ & $0.01 \%$ & $7 \%$ & 147 & 60 & 1.03 & $10 \mathrm{hr}$ \\
\hline Carpinello_Base_25cm_k11_2_Recovery & base & $25 \mathrm{~cm} / \mathrm{yr}$ & 0.5 & 0.05 & $1.0 \times 10^{-11}$ & 0.3 & 0.0357 & 0 & $9.8 \mathrm{~m} / \mathrm{s}^{2}$ & $0.01 \%$ & $7 \%$ & 16,000 & 360 & 1.02 & \\
\hline
\end{tabular}

Table 1: Base Model Simulations 


\begin{tabular}{|c|c|c|c|c|c|c|c|c|c|c|c|c|c|c|c|}
\hline Model Name & $\begin{array}{c}\text { Unsaturated } \\
\text { Zone } \\
\text { Thickness } \\
\end{array}$ & Recharge & $\begin{array}{c}\text { Longitudinal } \\
\text { Dispersivity } \\
\end{array}$ & $\begin{array}{c}\text { Transverse } \\
\text { Dispersivity }\end{array}$ & Permeability & Porosity & $\begin{array}{c}\text { Seawater } \\
\text { Concentration } \\
\end{array}$ & $\begin{array}{c}\text { Freshwater } \\
\text { Concentration }\end{array}$ & Gravity & $\begin{array}{c}\text { Land } \\
\text { Surface } \\
\text { Slope } \\
\end{array}$ & $\begin{array}{c}\text { Beachface } \\
\text { Slope }\end{array}$ & $\begin{array}{l}\text { Time } \\
\text { Steps } \\
\end{array}$ & $\begin{array}{c}\text { Time } \\
\text { Increment }\end{array}$ & Multiplier & Inundatior \\
\hline $\begin{array}{l}\text { Carpinello_Base1_5cm_k11_1_SteadyState } \\
\end{array}$ & Base $+1 \mathrm{~m}$ & $5 \mathrm{~cm} / \mathrm{yr}$ & 0.5 & 0.05 & $1.0 \times 10^{-11}$ & 0.3 & 0.0357 & 0 & $9.8 \mathrm{~m} / \mathrm{s}^{2}$ & $0.01 \%$ & $7 \%$ & 36,500 & 86,400 & 1 & \\
\hline $\begin{array}{l}\text { Carpinello_Base1_5cm_k11_2_SteadyState } \\
\end{array}$ & Base $+1 \mathrm{~m}$ & $5 \mathrm{~cm} / \mathrm{yr}$ & 0.5 & 0.05 & $1.0 \times 10^{-11}$ & 0.3 & 0.0357 & 0 & $9.8 \mathrm{~m} / \mathrm{s}^{2}$ & $0.01 \%$ & $7 \%$ & 36,500 & 86,400 & 1 & \\
\hline $\begin{array}{l}\text { Carpinello_Base1_5cm_k11_3_SteadyState } \\
\end{array}$ & Base $+1 \mathrm{~m}$ & $5 \mathrm{~cm} / \mathrm{yr}$ & 0.5 & 0.05 & $1.0 \times 10^{-11}$ & 0.3 & 0.0357 & 0 & $9.8 \mathrm{~m} / \mathrm{s}^{2}$ & $0.01 \%$ & $7 \%$ & 36,500 & 86,400 & 1 & \\
\hline Carpinello_Base1_5cm_k11_4_SteadyState & Base $+1 \mathrm{~m}$ & $5 \mathrm{~cm} / \mathrm{yr}$ & 0.5 & 0.05 & $1.0 \times 10^{-11}$ & 0.3 & 0.0357 & 0 & $9.8 \mathrm{~m} / \mathrm{s}^{2}$ & $0.01 \%$ & $7 \%$ & 36,500 & 86,400 & 1 & \\
\hline $\begin{array}{l}\text { Carpinello_Base1_5cm_k11_5_SteadyState } \\
\end{array}$ & Base $+1 \mathrm{~m}$ & $5 \mathrm{~cm} / \mathrm{yr}$ & 0.5 & 0.05 & $1.0 \times 10^{-11}$ & 0.3 & 0.0357 & 0 & $9.8 \mathrm{~m} / \mathrm{s}^{2}$ & $0.01 \%$ & $7 \%$ & 36,500 & 86,400 & 1 & \\
\hline $\begin{array}{l}\text { Carpinello_Base1_5cm_k11_6_SteadyState } \\
\end{array}$ & Base $+1 \mathrm{~m}$ & $5 \mathrm{~cm} / \mathrm{yr}$ & 0.5 & 0.05 & $1.0 \times 10^{-11}$ & 0.3 & 0.0357 & 0 & $9.8 \mathrm{~m} / \mathrm{s}^{2}$ & $0.01 \%$ & $7 \%$ & 36,500 & 86,400 & 1 & \\
\hline $\begin{array}{l}\text { Carpinello_Base1_5cm_k11_6_Inundation } \\
\end{array}$ & Base $+1 \mathrm{~m}$ & $5 \mathrm{~cm} / \mathrm{yr}$ & 0.5 & 0.05 & $1.0 \times 10^{-11}$ & 0.3 & 0.0357 & 0 & $9.8 \mathrm{~m} / \mathrm{s}^{2}$ & $0.01 \%$ & $7 \%$ & 147 & 60 & 1.03 & $10 \mathrm{hr}$ \\
\hline Carpinello_Base1_5cm_k11_6_Recovery & Base $+1 \mathrm{~m}$ & $5 \mathrm{~cm} / \mathrm{yr}$ & 0.5 & 0.05 & $1.0 \times 10^{-11}$ & 0.3 & 0.0357 & 0 & $9.8 \mathrm{~m} / \mathrm{s}^{2}$ & $0.01 \%$ & $7 \%$ & 16,000 & 360 & 1.02 & \\
\hline Carpinello_Base1_10cm_k11_1_SteadyState & Base $+1 \mathrm{~m}$ & $10 \mathrm{~cm} / \mathrm{yr}$ & 0.5 & 0.05 & $1.0 \times 10^{-11}$ & 0.3 & 0.0357 & 0 & $9.8 \mathrm{~m} / \mathrm{s}^{2}$ & $0.01 \%$ & $7 \%$ & 36,500 & 86,400 & 1 & \\
\hline 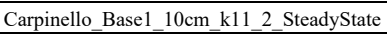 & Base $+1 \mathrm{~m}$ & $10 \mathrm{~cm} / \mathrm{yr}$ & 0.5 & 0.05 & $1.0 \times 10^{-11}$ & 0.3 & 0.0357 & 0 & $9.8 \mathrm{~m} / \mathrm{s}^{2}$ & $0.01 \%$ & $7 \%$ & 36,500 & 86,400 & 1 & \\
\hline 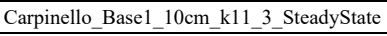 & Base $+1 \mathrm{~m}$ & $10 \mathrm{~cm} / \mathrm{yr}$ & 0.5 & 0.05 & $1.0 \times 10^{-11}$ & 0.3 & 0.0357 & 0 & $9.8 \mathrm{~m} / \mathrm{s}^{2}$ & $0.01 \%$ & $7 \%$ & 36,500 & 86,400 & 1 & \\
\hline Carpinello_Base1_10cm_k11_4_SteadyState & Base $+1 \mathrm{~m}$ & $10 \mathrm{~cm} / \mathrm{yr}$ & 0.5 & 0.05 & $1.0 \times 10^{-11}$ & 0.3 & 0.0357 & 0 & $9.8 \mathrm{~m} / \mathrm{s}^{2}$ & $0.01 \%$ & $7 \%$ & 36,500 & 86,400 & 1 & \\
\hline 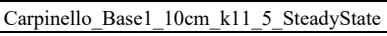 & Base $+1 \mathrm{~m}$ & $10 \mathrm{~cm} / \mathrm{yr}$ & 0.5 & 0.05 & $1.0 \times 10^{-11}$ & 0.3 & 0.0357 & 0 & $9.8 \mathrm{~m} / \mathrm{s}^{2}$ & $0.01 \%$ & $7 \%$ & 36,500 & 86,400 & 1 & \\
\hline $\begin{array}{l}\text { Carpinello_Base1_10cm_k11_6_SteadyState } \\
\end{array}$ & Base $+1 \mathrm{~m}$ & $10 \mathrm{~cm} / \mathrm{yr}$ & 0.5 & 0.05 & $1.0 \times 10^{-11}$ & 0.3 & 0.0357 & 0 & $9.8 \mathrm{~m} / \mathrm{s}^{2}$ & $0.01 \%$ & $7 \%$ & 36,500 & 86,400 & 1 & \\
\hline $\begin{array}{l}\text { Carpinello_Base1_10cm_k11_6_Inundation } \\
\end{array}$ & Base $+1 \mathrm{~m}$ & $10 \mathrm{~cm} / \mathrm{yr}$ & 0.5 & 0.05 & $1.0 \times 10^{-11}$ & 0.3 & 0.0357 & 0 & $9.8 \mathrm{~m} / \mathrm{s}^{2}$ & $0.01 \%$ & $7 \%$ & 147 & 60 & 1.03 & $10 \mathrm{hr}$ \\
\hline $\begin{array}{l}\text { Carpinello_Base1_10cm_k11_6_Recovery } \\
\end{array}$ & Base $+1 \mathrm{~m}$ & $10 \mathrm{~cm} / \mathrm{yr}$ & 0.5 & 0.05 & $1.0 \times 10^{-11}$ & 0.3 & 0.0357 & 0 & $9.8 \mathrm{~m} / \mathrm{s}^{2}$ & $0.01 \%$ & $7 \%$ & 16,000 & 360 & 1.02 & \\
\hline $\begin{array}{l}\text { Carpinello_Base1_15cm_k11_1_SteadyState } \\
\end{array}$ & Base $+1 \mathrm{~m}$ & $15 \mathrm{~cm} / \mathrm{yr}$ & 0.5 & 0.05 & $1.0 \times 10^{-11}$ & 0.3 & 0.0357 & 0 & $9.8 \mathrm{~m} / \mathrm{s}^{2}$ & $0.01 \%$ & $7 \%$ & 36,500 & 86,400 & 1 & \\
\hline Carpinello_Base1_15cm_k11_2_SteadyState & Base $+1 \mathrm{~m}$ & $15 \mathrm{~cm} / \mathrm{yr}$ & 0.5 & 0.05 & $1.0 \times 10^{-11}$ & 0.3 & 0.0357 & 0 & $9.8 \mathrm{~m} / \mathrm{s}^{2}$ & $0.01 \%$ & $7 \%$ & 36,500 & 86,400 & 1 & \\
\hline $\begin{array}{l}\text { Carpinello_Base1_15cm_k11_3_SteadyState } \\
\end{array}$ & Base $+1 \mathrm{~m}$ & $15 \mathrm{~cm} / \mathrm{yr}$ & 0.5 & 0.05 & $1.0 \times 10^{-11}$ & 0.3 & 0.0357 & 0 & $9.8 \mathrm{~m} / \mathrm{s}^{2}$ & $0.01 \%$ & $7 \%$ & 36,500 & 86,400 & 1 & \\
\hline Carpinello_Base1_15cm_k11_4_SteadyState & Base $+1 \mathrm{~m}$ & $15 \mathrm{~cm} / \mathrm{yr}$ & 0.5 & 0.05 & $1.0 \times 10^{-11}$ & 0.3 & 0.0357 & 0 & $9.8 \mathrm{~m} / \mathrm{s}^{2}$ & $0.01 \%$ & $7 \%$ & 36,500 & 86,400 & 1 & \\
\hline 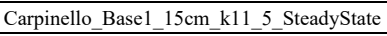 & Base $+1 \mathrm{~m}$ & $15 \mathrm{~cm} / \mathrm{yr}$ & 0.5 & 0.05 & $1.0 \times 10^{-11}$ & 0.3 & 0.0357 & 0 & $9.8 \mathrm{~m} / \mathrm{s}^{2}$ & $0.01 \%$ & $7 \%$ & 36,500 & 86,400 & 1 & \\
\hline $\begin{array}{l}\text { Carpinello_Base1_15cm_k11_6_SteadyState } \\
\end{array}$ & Base $+1 \mathrm{~m}$ & $15 \mathrm{~cm} / \mathrm{yr}$ & 0.5 & 0.05 & $1.0 \times 10^{-11}$ & 0.3 & 0.0357 & 0 & $9.8 \mathrm{~m} / \mathrm{s}^{2}$ & $0.01 \%$ & $7 \%$ & 36,500 & 86,400 & 1 & \\
\hline Carpinello_Base1_15cm_k11_6_Inundation & Base $+1 \mathrm{~m}$ & $15 \mathrm{~cm} / \mathrm{yr}$ & 0.5 & 0.05 & $1.0 \times 10^{-11}$ & 0.3 & 0.0357 & 0 & $9.8 \mathrm{~m} / \mathrm{s}^{2}$ & $0.01 \%$ & $7 \%$ & 147 & 60 & 1.03 & $10 \mathrm{hr}$ \\
\hline Carpinello_Base1_15cm_k11_6_Recovery & Base $+1 \mathrm{~m}$ & $15 \mathrm{~cm} / \mathrm{yr}$ & 0.5 & 0.05 & $1.0 \times 10^{-11}$ & 0.3 & 0.0357 & 0 & $9.8 \mathrm{~m} / \mathrm{s}^{2}$ & $0.01 \%$ & $7 \%$ & 16,000 & 360 & 1.02 & \\
\hline $\begin{array}{l}\text { Carpinello_Base1_20cm_k11_1_SteadyState } \\
\end{array}$ & Base $+1 \mathrm{~m}$ & $20 \mathrm{~cm} / \mathrm{yr}$ & 0.5 & 0.05 & $1.0 \times 10^{-11}$ & 0.3 & 0.0357 & 0 & $9.8 \mathrm{~m} / \mathrm{s}^{2}$ & $0.01 \%$ & $7 \%$ & 36,500 & 86,400 & 1 & \\
\hline Carpinello_Base1_20cm_k11_2_SteadyState & Base $+1 \mathrm{~m}$ & $20 \mathrm{~cm} / \mathrm{yr}$ & 0.5 & 0.05 & $1.0 \times 10^{-11}$ & 0.3 & 0.0357 & 0 & $9.8 \mathrm{~m} / \mathrm{s}^{2}$ & $0.01 \%$ & $7 \%$ & 36,500 & 86,400 & 1 & \\
\hline Carpinello_Base1_20cm_k11_3_SteadyState & Base $+1 \mathrm{~m}$ & $20 \mathrm{~cm} / \mathrm{yr}$ & 0.5 & 0.05 & $1.0 \times 10^{-11}$ & 0.3 & 0.0357 & 0 & $9.8 \mathrm{~m} / \mathrm{s}^{2}$ & $0.01 \%$ & $7 \%$ & 36,500 & 86,400 & 1 & \\
\hline $\begin{array}{l}\text { Carpinello_Base1_20cm_k11_4_SteadyState } \\
\end{array}$ & Base $+1 \mathrm{~m}$ & $20 \mathrm{~cm} / \mathrm{yr}$ & 0.5 & 0.05 & $1.0 \times 10^{-11}$ & 0.3 & 0.0357 & 0 & $9.8 \mathrm{~m} / \mathrm{s}^{2}$ & $0.01 \%$ & $7 \%$ & 36,500 & 86,400 & 1 & \\
\hline $\begin{array}{l}\text { Carpinello_Base1_20cm_k11_5_SteadyState } \\
\end{array}$ & Base $+1 \mathrm{~m}$ & $20 \mathrm{~cm} / \mathrm{yr}$ & 0.5 & 0.05 & $1.0 \times 10^{-11}$ & 0.3 & 0.0357 & 0 & $9.8 \mathrm{~m} / \mathrm{s}^{2}$ & $0.01 \%$ & $7 \%$ & 36,500 & 86,400 & 1 & \\
\hline $\begin{array}{l}\text { Carpinello_Base1_20cm_k11_6_SteadyState } \\
\end{array}$ & Base $+1 \mathrm{~m}$ & $20 \mathrm{~cm} / \mathrm{yr}$ & 0.5 & 0.05 & $1.0 \times 10^{-11}$ & 0.3 & 0.0357 & 0 & $9.8 \mathrm{~m} / \mathrm{s}^{2}$ & $0.01 \%$ & $7 \%$ & 36,500 & 86,400 & 1 & \\
\hline Carpinello_Base1_20cm_k11_6_Inundation & Base $+1 \mathrm{~m}$ & $20 \mathrm{~cm} / \mathrm{yr}$ & 0.5 & 0.05 & $1.0 \times 10^{-11}$ & 0.3 & 0.0357 & 0 & $9.8 \mathrm{~m} / \mathrm{s}^{2}$ & $0.01 \%$ & $7 \%$ & 147 & 60 & 1.03 & $10 \mathrm{hr}$ \\
\hline Carpinello_Base1_20cm_k11_6_Recovery & Base $+1 \mathrm{~m}$ & $20 \mathrm{~cm} / \mathrm{yr}$ & 0.5 & 0.05 & $1.0 \times 10^{-11}$ & 0.3 & 0.0357 & 0 & $9.8 \mathrm{~m} / \mathrm{s}^{2}$ & $0.01 \%$ & $7 \%$ & 16,000 & 360 & 1.02 & \\
\hline $\begin{array}{l}\text { Carpinello_Base1_25cm_k11_1_SteadyState } \\
\end{array}$ & Base $+1 \mathrm{~m}$ & $25 \mathrm{~cm} / \mathrm{yr}$ & 0.5 & 0.05 & $1.0 \times 10^{-11}$ & 0.3 & 0.0357 & 0 & $9.8 \mathrm{~m} / \mathrm{s}^{2}$ & $0.01 \%$ & $7 \%$ & 36,500 & 86,400 & 1 & \\
\hline 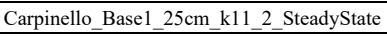 & Base $+1 \mathrm{~m}$ & $25 \mathrm{~cm} / \mathrm{yr}$ & 0.5 & 0.05 & $1.0 \times 10^{-11}$ & 0.3 & 0.0357 & 0 & $9.8 \mathrm{~m} / \mathrm{s}^{2}$ & $0.01 \%$ & $7 \%$ & 36,500 & 86,400 & 1 & \\
\hline 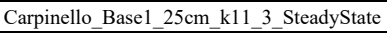 & Base $+1 \mathrm{~m}$ & $25 \mathrm{~cm} / \mathrm{yr}$ & 0.5 & 0.05 & $1.0 \times 10^{-11}$ & 0.3 & 0.0357 & 0 & $9.8 \mathrm{~m} / \mathrm{s}^{2}$ & $0.01 \%$ & $7 \%$ & 36,500 & 86,400 & 1 & \\
\hline Carpinello_Base1_25cm_k11_4_SteadyState & Base $+1 \mathrm{~m}$ & $25 \mathrm{~cm} / \mathrm{yr}$ & 0.5 & 0.05 & $1.0 \times 10^{-11}$ & 0.3 & 0.0357 & 0 & $9.8 \mathrm{~m} / \mathrm{s}^{2}$ & $0.01 \%$ & $7 \%$ & 36,500 & 86,400 & 1 & \\
\hline Carpinello_Base1_25cm_k11_5_SteadyState & Base $+1 \mathrm{~m}$ & $25 \mathrm{~cm} / \mathrm{yr}$ & 0.5 & 0.05 & $1.0 \times 10^{-11}$ & 0.3 & 0.0357 & 0 & $9.8 \mathrm{~m} / \mathrm{s}^{2}$ & $0.01 \%$ & $7 \%$ & 36,500 & 86,400 & 1 & \\
\hline $\begin{array}{l}\text { Carpinello_Base1_25cm_k11_6_SteadyState } \\
\end{array}$ & Base $+1 \mathrm{~m}$ & $25 \mathrm{~cm} / \mathrm{yr}$ & 0.5 & 0.05 & $1.0 \times 10^{-11}$ & 0.3 & 0.0357 & 0 & $9.8 \mathrm{~m} / \mathrm{s}^{2}$ & $0.01 \%$ & $7 \%$ & 36,500 & 86,400 & 1 & \\
\hline Carpinello_Base1_25cm_k11_6_Inundation & Base $+1 \mathrm{~m}$ & $25 \mathrm{~cm} / \mathrm{yr}$ & 0.5 & 0.05 & $1.0 \times 10^{-11}$ & 0.3 & 0.0357 & 0 & $9.8 \mathrm{~m} / \mathrm{s}^{2}$ & $0.01 \%$ & $7 \%$ & 147 & 60 & 1.03 & $10 \mathrm{hr}$ \\
\hline 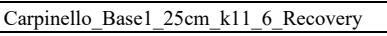 & Base $+1 \mathrm{~m}$ & $25 \mathrm{~cm} / \mathrm{yr}$ & 0.5 & 0.05 & $1.0 \times 10^{-11}$ & 0.3 & 0.0357 & 0 & $9.8 \mathrm{~m} / \mathrm{s}^{2}$ & $0.01 \%$ & $7 \%$ & 16,000 & 360 & 1.02 & \\
\hline
\end{tabular}




\begin{tabular}{|c|c|c|c|c|c|c|c|c|c|c|c|c|c|c|c|}
\hline Model Name & $\begin{array}{c}\text { Unsaturated } \\
\text { Zone } \\
\text { Thickness } \\
\end{array}$ & Recharge & $\begin{array}{c}\text { Longitudinal } \\
\text { Dispersivity } \\
\end{array}$ & $\begin{array}{c}\text { Transverse } \\
\text { Dispersivity }\end{array}$ & Permeability & Porosity & $\begin{array}{c}\text { Seawater } \\
\text { Concentration } \\
\end{array}$ & $\begin{array}{c}\text { Freshwater } \\
\text { Concentration }\end{array}$ & Gravity & $\begin{array}{c}\text { Land } \\
\text { Surface } \\
\text { Slope } \\
\end{array}$ & $\begin{array}{c}\text { Beachface } \\
\text { Slope }\end{array}$ & $\begin{array}{l}\text { Time } \\
\text { Steps } \\
\end{array}$ & $\begin{array}{c}\text { Time } \\
\text { Increment }\end{array}$ & Multiplier & Inundation \\
\hline $\begin{array}{l}\text { Carpinello_Base2_5cm_k11_1_SteadyState } \\
\end{array}$ & Base $+2 \mathrm{~m}$ & $5 \mathrm{~cm} / \mathrm{yr}$ & 0.5 & 0.05 & $1.0 \times 10^{-11}$ & 0.3 & 0.0357 & 0 & $9.8 \mathrm{~m} / \mathrm{s}^{2}$ & $0.01 \%$ & $7 \%$ & 36,500 & 86,400 & 1 & \\
\hline $\begin{array}{l}\text { Carpinello_Base2_5cm_k11_2_SteadyState } \\
\end{array}$ & Base $+2 \mathrm{~m}$ & $5 \mathrm{~cm} / \mathrm{yr}$ & 0.5 & 0.05 & $1.0 \times 10^{-11}$ & 0.3 & 0.0357 & 0 & $9.8 \mathrm{~m} / \mathrm{s}^{2}$ & $0.01 \%$ & $7 \%$ & 36,500 & 86,400 & 1 & \\
\hline $\begin{array}{l}\text { Carpinello_Base2_5cm_k11_3_SteadyState } \\
\end{array}$ & Base $+2 \mathrm{~m}$ & $5 \mathrm{~cm} / \mathrm{yr}$ & 0.5 & 0.05 & $1.0 \times 10^{-11}$ & 0.3 & 0.0357 & 0 & $9.8 \mathrm{~m} / \mathrm{s}^{2}$ & $0.01 \%$ & $7 \%$ & 36,500 & 86,400 & 1 & \\
\hline Carpinello_Base2_5cm_k11_4_SteadyState & Base $+2 \mathrm{~m}$ & $5 \mathrm{~cm} / \mathrm{yr}$ & 0.5 & 0.05 & $1.0 \times 10^{-11}$ & 0.3 & 0.0357 & 0 & $9.8 \mathrm{~m} / \mathrm{s}^{2}$ & $0.01 \%$ & $7 \%$ & 36,500 & 86,400 & 1 & \\
\hline $\begin{array}{l}\text { Carpinello_Base2_5cm_k11_5_SteadyState } \\
\end{array}$ & Base $+2 \mathrm{~m}$ & $5 \mathrm{~cm} / \mathrm{yr}$ & 0.5 & 0.05 & $1.0 \times 10^{-11}$ & 0.3 & 0.0357 & 0 & $9.8 \mathrm{~m} / \mathrm{s}^{2}$ & $0.01 \%$ & $7 \%$ & 36,500 & 86,400 & 1 & \\
\hline $\begin{array}{l}\text { Carpinello_Base2_5cm_k11_6_SteadyState } \\
\end{array}$ & Base $+2 \mathrm{~m}$ & $5 \mathrm{~cm} / \mathrm{yr}$ & 0.5 & 0.05 & $1.0 \times 10^{-11}$ & 0.3 & 0.0357 & 0 & $9.8 \mathrm{~m} / \mathrm{s}^{2}$ & $0.01 \%$ & $7 \%$ & 36,500 & 86,400 & 1 & \\
\hline $\begin{array}{l}\text { Carpinello_Base2_5cm_k11_6_Inundation } \\
\end{array}$ & Base $+2 \mathrm{~m}$ & $5 \mathrm{~cm} / \mathrm{yr}$ & 0.5 & 0.05 & $1.0 \times 10^{-11}$ & 0.3 & 0.0357 & 0 & $9.8 \mathrm{~m} / \mathrm{s}^{2}$ & $0.01 \%$ & $7 \%$ & 147 & 60 & 1.03 & $10 \mathrm{hr}$ \\
\hline Carpinello_Base2_5cm_k11_6_Recovery & Base $+2 \mathrm{~m}$ & $5 \mathrm{~cm} / \mathrm{yr}$ & 0.5 & 0.05 & $1.0 \times 10^{-11}$ & 0.3 & 0.0357 & 0 & $9.8 \mathrm{~m} / \mathrm{s}^{2}$ & $0.01 \%$ & $7 \%$ & 16,000 & 360 & 1.02 & \\
\hline Carpinello_Base2_10cm_k11_1_SteadyState & Base $+2 \mathrm{~m}$ & $10 \mathrm{~cm} / \mathrm{yr}$ & 0.5 & 0.05 & $1.0 \times 10^{-11}$ & 0.3 & 0.0357 & 0 & $9.8 \mathrm{~m} / \mathrm{s}^{2}$ & $0.01 \%$ & $7 \%$ & 36,500 & 86,400 & 1 & \\
\hline 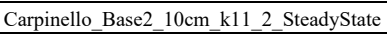 & Base $+2 \mathrm{~m}$ & $10 \mathrm{~cm} / \mathrm{yr}$ & 0.5 & 0.05 & $1.0 \times 10^{-11}$ & 0.3 & 0.0357 & 0 & $9.8 \mathrm{~m} / \mathrm{s}^{2}$ & $0.01 \%$ & $7 \%$ & 36,500 & 86,400 & 1 & \\
\hline 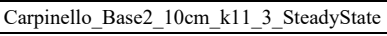 & Base $+2 \mathrm{~m}$ & $10 \mathrm{~cm} / \mathrm{yr}$ & 0.5 & 0.05 & $1.0 \times 10^{-11}$ & 0.3 & 0.0357 & 0 & $9.8 \mathrm{~m} / \mathrm{s}^{2}$ & $0.01 \%$ & $7 \%$ & 36,500 & 86,400 & 1 & \\
\hline Carpinello_Base2_10cm_k11_4_SteadyState & Base $+2 \mathrm{~m}$ & $10 \mathrm{~cm} / \mathrm{yr}$ & 0.5 & 0.05 & $1.0 \times 10^{-11}$ & 0.3 & 0.0357 & 0 & $9.8 \mathrm{~m} / \mathrm{s}^{2}$ & $0.01 \%$ & $7 \%$ & 36,500 & 86,400 & 1 & \\
\hline Carpinello_Base2_10cm_k11_5_SteadyState & Base $+2 \mathrm{~m}$ & $10 \mathrm{~cm} / \mathrm{yr}$ & 0.5 & 0.05 & $1.0 \times 10^{-11}$ & 0.3 & 0.0357 & 0 & $9.8 \mathrm{~m} / \mathrm{s}^{2}$ & $0.01 \%$ & $7 \%$ & 36,500 & 86,400 & 1 & \\
\hline $\begin{array}{l}\text { Carpinello_Base2_10cm_k11_6_SteadyState } \\
\end{array}$ & Base $+2 \mathrm{~m}$ & $10 \mathrm{~cm} / \mathrm{yr}$ & 0.5 & 0.05 & $1.0 \times 10^{-11}$ & 0.3 & 0.0357 & 0 & $9.8 \mathrm{~m} / \mathrm{s}^{2}$ & $0.01 \%$ & $7 \%$ & 36,500 & 86,400 & 1 & \\
\hline $\begin{array}{l}\text { Carpinello_Base2_10cm_k11_6_Inundation } \\
\end{array}$ & Base $+2 \mathrm{~m}$ & $10 \mathrm{~cm} / \mathrm{yr}$ & 0.5 & 0.05 & $1.0 \times 10^{-11}$ & 0.3 & 0.0357 & 0 & $9.8 \mathrm{~m} / \mathrm{s}^{2}$ & $0.01 \%$ & $7 \%$ & 147 & 60 & 1.03 & $10 \mathrm{hr}$ \\
\hline $\begin{array}{l}\text { Carpinello_Base2_10cm_k11_6_Recovery } \\
\end{array}$ & Base $+2 \mathrm{~m}$ & $10 \mathrm{~cm} / \mathrm{yr}$ & 0.5 & 0.05 & $1.0 \times 10^{-11}$ & 0.3 & 0.0357 & 0 & $9.8 \mathrm{~m} / \mathrm{s}^{2}$ & $0.01 \%$ & $7 \%$ & 16,000 & 360 & 1.02 & \\
\hline $\begin{array}{l}\text { Carpinello_Base2_15cm_k11_1_SteadyState } \\
\end{array}$ & Base $+2 \mathrm{~m}$ & $15 \mathrm{~cm} / \mathrm{yr}$ & 0.5 & 0.05 & $1.0 \times 10^{-11}$ & 0.3 & 0.0357 & 0 & $9.8 \mathrm{~m} / \mathrm{s}^{2}$ & $0.01 \%$ & $7 \%$ & 36,500 & 86,400 & 1 & \\
\hline Carpinello_Base2_15cm_k11_2_SteadyState & Base $+2 \mathrm{~m}$ & $15 \mathrm{~cm} / \mathrm{yr}$ & 0.5 & 0.05 & $1.0 \times 10^{-11}$ & 0.3 & 0.0357 & 0 & $9.8 \mathrm{~m} / \mathrm{s}^{2}$ & $0.01 \%$ & $7 \%$ & 36,500 & 86,400 & 1 & \\
\hline $\begin{array}{l}\text { Carpinello_Base2_15cm_k11_3_SteadyState } \\
\end{array}$ & Base $+2 \mathrm{~m}$ & $15 \mathrm{~cm} / \mathrm{yr}$ & 0.5 & 0.05 & $1.0 \times 10^{-11}$ & 0.3 & 0.0357 & 0 & $9.8 \mathrm{~m} / \mathrm{s}^{2}$ & $0.01 \%$ & $7 \%$ & 36,500 & 86,400 & 1 & \\
\hline Carpinello_Base2_15cm_k11_4_SteadyState & Base $+2 \mathrm{~m}$ & $15 \mathrm{~cm} / \mathrm{yr}$ & 0.5 & 0.05 & $1.0 \times 10^{-11}$ & 0.3 & 0.0357 & 0 & $9.8 \mathrm{~m} / \mathrm{s}^{2}$ & $0.01 \%$ & $7 \%$ & 36,500 & 86,400 & 1 & \\
\hline 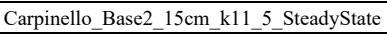 & Base $+2 \mathrm{~m}$ & $15 \mathrm{~cm} / \mathrm{yr}$ & 0.5 & 0.05 & $1.0 \times 10^{-11}$ & 0.3 & 0.0357 & 0 & $9.8 \mathrm{~m} / \mathrm{s}^{2}$ & $0.01 \%$ & $7 \%$ & 36,500 & 86,400 & 1 & \\
\hline $\begin{array}{l}\text { Carpinello_Base2_15cm_k11_6_SteadyState } \\
\end{array}$ & Base $+2 \mathrm{~m}$ & $15 \mathrm{~cm} / \mathrm{yr}$ & 0.5 & 0.05 & $1.0 \times 10^{-11}$ & 0.3 & 0.0357 & 0 & $9.8 \mathrm{~m} / \mathrm{s}^{2}$ & $0.01 \%$ & $7 \%$ & 36,500 & 86,400 & 1 & \\
\hline Carpinello_Base2_15cm_k11_6_Inundation & Base $+2 \mathrm{~m}$ & $15 \mathrm{~cm} / \mathrm{yr}$ & 0.5 & 0.05 & $1.0 \times 10^{-11}$ & 0.3 & 0.0357 & 0 & $9.8 \mathrm{~m} / \mathrm{s}^{2}$ & $0.01 \%$ & $7 \%$ & 147 & 60 & 1.03 & $10 \mathrm{hr}$ \\
\hline Carpinello_Base2_15cm_k11_6_Recovery & Base $+2 \mathrm{~m}$ & $15 \mathrm{~cm} / \mathrm{yr}$ & 0.5 & 0.05 & $1.0 \times 10^{-11}$ & 0.3 & 0.0357 & 0 & $9.8 \mathrm{~m} / \mathrm{s}^{2}$ & $0.01 \%$ & $7 \%$ & 16,000 & 360 & 1.02 & \\
\hline $\begin{array}{l}\text { Carpinello_Base2_20cm_k11_1_SteadyState } \\
\end{array}$ & Base $+2 \mathrm{~m}$ & $20 \mathrm{~cm} / \mathrm{yr}$ & 0.5 & 0.05 & $1.0 \times 10^{-11}$ & 0.3 & 0.0357 & 0 & $9.8 \mathrm{~m} / \mathrm{s}^{2}$ & $0.01 \%$ & $7 \%$ & 36,500 & 86,400 & 1 & \\
\hline Carpinello_Base2_20cm_k11_2_SteadyState & Base $+2 \mathrm{~m}$ & $20 \mathrm{~cm} / \mathrm{yr}$ & 0.5 & 0.05 & $1.0 \times 10^{-11}$ & 0.3 & 0.0357 & 0 & $9.8 \mathrm{~m} / \mathrm{s}^{2}$ & $0.01 \%$ & $7 \%$ & 36,500 & 86,400 & 1 & \\
\hline Carpinello_Base2_20cm_k11_3_SteadyState & Base $+2 \mathrm{~m}$ & $20 \mathrm{~cm} / \mathrm{yr}$ & 0.5 & 0.05 & $1.0 \times 10^{-11}$ & 0.3 & 0.0357 & 0 & $9.8 \mathrm{~m} / \mathrm{s}^{2}$ & $0.01 \%$ & $7 \%$ & 36,500 & 86,400 & 1 & \\
\hline $\begin{array}{l}\text { Carpinello_Base2_20cm_k11_4_SteadyState } \\
\end{array}$ & Base $+2 \mathrm{~m}$ & $20 \mathrm{~cm} / \mathrm{yr}$ & 0.5 & 0.05 & $1.0 \times 10^{-11}$ & 0.3 & 0.0357 & 0 & $9.8 \mathrm{~m} / \mathrm{s}^{2}$ & $0.01 \%$ & $7 \%$ & 36,500 & 86,400 & 1 & \\
\hline 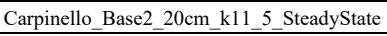 & Base $+2 \mathrm{~m}$ & $20 \mathrm{~cm} / \mathrm{yr}$ & 0.5 & 0.05 & $1.0 \times 10^{-11}$ & 0.3 & 0.0357 & 0 & $9.8 \mathrm{~m} / \mathrm{s}^{2}$ & $0.01 \%$ & $7 \%$ & 36,500 & 86,400 & 1 & \\
\hline $\begin{array}{l}\text { Carpinello_Base2_20cm_k11_6_SteadyState } \\
\end{array}$ & Base $+2 \mathrm{~m}$ & $20 \mathrm{~cm} / \mathrm{yr}$ & 0.5 & 0.05 & $1.0 \times 10^{-11}$ & 0.3 & 0.0357 & 0 & $9.8 \mathrm{~m} / \mathrm{s}^{2}$ & $0.01 \%$ & $7 \%$ & 36,500 & 86,400 & 1 & \\
\hline Carpinello_Base2_20 $\mathrm{cm} \_\mathrm{k} 11 \_6$ Inundation & Base $+2 \mathrm{~m}$ & $20 \mathrm{~cm} / \mathrm{yr}$ & 0.5 & 0.05 & $1.0 \times 10^{-11}$ & 0.3 & 0.0357 & 0 & $9.8 \mathrm{~m} / \mathrm{s}^{2}$ & $0.01 \%$ & $7 \%$ & 147 & 60 & 1.03 & $10 \mathrm{hr}$ \\
\hline Carpinello_Base2_20cm_k11_6_Recovery & Base $+2 \mathrm{~m}$ & $20 \mathrm{~cm} / \mathrm{yr}$ & 0.5 & 0.05 & $1.0 \times 10^{-11}$ & 0.3 & 0.0357 & 0 & $9.8 \mathrm{~m} / \mathrm{s}^{2}$ & $0.01 \%$ & $7 \%$ & 16,000 & 360 & 1.02 & \\
\hline $\begin{array}{l}\text { Carpinello_Base2_25cm_k11_1_SteadyState } \\
\end{array}$ & Base $+2 \mathrm{~m}$ & $25 \mathrm{~cm} / \mathrm{yr}$ & 0.5 & 0.05 & $1.0 \times 10^{-11}$ & 0.3 & 0.0357 & 0 & $9.8 \mathrm{~m} / \mathrm{s}^{2}$ & $0.01 \%$ & $7 \%$ & 36,500 & 86,400 & 1 & \\
\hline 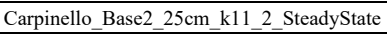 & Base $+2 \mathrm{~m}$ & $25 \mathrm{~cm} / \mathrm{yr}$ & 0.5 & 0.05 & $1.0 \times 10^{-11}$ & 0.3 & 0.0357 & 0 & $9.8 \mathrm{~m} / \mathrm{s}^{2}$ & $0.01 \%$ & $7 \%$ & 36,500 & 86,400 & 1 & \\
\hline 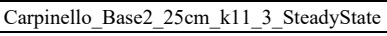 & Base $+2 \mathrm{~m}$ & $25 \mathrm{~cm} / \mathrm{yr}$ & 0.5 & 0.05 & $1.0 \times 10^{-11}$ & 0.3 & 0.0357 & 0 & $9.8 \mathrm{~m} / \mathrm{s}^{2}$ & $0.01 \%$ & $7 \%$ & 36,500 & 86,400 & 1 & \\
\hline Carpinello_Base2_25cm_k11_4_SteadyState & Base $+2 \mathrm{~m}$ & $25 \mathrm{~cm} / \mathrm{yr}$ & 0.5 & 0.05 & $1.0 \times 10^{-11}$ & 0.3 & 0.0357 & 0 & $9.8 \mathrm{~m} / \mathrm{s}^{2}$ & $0.01 \%$ & $7 \%$ & 36,500 & 86,400 & 1 & \\
\hline Carpinello_Base2_25cm_k11_5_SteadyState & Base $+2 \mathrm{~m}$ & $25 \mathrm{~cm} / \mathrm{yr}$ & 0.5 & 0.05 & $1.0 \times 10^{-11}$ & 0.3 & 0.0357 & 0 & $9.8 \mathrm{~m} / \mathrm{s}^{2}$ & $0.01 \%$ & $7 \%$ & 36,500 & 86,400 & 1 & \\
\hline $\begin{array}{l}\text { Carpinello_Base2_25cm_k11_6_SteadyState } \\
\end{array}$ & Base $+2 \mathrm{~m}$ & $25 \mathrm{~cm} / \mathrm{yr}$ & 0.5 & 0.05 & $1.0 \times 10^{-11}$ & 0.3 & 0.0357 & 0 & $9.8 \mathrm{~m} / \mathrm{s}^{2}$ & $0.01 \%$ & $7 \%$ & 36,500 & 86,400 & 1 & \\
\hline Carpinello_Base2_25cm_k11_6_Inundation & Base $+2 \mathrm{~m}$ & $25 \mathrm{~cm} / \mathrm{yr}$ & 0.5 & 0.05 & $1.0 \times 10^{-11}$ & 0.3 & 0.0357 & 0 & $9.8 \mathrm{~m} / \mathrm{s}^{2}$ & $0.01 \%$ & $7 \%$ & 147 & 60 & 1.03 & $10 \mathrm{hr}$ \\
\hline Carpinello_Base2_25cm_k11_6_Recovery & Base $+2 \mathrm{~m}$ & $25 \mathrm{~cm} / \mathrm{yr}$ & 0.5 & 0.05 & $1.0 \times 10^{-11}$ & 0.3 & 0.0357 & 0 & $9.8 \mathrm{~m} / \mathrm{s}^{2}$ & $0.01 \%$ & $7 \%$ & 16,000 & 360 & 1.02 & \\
\hline
\end{tabular}




\begin{tabular}{|c|c|c|c|c|c|c|c|c|c|c|c|c|c|c|c|}
\hline Model Name & $\begin{array}{c}\text { Unsaturated } \\
\text { Zone } \\
\text { Thickness } \\
\end{array}$ & Recharge & $\begin{array}{c}\text { Longitudinal } \\
\text { Dispersivity } \\
\end{array}$ & $\begin{array}{c}\text { Transverse } \\
\text { Dispersivity }\end{array}$ & Permeability & Porosity & $\begin{array}{c}\text { Seawater } \\
\text { Concentration } \\
\end{array}$ & $\begin{array}{c}\text { Freshwater } \\
\text { Concentration }\end{array}$ & Gravity & $\begin{array}{c}\text { Land } \\
\text { Surface } \\
\text { Slope } \\
\end{array}$ & $\begin{array}{c}\text { Beachface } \\
\text { Slope }\end{array}$ & $\begin{array}{l}\text { Time } \\
\text { Steps } \\
\end{array}$ & $\begin{array}{c}\text { Time } \\
\text { Increment }\end{array}$ & Multiplier & Inundatior \\
\hline $\begin{array}{l}\text { Carpinello_Base3_5cm_k11_1_SteadyState } \\
\end{array}$ & Base $+3 \mathrm{~m}$ & $5 \mathrm{~cm} / \mathrm{yr}$ & 0.5 & 0.05 & $1.0 \times 10^{-11}$ & 0.3 & 0.0357 & 0 & $9.8 \mathrm{~m} / \mathrm{s}^{2}$ & $0.01 \%$ & $7 \%$ & 36,500 & 86,400 & 1 & \\
\hline $\begin{array}{l}\text { Carpinello_Base3_5cm_k11_2_SteadyState } \\
\end{array}$ & Base $+3 \mathrm{~m}$ & $5 \mathrm{~cm} / \mathrm{yr}$ & 0.5 & 0.05 & $1.0 \times 10^{-11}$ & 0.3 & 0.0357 & 0 & $9.8 \mathrm{~m} / \mathrm{s}^{2}$ & $0.01 \%$ & $7 \%$ & 36,500 & 86,400 & 1 & \\
\hline Carpinello_Base3_5cm_k11_3_SteadyState & Base $+3 \mathrm{~m}$ & $5 \mathrm{~cm} / \mathrm{yr}$ & 0.5 & 0.05 & $1.0 \times 10^{-11}$ & 0.3 & 0.0357 & 0 & $9.8 \mathrm{~m} / \mathrm{s}^{2}$ & $0.01 \%$ & $7 \%$ & 36,500 & 86,400 & 1 & \\
\hline Carpinello_Base3_5cm_k11_4_SteadyState & Base $+3 \mathrm{~m}$ & $5 \mathrm{~cm} / \mathrm{yr}$ & 0.5 & 0.05 & $1.0 \times 10^{-11}$ & 0.3 & 0.0357 & 0 & $9.8 \mathrm{~m} / \mathrm{s}^{2}$ & $0.01 \%$ & $7 \%$ & 36,500 & 86,400 & 1 & \\
\hline $\begin{array}{l}\text { Carpinello_Base3_5cm_k11_5_SteadyState } \\
\end{array}$ & Base $+3 \mathrm{~m}$ & $5 \mathrm{~cm} / \mathrm{yr}$ & 0.5 & 0.05 & $1.0 \times 10^{-11}$ & 0.3 & 0.0357 & 0 & $9.8 \mathrm{~m} / \mathrm{s}^{2}$ & $0.01 \%$ & $7 \%$ & 36,500 & 86,400 & 1 & \\
\hline Carpinello_Base3_5cm_k11_6_SteadyState & Base $+3 \mathrm{~m}$ & $5 \mathrm{~cm} / \mathrm{yr}$ & 0.5 & 0.05 & $1.0 \times 10^{-11}$ & 0.3 & 0.0357 & 0 & $9.8 \mathrm{~m} / \mathrm{s}^{2}$ & $0.01 \%$ & $7 \%$ & 36,500 & 86,400 & 1 & \\
\hline $\begin{array}{l}\text { Carpinello_Base3_5cm_k11_6_Inundation } \\
\end{array}$ & Base $+3 \mathrm{~m}$ & $5 \mathrm{~cm} / \mathrm{yr}$ & 0.5 & 0.05 & $1.0 \times 10^{-11}$ & 0.3 & 0.0357 & 0 & $9.8 \mathrm{~m} / \mathrm{s}^{2}$ & $0.01 \%$ & $7 \%$ & 147 & 60 & 1.03 & $10 \mathrm{hr}$ \\
\hline Carpinello_Base3_5cm_k11_6_Recovery & Base $+3 \mathrm{~m}$ & $5 \mathrm{~cm} / \mathrm{yr}$ & 0.5 & 0.05 & $1.0 \times 10^{-11}$ & 0.3 & 0.0357 & 0 & $9.8 \mathrm{~m} / \mathrm{s}^{2}$ & $0.01 \%$ & $7 \%$ & 16,000 & 360 & 1.02 & \\
\hline Carpinello_Base3_10cm_k11_1_SteadyState & Base $+3 \mathrm{~m}$ & $10 \mathrm{~cm} / \mathrm{yr}$ & 0.5 & 0.05 & $1.0 \times 10^{-11}$ & 0.3 & 0.0357 & 0 & $9.8 \mathrm{~m} / \mathrm{s}^{2}$ & $0.01 \%$ & $7 \%$ & 36,500 & 86,400 & 1 & \\
\hline 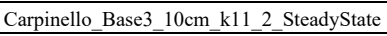 & Base $+3 \mathrm{~m}$ & $10 \mathrm{~cm} / \mathrm{yr}$ & 0.5 & 0.05 & $1.0 \times 10^{-11}$ & 0.3 & 0.0357 & 0 & $9.8 \mathrm{~m} / \mathrm{s}^{2}$ & $0.01 \%$ & $7 \%$ & 36,500 & 86,400 & 1 & \\
\hline 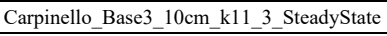 & Base $+3 \mathrm{~m}$ & $10 \mathrm{~cm} / \mathrm{yr}$ & 0.5 & 0.05 & $1.0 \times 10^{-11}$ & 0.3 & 0.0357 & 0 & $9.8 \mathrm{~m} / \mathrm{s}^{2}$ & $0.01 \%$ & $7 \%$ & 36,500 & 86,400 & 1 & \\
\hline Carpinello_Base3_10cm_k11_4_SteadyState & Base $+3 \mathrm{~m}$ & $10 \mathrm{~cm} / \mathrm{yr}$ & 0.5 & 0.05 & $1.0 \times 10^{-11}$ & 0.3 & 0.0357 & 0 & $9.8 \mathrm{~m} / \mathrm{s}^{2}$ & $0.01 \%$ & $7 \%$ & 36,500 & 86,400 & 1 & \\
\hline 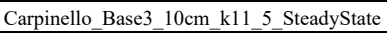 & Base $+3 \mathrm{~m}$ & $10 \mathrm{~cm} / \mathrm{yr}$ & 0.5 & 0.05 & $1.0 \times 10^{-11}$ & 0.3 & 0.0357 & 0 & $9.8 \mathrm{~m} / \mathrm{s}^{2}$ & $0.01 \%$ & $7 \%$ & 36,500 & 86,400 & 1 & \\
\hline $\begin{array}{l}\text { Carpinello_Base3_10cm_k11_6_SteadyState } \\
\end{array}$ & Base $+3 \mathrm{~m}$ & $10 \mathrm{~cm} / \mathrm{yr}$ & 0.5 & 0.05 & $1.0 \times 10^{-11}$ & 0.3 & 0.0357 & 0 & $9.8 \mathrm{~m} / \mathrm{s}^{2}$ & $0.01 \%$ & $7 \%$ & 36,500 & 86,400 & 1 & \\
\hline $\begin{array}{l}\text { Carpinello_Base3_10cm_k11_6_Inundation } \\
\end{array}$ & Base $+3 \mathrm{~m}$ & $10 \mathrm{~cm} / \mathrm{yr}$ & 0.5 & 0.05 & $1.0 \times 10^{-11}$ & 0.3 & 0.0357 & 0 & $9.8 \mathrm{~m} / \mathrm{s}^{2}$ & $0.01 \%$ & $7 \%$ & 147 & 60 & 1.03 & $10 \mathrm{hr}$ \\
\hline $\begin{array}{l}\text { Carpinello_Base3_10cm_k11_6_Recovery } \\
\end{array}$ & Base $+3 \mathrm{~m}$ & $10 \mathrm{~cm} / \mathrm{yr}$ & 0.5 & 0.05 & $1.0 \times 10^{-11}$ & 0.3 & 0.0357 & 0 & $9.8 \mathrm{~m} / \mathrm{s}^{2}$ & $0.01 \%$ & $7 \%$ & 16,000 & 360 & 1.02 & \\
\hline $\begin{array}{l}\text { Carpinello_Base3_15cm_k11_1_SteadyState } \\
\end{array}$ & Base $+3 \mathrm{~m}$ & $15 \mathrm{~cm} / \mathrm{yr}$ & 0.5 & 0.05 & $1.0 \times 10^{-11}$ & 0.3 & 0.0357 & 0 & $9.8 \mathrm{~m} / \mathrm{s}^{2}$ & $0.01 \%$ & $7 \%$ & 36,500 & 86,400 & 1 & \\
\hline Carpinello_Base3_15cm_k11_2_SteadyState & Base $+3 \mathrm{~m}$ & $15 \mathrm{~cm} / \mathrm{yr}$ & 0.5 & 0.05 & $1.0 \times 10^{-11}$ & 0.3 & 0.0357 & 0 & $9.8 \mathrm{~m} / \mathrm{s}^{2}$ & $0.01 \%$ & $7 \%$ & 36,500 & 86,400 & 1 & \\
\hline $\begin{array}{l}\text { Carpinello_Base3_15cm_k11_3_SteadyState } \\
\end{array}$ & Base $+3 \mathrm{~m}$ & $15 \mathrm{~cm} / \mathrm{yr}$ & 0.5 & 0.05 & $1.0 \times 10^{-11}$ & 0.3 & 0.0357 & 0 & $9.8 \mathrm{~m} / \mathrm{s}^{2}$ & $0.01 \%$ & $7 \%$ & 36,500 & 86,400 & 1 & \\
\hline Carpinello_Base3_15cm_k11_4_SteadyState & Base $+3 \mathrm{~m}$ & $15 \mathrm{~cm} / \mathrm{yr}$ & 0.5 & 0.05 & $1.0 \times 10^{-11}$ & 0.3 & 0.0357 & 0 & $9.8 \mathrm{~m} / \mathrm{s}^{2}$ & $0.01 \%$ & $7 \%$ & 36,500 & 86,400 & 1 & \\
\hline 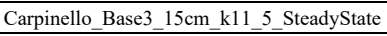 & Base $+3 \mathrm{~m}$ & $15 \mathrm{~cm} / \mathrm{yr}$ & 0.5 & 0.05 & $1.0 \times 10^{-11}$ & 0.3 & 0.0357 & 0 & $9.8 \mathrm{~m} / \mathrm{s}^{2}$ & $0.01 \%$ & $7 \%$ & 36,500 & 86,400 & 1 & \\
\hline $\begin{array}{l}\text { Carpinello_Base3_15cm_k11_6_SteadyState } \\
\end{array}$ & Base $+3 \mathrm{~m}$ & $15 \mathrm{~cm} / \mathrm{yr}$ & 0.5 & 0.05 & $1.0 \times 10^{-11}$ & 0.3 & 0.0357 & 0 & $9.8 \mathrm{~m} / \mathrm{s}^{2}$ & $0.01 \%$ & $7 \%$ & 36,500 & 86,400 & 1 & \\
\hline Carpinello_Base3_15cm_k11_6_Inundation & Base $+3 \mathrm{~m}$ & $15 \mathrm{~cm} / \mathrm{yr}$ & 0.5 & 0.05 & $1.0 \times 10^{-11}$ & 0.3 & 0.0357 & 0 & $9.8 \mathrm{~m} / \mathrm{s}^{2}$ & $0.01 \%$ & $7 \%$ & 147 & 60 & 1.03 & $10 \mathrm{hr}$ \\
\hline Carpinello_Base3_15cm_k11_6_Recovery & Base $+3 \mathrm{~m}$ & $15 \mathrm{~cm} / \mathrm{yr}$ & 0.5 & 0.05 & $1.0 \times 10^{-11}$ & 0.3 & 0.0357 & 0 & $9.8 \mathrm{~m} / \mathrm{s}^{2}$ & $0.01 \%$ & $7 \%$ & 16,000 & 360 & 1.02 & \\
\hline Carpinello_Base3_20cm_k11_1_SteadyState & Base $+3 \mathrm{~m}$ & $20 \mathrm{~cm} / \mathrm{yr}$ & 0.5 & 0.05 & $1.0 \times 10^{-11}$ & 0.3 & 0.0357 & 0 & $9.8 \mathrm{~m} / \mathrm{s}^{2}$ & $0.01 \%$ & $7 \%$ & 36,500 & 86,400 & 1 & \\
\hline Carpinello_Base3_20cm_k11_2_SteadyState & Base $+3 \mathrm{~m}$ & $20 \mathrm{~cm} / \mathrm{yr}$ & 0.5 & 0.05 & $1.0 \times 10^{-11}$ & 0.3 & 0.0357 & 0 & $9.8 \mathrm{~m} / \mathrm{s}^{2}$ & $0.01 \%$ & $7 \%$ & 36,500 & 86,400 & 1 & \\
\hline Carpinello_Base3_20cm_k11_3_SteadyState & Base $+3 \mathrm{~m}$ & $20 \mathrm{~cm} / \mathrm{yr}$ & 0.5 & 0.05 & $1.0 \times 10^{-11}$ & 0.3 & 0.0357 & 0 & $9.8 \mathrm{~m} / \mathrm{s}^{2}$ & $0.01 \%$ & $7 \%$ & 36,500 & 86,400 & 1 & \\
\hline $\begin{array}{l}\text { Carpinello_Base3_20cm_k11_4_SteadyState } \\
\end{array}$ & Base $+3 \mathrm{~m}$ & $20 \mathrm{~cm} / \mathrm{yr}$ & 0.5 & 0.05 & $1.0 \times 10^{-11}$ & 0.3 & 0.0357 & 0 & $9.8 \mathrm{~m} / \mathrm{s}^{2}$ & $0.01 \%$ & $7 \%$ & 36,500 & 86,400 & 1 & \\
\hline 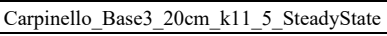 & Base $+3 \mathrm{~m}$ & $20 \mathrm{~cm} / \mathrm{yr}$ & 0.5 & 0.05 & $1.0 \times 10^{-11}$ & 0.3 & 0.0357 & 0 & $9.8 \mathrm{~m} / \mathrm{s}^{2}$ & $0.01 \%$ & $7 \%$ & 36,500 & 86,400 & 1 & \\
\hline $\begin{array}{l}\text { Carpinello_Base3_20cm_k11_6_SteadyState } \\
\end{array}$ & Base $+3 \mathrm{~m}$ & $20 \mathrm{~cm} / \mathrm{yr}$ & 0.5 & 0.05 & $1.0 \times 10^{-11}$ & 0.3 & 0.0357 & 0 & $9.8 \mathrm{~m} / \mathrm{s}^{2}$ & $0.01 \%$ & $7 \%$ & 36,500 & 86,400 & 1 & \\
\hline Carpinello_Base3_20 $\mathrm{cm} \_\mathrm{k} 11 \_6$ Inundation & Base $+3 \mathrm{~m}$ & $20 \mathrm{~cm} / \mathrm{yr}$ & 0.5 & 0.05 & $1.0 \times 10^{-11}$ & 0.3 & 0.0357 & 0 & $9.8 \mathrm{~m} / \mathrm{s}^{2}$ & $0.01 \%$ & $7 \%$ & 147 & 60 & 1.03 & $10 \mathrm{hr}$ \\
\hline Carpinello_Base3_20cm_k11_6_Recovery & Base $+3 \mathrm{~m}$ & $20 \mathrm{~cm} / \mathrm{yr}$ & 0.5 & 0.05 & $1.0 \times 10^{-11}$ & 0.3 & 0.0357 & 0 & $9.8 \mathrm{~m} / \mathrm{s}^{2}$ & $0.01 \%$ & $7 \%$ & 16,000 & 360 & 1.02 & \\
\hline $\begin{array}{l}\text { Carpinello_Base3_25cm_k11_1_SteadyState } \\
\end{array}$ & Base $+3 \mathrm{~m}$ & $25 \mathrm{~cm} / \mathrm{yr}$ & 0.5 & 0.05 & $1.0 \times 10^{-11}$ & 0.3 & 0.0357 & 0 & $9.8 \mathrm{~m} / \mathrm{s}^{2}$ & $0.01 \%$ & $7 \%$ & 36,500 & 86,400 & 1 & \\
\hline 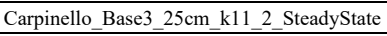 & Base $+3 \mathrm{~m}$ & $25 \mathrm{~cm} / \mathrm{yr}$ & 0.5 & 0.05 & $1.0 \times 10^{-11}$ & 0.3 & 0.0357 & 0 & $9.8 \mathrm{~m} / \mathrm{s}^{2}$ & $0.01 \%$ & $7 \%$ & 36,500 & 86,400 & 1 & \\
\hline 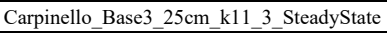 & Base $+3 \mathrm{~m}$ & $25 \mathrm{~cm} / \mathrm{yr}$ & 0.5 & 0.05 & $1.0 \times 10^{-11}$ & 0.3 & 0.0357 & 0 & $9.8 \mathrm{~m} / \mathrm{s}^{2}$ & $0.01 \%$ & $7 \%$ & 36,500 & 86,400 & 1 & \\
\hline Carpinello_Base3_25cm_k11_4_SteadyState & Base $+3 \mathrm{~m}$ & $25 \mathrm{~cm} / \mathrm{yr}$ & 0.5 & 0.05 & $1.0 \times 10^{-11}$ & 0.3 & 0.0357 & 0 & $9.8 \mathrm{~m} / \mathrm{s}^{2}$ & $0.01 \%$ & $7 \%$ & 36,500 & 86,400 & 1 & \\
\hline Carpinello_Base3_25cm_k11_5_SteadyState & Base $+3 \mathrm{~m}$ & $25 \mathrm{~cm} / \mathrm{yr}$ & 0.5 & 0.05 & $1.0 \times 10^{-11}$ & 0.3 & 0.0357 & 0 & $9.8 \mathrm{~m} / \mathrm{s}^{2}$ & $0.01 \%$ & $7 \%$ & 36,500 & 86,400 & 1 & \\
\hline $\begin{array}{l}\text { Carpinello_Base3_25cm_k11_6_SteadyState } \\
\end{array}$ & Base $+3 \mathrm{~m}$ & $25 \mathrm{~cm} / \mathrm{yr}$ & 0.5 & 0.05 & $1.0 \times 10^{-11}$ & 0.3 & 0.0357 & 0 & $9.8 \mathrm{~m} / \mathrm{s}^{2}$ & $0.01 \%$ & $7 \%$ & 36,500 & 86,400 & 1 & \\
\hline Carpinello_Base3_25cm_k11_6_Inundation & Base $+3 \mathrm{~m}$ & $25 \mathrm{~cm} / \mathrm{yr}$ & 0.5 & 0.05 & $1.0 \times 10^{-11}$ & 0.3 & 0.0357 & 0 & $9.8 \mathrm{~m} / \mathrm{s}^{2}$ & $0.01 \%$ & $7 \%$ & 147 & 60 & 1.03 & $10 \mathrm{hr}$ \\
\hline 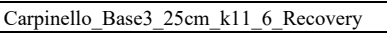 & Base $+3 \mathrm{~m}$ & $25 \mathrm{~cm} / \mathrm{yr}$ & 0.5 & 0.05 & $1.0 \times 10^{-11}$ & 0.3 & 0.0357 & 0 & $9.8 \mathrm{~m} / \mathrm{s}^{2}$ & $0.01 \%$ & $7 \%$ & 16,000 & 360 & 1.02 & \\
\hline
\end{tabular}




\begin{tabular}{|c|c|c|c|c|c|c|c|c|c|c|c|c|c|c|c|}
\hline Model Name & $\begin{array}{c}\text { Unsaturated } \\
\text { Zone } \\
\text { Thickness } \\
\end{array}$ & Recharge & $\begin{array}{c}\text { Longitudinal } \\
\text { Dispersivity }\end{array}$ & $\begin{array}{c}\text { Transverse } \\
\text { Dispersivity }\end{array}$ & Permeability & Porosity & $\begin{array}{c}\text { Seawater } \\
\text { Concentration }\end{array}$ & $\begin{array}{c}\text { Freshwater } \\
\text { Concentration }\end{array}$ & Gravity & $\begin{array}{c}\text { Land } \\
\text { Surface } \\
\text { Slope } \\
\end{array}$ & $\begin{array}{l}\text { Beachface } \\
\text { Slope }\end{array}$ & $\begin{array}{l}\text { Time } \\
\text { Steps }\end{array}$ & $\begin{array}{c}\text { Time } \\
\text { Increment }\end{array}$ & Multiplier & Inundation \\
\hline Carpinello_Base_InunTime_15 $\mathrm{cm} \_\mathrm{k} 11 \_1$ SSteadyState & base & $15 \mathrm{~cm} / \mathrm{yr}$ & 0.5 & 0.05 & $1.0 \times 10^{-11}$ & 0.3 & 0.0357 & 0 & $9.8 \mathrm{~m} / \mathrm{s}^{2}$ & $0.01 \%$ & $7 \%$ & 36,500 & 259,200 & 1 & \\
\hline Carpinello_Base_InunTime_15 $\mathrm{cm} \_\mathrm{k} 11 \_2$ SteadyState & base & $15 \mathrm{~cm} / \mathrm{yr}$ & 0.5 & 0.05 & $1.0 \times 10^{-11}$ & 0.3 & 0.0357 & 0 & $9.8 \mathrm{~m} / \mathrm{s}^{2}$ & $0.01 \%$ & $7 \%$ & 36,500 & 259,200 & 1 & \\
\hline Carpinello_Base_InunTime_15cm_k11_0.5hr_Inundation & base & $15 \mathrm{~cm} / \mathrm{yr}$ & 0.5 & 0.05 & $1.0 \times 10^{-11}$ & 0.3 & 0.0357 & 0 & $9.8 \mathrm{~m} / \mathrm{s}^{2}$ & $0.01 \%$ & $7 \%$ & 21 & 60 & 1.03 & $0.5 \mathrm{hr}$ \\
\hline Carpinello_Base_InunTime_15cm_k11_0.5hr_Recovery & base & $15 \mathrm{~cm} / \mathrm{yr}$ & 0.5 & 0.05 & $1.0 \times 10^{-11}$ & 0.3 & 0.0357 & 0 & $9.8 \mathrm{~m} / \mathrm{s}^{2}$ & $0.01 \%$ & $7 \%$ & 16,000 & 360 & 1.02 & \\
\hline Carpinello_Base_InunTime_15cm_k11_1hr_Inundation & base & $15 \mathrm{~cm} / \mathrm{yr}$ & 0.5 & 0.05 & $1.0 \times 10^{-11}$ & 0.3 & 0.0357 & 0 & $9.8 \mathrm{~m} / \mathrm{s}^{2}$ & $0.01 \%$ & $7 \%$ & 34 & 60 & 1.03 & $1 \mathrm{hr}$ \\
\hline Carpinello_Base_InunTime_15cm_k11_1hr_Recovery & base & $15 \mathrm{~cm} / \mathrm{yr}$ & 0.5 & 0.05 & $1.0 \times 10^{-11}$ & 0.3 & 0.0357 & 0 & $9.8 \mathrm{~m} / \mathrm{s}^{2}$ & $0.01 \%$ & $7 \%$ & 16,000 & 360 & 1.02 & \\
\hline $\begin{array}{l}\text { Carpinello_Base_InunTime_15cm_k11_5hr_Inundation } \\
\end{array}$ & base & $15 \mathrm{~cm} / \mathrm{yr}$ & 0.5 & 0.05 & $1.0 \times 10^{-11}$ & 0.3 & 0.0357 & 0 & $9.8 \mathrm{~m} / \mathrm{s}^{2}$ & $0.01 \%$ & $7 \%$ & 87 & 60 & 1.03 & $5 \mathrm{hr}$ \\
\hline Carpinello_Base_InunTime_15cm_k11_5hr_Recovery & base & $15 \mathrm{~cm} / \mathrm{yr}$ & 0.5 & 0.05 & $1.0 \times 10^{-11}$ & 0.3 & 0.0357 & 0 & $9.8 \mathrm{~m} / \mathrm{s}^{2}$ & $0.01 \%$ & $7 \%$ & 16,000 & 360 & 1.02 & \\
\hline Carpinello_Base_15cm_k11_Inundation & base & $15 \mathrm{~cm} / \mathrm{yr}$ & 0.5 & 0.05 & $1.0 \times 10^{-11}$ & 0.3 & 0.0357 & 0 & $9.8 \mathrm{~m} / \mathrm{s}^{2}$ & $0.01 \%$ & $7 \%$ & 147 & 60 & 1.03 & $10 \mathrm{hr}$ \\
\hline Carpinello_Base $15 \mathrm{~cm}$ k $\mathrm{k} 11$ Recovery & base & $15 \mathrm{~cm} / \mathrm{yr}$ & 0.5 & 0.05 & $1.0 \times 10^{-11}$ & 0.3 & 0.0357 & 0 & $9.8 \mathrm{~m} / \mathrm{s}^{2}$ & $0.01 \%$ & $7 \%$ & 16,000 & 360 & 1.02 & \\
\hline Carpinello_Base_InunTime_15cm_k11_20hr_Inundation & base & $15 \mathrm{~cm} / \mathrm{yr}$ & 0.5 & 0.05 & $1.0 \times 10^{-11}$ & 0.3 & 0.0357 & 0 & $9.8 \mathrm{~m} / \mathrm{s}^{2}$ & $0.01 \%$ & $7 \%$ & 267 & 60 & 1.03 & $20 \mathrm{hr}$ \\
\hline 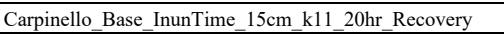 & base & $15 \mathrm{~cm} / \mathrm{yr}$ & 0.5 & 0.05 & $1.0 \times 10^{-11}$ & 0.3 & 0.0357 & 0 & $9.8 \mathrm{~m} / \mathrm{s}^{2}$ & $0.01 \%$ & $7 \%$ & 16,000 & 360 & 1.02 & \\
\hline Carpinello_Base_InunTime_15 & base & $15 \mathrm{~cm} / \mathrm{yr}$ & 0.5 & 0.05 & $1.0 \times 10^{-11}$ & 0.3 & 0.0357 & 0 & $9.8 \mathrm{~m} / \mathrm{s}^{2}$ & $0.01 \%$ & $7 \%$ & 627 & 60 & 1.03 & $50 \mathrm{hr}$ \\
\hline Carpinello_Base_InunTime_15cm_k11_50hr_Recovery & base & $15 \mathrm{~cm} / \mathrm{yr}$ & 0.5 & 0.05 & $1.0 \times 10^{-11}$ & 0.3 & 0.0357 & 0 & $9.8 \mathrm{~m} / \mathrm{s}^{2}$ & $0.01 \%$ & $7 \%$ & 16,000 & 360 & 1.02 & \\
\hline $\begin{array}{l}\text { Carpinello_Base_InunTime_15cm_k11_100hr_Inundation } \\
\end{array}$ & base & $15 \mathrm{~cm} / \mathrm{yr}$ & 0.5 & 0.05 & $1.0 \times 10^{-11}$ & 0.3 & 0.0357 & 0 & $9.8 \mathrm{~m} / \mathrm{s}^{2}$ & $0.01 \%$ & $7 \%$ & 1,227 & 60 & 1.03 & $\mathrm{hr}$ \\
\hline Carpinello_Base_InunTime_15cm_k11_100hr_Recovery & base & $15 \mathrm{~cm} / \mathrm{yr}$ & 0.5 & 0.05 & $1.0 \times 10^{-11}$ & 0.3 & 0.0357 & 0 & $9.8 \mathrm{~m} / \mathrm{s}^{2}$ & $0.01 \%$ & $7 \%$ & 16,000 & 360 & 1.02 & \\
\hline
\end{tabular}

\begin{tabular}{|c|c|c|c|c|c|c|c|c|c|c|c|c|c|c|c|}
\hline Model Name & $\begin{array}{c}\text { Unsaturated } \\
\text { Zone } \\
\text { Thickness } \\
\end{array}$ & Recharge & $\begin{array}{c}\text { Longitudinal } \\
\text { Dispersivity }\end{array}$ & $\begin{array}{c}\text { Transverse } \\
\text { Dispersivity }\end{array}$ & Permeability & Porosity & $\begin{array}{c}\text { Seawater } \\
\text { Concentration }\end{array}$ & $\begin{array}{c}\text { Freshwater } \\
\text { Concentration }\end{array}$ & Gravity & $\begin{array}{c}\text { Land } \\
\text { Surface } \\
\text { Slope } \\
\end{array}$ & $\begin{array}{c}\text { Beachface } \\
\text { Slope }\end{array}$ & $\begin{array}{l}\text { Time } \\
\text { Steps }\end{array}$ & $\begin{array}{c}\text { Time } \\
\text { Increment }\end{array}$ & Multiplier & Inundation \\
\hline $\begin{array}{l}\text { Carpinello_Base2_InunTime_15cm_k11_1_SteadyState } \\
\end{array}$ & Base $+2 \mathrm{~m}$ & $15 \mathrm{~cm} / \mathrm{yr}$ & 0.5 & 0.05 & $1.0 \times 10^{-11}$ & 0.3 & 0.0357 & 0 & $9.8 \mathrm{~m} / \mathrm{s}^{2}$ & $0.01 \%$ & $7 \%$ & 36,500 & 86,400 & 1 & \\
\hline $\begin{array}{l}\text { Carpinello_Base2_InunTime_15cm_k11_2_SteadyState } \\
\end{array}$ & Base $+2 \mathrm{~m}$ & $15 \mathrm{~cm} / \mathrm{yr}$ & 0.5 & 0.05 & $1.0 \times 10^{-11}$ & 0.3 & 0.0357 & 0 & $9.8 \mathrm{~m} / \mathrm{s}^{2}$ & $0.01 \%$ & $7 \%$ & 36,500 & 86,400 & 1 & \\
\hline $\begin{array}{l}\text { Carpinello_Base2_InunTime_15cm_k11_3_SteadyState } \\
\end{array}$ & Base $+2 \mathrm{~m}$ & $15 \mathrm{~cm} / \mathrm{yr}$ & 0.5 & 0.05 & $1.0 \times 10^{-11}$ & 0.3 & 0.0357 & 0 & $9.8 \mathrm{~m} / \mathrm{s}^{2}$ & $0.01 \%$ & $7 \%$ & 36,500 & 86,400 & 1 & \\
\hline $\begin{array}{l}\text { Carpinello_Base2_InunTime_15cm_k11_4_SteadyState } \\
\end{array}$ & Base $+2 \mathrm{~m}$ & $15 \mathrm{~cm} / \mathrm{yr}$ & 0.5 & 0.05 & $1.0 \times 10^{-11}$ & 0.3 & 0.0357 & 0 & $9.8 \mathrm{~m} / \mathrm{s}^{2}$ & $0.01 \%$ & $7 \%$ & 36,500 & 86,400 & 1 & \\
\hline Carpinello_Base2_InunTime_15cm_k11_5_SteadyState & Base $+2 \mathrm{~m}$ & $15 \mathrm{~cm} / \mathrm{yr}$ & 0.5 & 0.05 & $1.0 \times 10^{-11}$ & 0.3 & 0.0357 & 0 & $9.8 \mathrm{~m} / \mathrm{s}^{2}$ & $0.01 \%$ & $7 \%$ & 36,500 & 86,400 & 1 & \\
\hline $\begin{array}{l}\text { Carpinello_Base2_InunTime_15cm_k11_6_SteadyState } \\
\end{array}$ & Base $+2 \mathrm{~m}$ & $15 \mathrm{~cm} / \mathrm{yr}$ & 0.5 & 0.05 & $1.0 \times 10^{-11}$ & 0.3 & 0.0357 & 0 & $9.8 \mathrm{~m} / \mathrm{s}^{2}$ & $0.01 \%$ & $7 \%$ & 36,500 & 86,400 & 1 & \\
\hline Carpinello_Base2_InunTime_15cm_k11_0.5hr_Inundation & Base $+2 \mathrm{~m}$ & $15 \mathrm{~cm} / \mathrm{yr}$ & 0.5 & 0.05 & $1.0 \times 10^{-11}$ & 0.3 & 0.0357 & 0 & $9.8 \mathrm{~m} / \mathrm{s}^{2}$ & $0.01 \%$ & $7 \%$ & 21 & 60 & 1.03 & $0.5 \mathrm{hr}$ \\
\hline Carpinello_Base2_InunTime_15cm_k11_0.5hr_Recovery & Base $+2 \mathrm{~m}$ & $15 \mathrm{~cm} / \mathrm{yr}$ & 0.5 & 0.05 & $1.0 \times 10^{-11}$ & 0.3 & 0.0357 & 0 & $9.8 \mathrm{~m} / \mathrm{s}^{2}$ & $0.01 \%$ & $7 \%$ & 16,000 & 360 & 1.02 & \\
\hline Carpinello_Base2_InunTime_15cm_k11_lhr_Inundation & Base $+2 \mathrm{~m}$ & $15 \mathrm{~cm} / \mathrm{yr}$ & 0.5 & 0.05 & $1.0 \times 10^{-11}$ & 0.3 & 0.0357 & 0 & $9.8 \mathrm{~m} / \mathrm{s}^{2}$ & $0.01 \%$ & $7 \%$ & 34 & 60 & 1.03 & $1 \mathrm{hr}$ \\
\hline Carpinello_Base2_InunTime_15cm_k11_1 $1 \mathrm{hr}$ Recovery & Base $+2 \mathrm{~m}$ & $15 \mathrm{~cm} / \mathrm{yr}$ & 0.5 & 0.05 & $1.0 \times 10^{-11}$ & 0.3 & 0.0357 & 0 & $9.8 \mathrm{~m} / \mathrm{s}^{2}$ & $0.01 \%$ & $7 \%$ & 16,000 & 360 & 1.02 & \\
\hline Carpinello_Base2_InunTime_15cm_k11_5hr_Inundation & Base $+2 \mathrm{~m}$ & $15 \mathrm{~cm} / \mathrm{yr}$ & 0.5 & 0.05 & $1.0 \times 10^{-11}$ & 0.3 & 0.0357 & 0 & $9.8 \mathrm{~m} / \mathrm{s}^{2}$ & $0.01 \%$ & $7 \%$ & 87 & 60 & 1.03 & $5 \mathrm{hr}$ \\
\hline $\begin{array}{l}\text { Carpinello_Base2_InunTime_15cm_k11_5hr_Recovery } \\
\end{array}$ & Base $+2 \mathrm{~m}$ & $15 \mathrm{~cm} / \mathrm{yr}$ & 0.5 & 0.05 & $1.0 \times 10^{-11}$ & 0.3 & 0.0357 & 0 & $9.8 \mathrm{~m} / \mathrm{s}^{2}$ & $0.01 \%$ & $7 \%$ & 16,000 & 360 & 1.02 & \\
\hline Carpinello_Base2_15cm_k11_6_Inundation & Base $+2 \mathrm{~m}$ & $15 \mathrm{~cm} / \mathrm{yr}$ & 0.5 & 0.05 & $1.0 \times 10^{-11}$ & 0.3 & 0.0357 & 0 & $9.8 \mathrm{~m} / \mathrm{s}^{2}$ & $0.01 \%$ & $7 \%$ & 147 & 60 & 1.03 & $10 \mathrm{hr}$ \\
\hline Carpinello_Base2_15cm_k11_6_Recovery & Base $+2 \mathrm{~m}$ & $15 \mathrm{~cm} / \mathrm{yr}$ & 0.5 & 0.05 & $1.0 \times 10^{-11}$ & 0.3 & 0.0357 & 0 & $9.8 \mathrm{~m} / \mathrm{s}^{2}$ & $0.01 \%$ & $7 \%$ & 16,000 & 360 & 1.02 & \\
\hline $\begin{array}{l}\text { Carpinello_Base2_InunTime_15cm_k11_20hr_Inundation } \\
\end{array}$ & Base $+2 \mathrm{~m}$ & $15 \mathrm{~cm} / \mathrm{yr}$ & 0.5 & 0.05 & $1.0 \times 10^{-11}$ & 0.3 & 0.0357 & 0 & $9.8 \mathrm{~m} / \mathrm{s}^{2}$ & $0.01 \%$ & $7 \%$ & 267 & 60 & 1.03 & $20 \mathrm{hr}$ \\
\hline Carpinello_Base2_InunTime_15cm_k11_20hr_Recovery & Base $+2 \mathrm{~m}$ & $15 \mathrm{~cm} / \mathrm{yr}$ & 0.5 & 0.05 & $1.0 \times 10^{-11}$ & 0.3 & 0.0357 & 0 & $9.8 \mathrm{~m} / \mathrm{s}^{2}$ & $0.01 \%$ & $7 \%$ & 16,000 & 360 & 1.02 & \\
\hline $\begin{array}{l}\text { Carpinello_Base2_InunTime_15cm_k11_50hr_Inundation } \\
\end{array}$ & Base $+2 \mathrm{~m}$ & $15 \mathrm{~cm} / \mathrm{yr}$ & 0.5 & 0.05 & $1.0 \times 10^{-11}$ & 0.3 & 0.0357 & 0 & $9.8 \mathrm{~m} / \mathrm{s}^{2}$ & $0.01 \%$ & $7 \%$ & 627 & 60 & 1.03 & $50 \mathrm{hr}$ \\
\hline Carpinello_Base2_InunTime_15cm_k11_50hr_Recovery & Base $+2 \mathrm{~m}$ & $15 \mathrm{~cm} / \mathrm{yr}$ & 0.5 & 0.05 & $1.0 \times 10^{-11}$ & 0.3 & 0.0357 & 0 & $9.8 \mathrm{~m} / \mathrm{s}^{2}$ & $0.01 \%$ & $7 \%$ & 16,000 & 360 & 1.02 & \\
\hline Carpinello_Base2_InunTime_15cm_k11_100hr_Inundation & Base $+2 \mathrm{~m}$ & $15 \mathrm{~cm} / \mathrm{yr}$ & 0.5 & 0.05 & $1.0 \times 10^{-11}$ & 0.3 & 0.0357 & 0 & $9.8 \mathrm{~m} / \mathrm{s}^{2}$ & $0.01 \%$ & $7 \%$ & 1,227 & 60 & 1.03 & $\mathrm{hr}$ \\
\hline $\begin{array}{l}\text { Carpinello_Base2_InunTime_15cm_k11_100hr_Recovery } \\
\end{array}$ & Base $+2 \mathrm{~m}$ & $15 \mathrm{~cm} / \mathrm{yr}$ & 0.5 & 0.05 & $1.0 \times 10^{-11}$ & 0.3 & 0.0357 & 0 & $9.8 \mathrm{~m} / \mathrm{s}^{2}$ & $0.01 \%$ & $7 \%$ & 16,000 & 360 & 1.02 & \\
\hline
\end{tabular}

Table 6: Base Model + 2 m Inundation Time Simulations 


\begin{tabular}{|c|c|c|c|c|c|c|c|c|c|c|c|c|c|c|c|}
\hline Model Name & $\begin{array}{c}\text { Unsaturated } \\
\text { Zone } \\
\text { Thickness } \\
\end{array}$ & Recharge & $\begin{array}{c}\text { Longitudinal } \\
\text { Dispersivity } \\
\end{array}$ & $\begin{array}{c}\text { Transverse } \\
\text { Dispersivity } \\
\end{array}$ & Permeability & Porosity & $\begin{array}{c}\text { Seawater } \\
\text { Concentration }\end{array}$ & $\begin{array}{c}\text { Freshwater } \\
\text { Concentration }\end{array}$ & Gravity & $\begin{array}{c}\text { Land } \\
\text { Surface } \\
\text { Slope } \\
\end{array}$ & $\begin{array}{c}\text { Beachface } \\
\text { Slope }\end{array}$ & $\begin{array}{l}\text { Time } \\
\text { Steps }\end{array}$ & $\begin{array}{c}\text { Time } \\
\text { Increment }\end{array}$ & Multiplier & Inundation \\
\hline Carpinello_Base_5cm_k11_1_SteadyState & base & $15 \mathrm{~cm} / \mathrm{yr}$ & 0.5 & 0.05 & $1.0 \times 10^{-11}$ & 0.3 & 0.0357 & 0 & $9.8 \mathrm{~m} / \mathrm{s}^{2}$ & $0.01 \%$ & $7 \%$ & 36,500 & 259,200 & 1 & \\
\hline Carpinello_Base_5 $5 \mathrm{~cm} \_\mathrm{k} 11 \_2$ SteadyState & base & $15 \mathrm{~cm} / \mathrm{yr}$ & 0.5 & 0.05 & $1.0 \times 10^{-11}$ & 0.3 & 0.0357 & 0 & $9.8 \mathrm{~m} / \mathrm{s}^{2}$ & $0.01 \%$ & $7 \%$ & 36,500 & 259,200 & 1 & \\
\hline Carpinello_Base_5cm_k11_2_Inundation & base & $15 \mathrm{~cm} / \mathrm{yr}$ & 0.5 & 0.05 & $1.0 \times 10^{-11}$ & 0.3 & 0.0357 & 0 & $9.8 \mathrm{~m} / \mathrm{s}^{2}$ & $0.01 \%$ & $7 \%$ & 147 & 60 & 1.03 & $10 \mathrm{hr}$ \\
\hline Carpinello_Base $5 \mathrm{~cm} \_\mathrm{k} 11 \_2$ Recovery & base & $15 \mathrm{~cm} / \mathrm{yr}$ & 0.5 & 0.05 & $1.0 \times 10^{-11}$ & 0.3 & 0.0357 & 0 & $9.8 \mathrm{~m} / \mathrm{s}^{2}$ & $0.01 \%$ & $7 \%$ & 16,000 & 360 & 1.02 & \\
\hline Carpinello_Base_5cm_k5512_1_SteadyState & base & $15 \mathrm{~cm} / \mathrm{yr}$ & 0.5 & 0.05 & $5.5 \times 10^{-12}$ & 0.3 & 0.0357 & 0 & $9.8 \mathrm{~m} / \mathrm{s}^{2}$ & $0.01 \%$ & $7 \%$ & 36,500 & 259,200 & 1 & \\
\hline 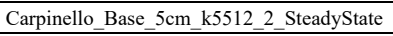 & base & $15 \mathrm{~cm} / \mathrm{yr}$ & 0.5 & 0.05 & $5.5 \times 10^{-12}$ & 0.3 & 0.0357 & 0 & $9.8 \mathrm{~m} / \mathrm{s}^{2}$ & $0.01 \%$ & $7 \%$ & 36,500 & 259,200 & 1 & \\
\hline Carpinello_Base_5cm_k5512_2_Inundation & base & $15 \mathrm{~cm} / \mathrm{yr}$ & 0.5 & 0.05 & $5.5 \times 10^{-12}$ & 0.3 & 0.0357 & 0 & $9.8 \mathrm{~m} / \mathrm{s}^{2}$ & $0.01 \%$ & $7 \%$ & 147 & 60 & 1.03 & $10 \mathrm{hr}$ \\
\hline Carpinello_Base_5cm_k5512_2_Recovery & base & $15 \mathrm{~cm} / \mathrm{yr}$ & 0.5 & 0.05 & $5.5 \times 10^{-12}$ & 0.3 & 0.0357 & 0 & $9.8 \mathrm{~m} / \mathrm{s}^{2}$ & $0.01 \%$ & $7 \%$ & 16,000 & 360 & 1.02 & \\
\hline Carpinello_Base_5cm_k12_1_SteadyState & base & $15 \mathrm{~cm} / \mathrm{yr}$ & 0.5 & 0.05 & $1.0 \times 10^{-12}$ & 0.3 & 0.0357 & 0 & $9.8 \mathrm{~m} / \mathrm{s}^{2}$ & $0.01 \%$ & $7 \%$ & 36,500 & 259,200 & 1 & \\
\hline Carpinello_Base $5 \mathrm{~cm} \_\mathrm{k} 12 \_2$ SteadyState & base & $15 \mathrm{~cm} / \mathrm{yr}$ & 0.5 & 0.05 & $1.0 \times 10^{-12}$ & 0.3 & 0.0357 & 0 & $9.8 \mathrm{~m} / \mathrm{s}^{2}$ & $0.01 \%$ & $7 \%$ & 36,500 & 259,200 & 1 & \\
\hline Carpinello_Base_5 $5 \mathrm{~cm} \_\mathrm{k} 12$ 2_Inundation & base & $15 \mathrm{~cm} / \mathrm{yr}$ & 0.5 & 0.05 & $1.0 \times 10^{-12}$ & 0.3 & 0.0357 & 0 & $9.8 \mathrm{~m} / \mathrm{s}^{2}$ & $0.01 \%$ & $7 \%$ & 147 & 60 & 1.03 & $10 \mathrm{hr}$ \\
\hline Carpinello_Base $5 \mathrm{~cm} \_\mathrm{k} 12$ 2_Recovery & base & $15 \mathrm{~cm} / \mathrm{yr}$ & 0.5 & 0.05 & $1.0 \times 10^{-12}$ & 0.3 & 0.0357 & 0 & $9.8 \mathrm{~m} / \mathrm{s}^{2}$ & $0.01 \%$ & $7 \%$ & 16,000 & 360 & 1.02 & \\
\hline
\end{tabular}

Table 7: Permeability Simulations 